NBER WORKING PAPER SERIES

\title{
THE ECONOMIC IMPACT OF SOCIAL TIES: EVIDENCE FROM GERMAN REUNIFICATION
}

\author{
Konrad B. Burchardi \\ Tarek Alexander Hassan \\ Working Paper 17186 \\ http://www.nber.org/papers/w17186
NATIONAL BUREAU OF ECONOMIC RESEARCH
1050 Massachusetts Avenue
Cambridge, MA 02138
June 2011

We are grateful to Philippe Aghion, Fernando Aragon, Oriana Bandiera, Tim Besley, Davide Cantoni, Wendy Carlin, Larry Katz, Yael Hochberg, Jason Garred, Maitreesh Ghatak, Claudia Goldin, Jennifer Hunt, Erik Hurst, Nathan Nunn, Rohini Pande, Torsten Persson, Michael Peters, Antoinette Schoar, Daniel Sturm, and Luigi Zingales. We also thank seminar participants at Harvard University, the University of Chicago, UCLA, the London School of Economics, London Business School, Northwestern, UBC, UPF, Bocconi, CEMFI, EBRD, Warwick, Namur, MPI Bonn, Carlos III, IIES Stockholm, TU Dresden, the Chicago Fed, and Dalhousie University, as well as at the NBER Summer Institute and the AEA, EFA, and EDP annual meetings for useful comments. All mistakes remain our own. The views expressed herein are those of the authors and do not necessarily reflect the views of the National Bureau of Economic Research.

NBER working papers are circulated for discussion and comment purposes. They have not been peerreviewed or been subject to the review by the NBER Board of Directors that accompanies official NBER publications.

(C) 2011 by Konrad B. Burchardi and Tarek Alexander Hassan. All rights reserved. Short sections of text, not to exceed two paragraphs, may be quoted without explicit permission provided that full credit, including $(\mathcal{C}$ notice, is given to the source. 
The Economic Impact of Social Ties: Evidence from German Reunification

Konrad B. Burchardi and Tarek Alexander Hassan

NBER Working Paper No. 17186

June 2011, Revised August 2012

JEL No. L14,O1,O11,O43,O52

\begin{abstract}
$\underline{\text { ABSTRACT }}$
We use the fall of the Berlin Wall in 1989 to show that personal relationships which individuals maintain for non-economic reasons can be an important determinant of regional economic growth. We show that West German households who have social ties to East Germany in 1989 experience a persistent rise in their personal incomes after the fall of the Berlin Wall. Moreover, the presence of these households significantly affects economic performance at the regional level: it increases the returns to entrepreneurial activity, the share of households who become entrepreneurs, and the likelihood that firms based within a given West German region invest in East Germany. As a result, West German regions which (for idiosyncratic reasons) have a high concentration of households with social ties to the East exhibit substantially higher growth in income per capita in the early 1990s. A one standard deviation rise in the share of households with social ties to East Germany in 1989 is associated with a 4.6 percentage point rise in income per capita over six years. We interpret our findings as evidence of a causal link between social ties and regional economic development.
\end{abstract}

Konrad B. Burchardi

konrad.burchardi@iies.su.se

Tarek Alexander Hassan

Booth School of Business

University of Chicago

5807 South Woodlawn Avenue

Chicago, IL 60637

and NBER

tarek.hassan@chicagobooth.edu 


\section{Introduction}

Economic sociologists argue that the economic success of any entity, be it an individual, a household, or a geographic region, depends on its position in the social structure of the marketplace. Well-connected individuals who bridge "holes" in this social structure are more likely to be economically successful and may generate a competitive advantage for the firms at which they work and the regions in which they live (Granovetter, 1985, 2005; Burt, 1992). Personal relationships which individuals maintain for non-economic reasons may thus be important determinants of economic development, both at the microeconomic and at the macroeconomic level.

Saxenian (1999) gives a striking example of this view. She analyzes the biographies of Indian engineers who migrated to California in the 1970s. Following the liberalization of the Indian economy in 1991 these immigrants were in a unique position to leverage their social ties to relatives and friends in Hyderabad and Bangalore. Many excelled in their personal careers, managing outsourcing operations for US firms. Saxenian argues that by connecting Silicon Valley firms to low-cost and high quality labor in their regions of origin, these Indian immigrants became instrumental in the emergence of their home regions as major hubs of the global IT services industry.

The work of economic sociologists thus raises a fundamental challenge to economists: Can the pattern of social ties between individuals determine the growth trajectory of entire regions?

While such a causal link between social ties and economic growth is consistent with a large class of models in which social ties provide 'social' collateral for economic transactions (Greif, 1993; Besley and Coate, 1995) or reduce informational frictions (Varian, 1990; Stiglitz, 1990), it has proven impossible to identify empirically.

The reason is that any empirical test of a causal link between social ties and aggregate economic outcomes faces a two-tiered reverse-causality problem. At the microeconomic level, individuals may form social ties as a result of economic interaction or in anticipation of future economic benefits. At the aggregate level, the regional distribution of social ties is a result of decisions of individuals about where to live, and these decisions are again endogenous to economic incentives (engineers do not randomly migrate to California). Identifying a causal link between social ties and aggregate economic outcomes thus requires (i) social ties that formed without regard to future economic benefits, and (ii) some exogenous variation in the regional distribution of these exogenously formed social ties. In general, and in the Indian example above in particular, such exogenous variation either does not exist or cannot be measured.

In this paper we argue that the fall of the Berlin Wall provides a unique historical setting 
which enables us to overcome both layers of reverse causality and to estimate the causal effect of social ties between individuals living in different regions on regional economic growth. In addition, we are able to trace this effect on regional economic growth to its microeconomic underpinnings by documenting a causal effect of social ties on entrepreneurial activity, on the investment behavior of firms, and on household income.

The first key advantage of this setting is the fact that the partition of Germany was generally believed to be permanent. After the physical separation of the two German states in 1961, private economic exchange between the two Germanies was impossible. West Germans maintaining social ties with East Germans during this period did so for purely non-economic reasons. After the fall of the Berlin Wall on November 9th 1989, trade between the two Germanies suddenly became feasible. To the extent that social ties facilitate economic exchange, social ties between West and East Germans thus unexpectedly took on economic value on the day of the fall of the Berlin Wall, which we are able to measure in the data. Indeed, West Germans who report to be in contact with friends or relatives in East Germany in 1989 experience a significant increase in the growth rate of their personal income after the fall of the Berlin Wall.

The second key advantage of the natural experiment surrounding the fall of the Berlin Wall is that the idiosyncrasies of Germany's post war history resulted in substantial variation across West German regions in the fraction of households with social ties to East Germany. In 1945 all German residents were expelled from Pomerania, Silesia, and East Prussia (which all became part of Poland and Russia) and allocated to the areas which would later become West and East Germany according to quotas fixed in the Potsdam Agreement. Between the founding of the East German state in 1949 and the construction of the Berlin Wall in 1961, the vast majority (2.8 million) of expellees allocated to East Germany migrated to the West after having lived in East Germany for up to 16 years. During the same period, an additional 3 million refugees who had lived in East Germany before World War II also fled to West Germany. We show that West German regions which received a large inflow of these two groups of migrants from East Germany (henceforth 'the East') have significantly stronger social ties to the East in 1989.

Of course, the assignment of migrants to West German regions might not be random, since individuals may have strategically settled in those regions in which they saw the best prospects for long-term economic growth. However, an overwhelming concern for those arriving from the East was an acute lack of housing. During World War II almost a third of the West German housing stock was destroyed. In some areas only 4.4\% of the housing stock that existed in 1939 was habitable in 1946. Variation in wartime destruction thus made it more difficult to settle in some parts of West Germany than in others at the time when millions of migrants arrived 
from the East. We argue that the extent of destruction in 1946 provides the exogenous source of variation in the regional distribution of social ties which we need in order to identify a causal effect of social ties on regional economic outcomes post 1989.

Using the degree of wartime destruction in 1946 as an instrument, we show a strong relationship between the share of migrants from the East settling in a given West German region, the share of households reporting to have social ties to the East in 1989, and changes in the growth rate of income per capita post 1989. A one standard deviation rise in the share of migrants from the East settling in a given West German region before 1961 is associated with a 4.1 percentage point rise in income per capita over the six years between 1989 and 1995.

The main identifying assumption for the causal interpretation of our region level results is that the degree of wartime destruction in 1945 (or any omitted factors driving it) affects changes in the growth rate of income per capita post 1989 only through its effect on the settlement of migrants from East Germany after World War II, and that the presence of these migrants indeed affects growth post 1989 exclusively due to their social ties to East Germany. We corroborate this identifying assumption in various ways. For example, we show that wartime destruction has no effect on the growth rate of income per capita in West German regions in the years before 1989. Moreover, we show that our results are particular to migrants arriving from East Germany and not to migrants arriving directly from the areas that became part of Poland and Russia.

In an effort to shed light on the mechanism linking social ties to regional economic growth, we trace the effects of social ties to the behavior of entrepreneurs and firms. While both entrepreneurs and non-entrepreneurs who live in regions with strong social ties to the East experience a rise in their incomes post 1989, the incomes of entrepreneurs increase at a significantly higher rate. Moreover, the share of the population engaged in entrepreneurial activity rises in regions with strong social ties to the East. Consistent with this increase in entrepreneurial activity, West German firms which are headquartered in regions with strong social ties to the East are more likely to invest in East Germany between 1989 and 2007. While social ties to the East predict investment in the East, they do not predict investment anywhere else in the world, except for a small effect on investment in Poland and the Czech Republic. This latter finding is notable as about half of those arriving in West Germany from East Germany before 1961 were expelled from areas in present-day Poland and the Czech Republic in 1945.

Using household level data, we show that individual households who have social ties to East Germany in 1989 internalize part of the income growth which they generate at the regional level. The income growth of households who have ties to at least one relative in the East is on average 6 percentage points higher in the six years following the fall of the Berlin Wall than that of 
comparable households who have no such ties.

We relate the effects of social ties on household and region level income growth using a structural model in which household income is a function of direct social ties to the East and indirect (higher-order) social ties to the East, where individual households may benefit from having friends who have ties to the East, even if they themselves have no such ties. Our preferred estimates imply that, other things equal, a direct social tie to the East has the same effect on individual household income as a 49.3 percentage point (or 3.5 standard deviation) increase in the regional share of households who have such ties. From the perspective of an individual household, the incremental benefit from a direct social tie to the East is thus large compared to the incremental benefit from higher-order social interaction. Nevertheless, indirect social ties to the East account for two thirds of the aggregate effect because all of a regions households benefit from indirect social ties, while only a subset of the population benefits from direct social ties.

We believe the most plausible interpretation of our results is that West German households which had direct or indirect social ties to East Germany in 1989 had a comparative advantage in seizing the new economic opportunities in the East. Having personal relationships with East Germans may have given them access to valuable information about local demand conditions or about the quality of East German assets that were offered to investors. (Almost the entire East German capital stock was sold to private investors between 1990 and 1994.) This comparative advantage resulted in a persistent rise in their household incomes but also appears to have generated growth in income per capita and increased returns to entrepreneurial activity at the regional level. Part of this effect on regional economic performance may be explained if firms owned by a household with social ties to the East (or firms with access to a local labor force with such ties) had a comparative advantage in investing in East Germany.

A large literature shows that measures of affinity between regions, such as trust, telephone volume, and patterns of historical migration, correlate strongly with aggregate economic outcomes, such as foreign direct investment (Guiso et al., 2009), international asset flows (Portes and Rey, 2005), and trade (Rauch and Trindade, 2002). Relative to this literature we innovate in three dimensions. First, we are able to establish causation rather than correlation. Second, we are able to examine economic growth as an outcome variable directly; and third, we are able to tie our aggregate measure of affinity directly to individual level data about personal relationships within an environment in which we can exclude differences in preferences, culture, and language as alternative explanations with a high degree of certainty. Our work thus provides evidence that social ties between individuals can causally affect macroeconomic outcomes, which is a link that 
is implicit in a wide range of models that feature network-based economic interaction. ${ }^{1}$

By tracing the effect of social ties on regional economic growth to household income, entrepreneurial activity, and firm investment, our paper also provides evidence on the microeconomic channels through which social ties may affect economic growth. In this sense our results relate to a large literature which links social networks and social ties to a broad set of microeconomic outcomes. ${ }^{2}$

As the patterns of social ties which we identify in our analysis are driven by an internal migration post World War II, our paper also relates to a large literature on the economic effects of migration (e.g. Friedberg (2001)). We add to this literature by providing evidence of a distinct channel through which large-scale migration may affect long-run economic growth.

Other papers have used German reunification as a testing ground for economic theory. Most closely related are Redding and Sturm (2008) who estimate the importance of market access for economic development. ${ }^{3}$

The following section summarizes the relevant history of post war Germany. Section 3 discusses the data and its construction. Section 4 identifies the effect of social ties on regional economic growth. Section 5 traces this effect to the effect of social ties on entrepreneurial activity and firm investment. Section 6 analyzes the effect of direct and indirect social ties using household level data. Section 7 concludes. The online appendix contains additional robustness checks and details on the construction of our dataset.

\section{Historical Background}

\subsection{Destruction of Housing Stock during World War II}

German cities and towns were heavily destroyed after World War II. This was mainly the result of allied air raids, which began in 1940 and intensified until the final days of the war in 1945. They left around 500,000 dead and resulted in the destruction of a third of the West German housing stock, making it the most devastating episode of air warfare in history. ${ }^{4}$

In the early days of the war the Royal Air Force attempted to slow down the advance of the

\footnotetext{
${ }^{1}$ See for example Rauch (1999), Kranton and Minehart (2001), Calvo-Armengol and Jackson (2004), Karlan et al. (2009), Ambrus, Möbius, and Szeidl (2010), Chaney (2011), and Jackson et al. (2011).

${ }^{2}$ These range from education (Sacerdote (2001)) and employment (Munshi (2003)) to performance in the financial industry (Cohen et al. (2008)) and agricultural yields (Conley and Udry (2010)). Also see Bertrand et al. (2000), Hochberg et al. (2007), Beaman (2012), Kuhnen (2009), Shue (2011), and Banerjee et al. (2012).

${ }^{3}$ Also see Alesina and Fuchs-Schündeln (2007), Fuchs-Schündeln and Schündeln (2005), Bursztyn and Cantoni (2009) and Ahfeldt et al. (2010).

${ }^{4}$ The information presented in this section is from USGPO (1945), Kurowski (1977), and Friedrich (2002).
} 
German army into the Soviet Union by destroying transport infrastructure. This strategy failed and was quickly abandoned, as the technology available at the time did not permit targeted raids. At best, the pilots flying the nighttime raids were able to make out that they were above a city (and they were often even unsure which city lay below). This led to the adoption of the doctrines of 'morale bombing' (1941) and of 'fire and carpet bombing', which aimed at destroying the German morale by destroying cities and towns (Kurowski, 1977). By the end of the war, $50 \%$ of the 900,000 metric tons of bombs had hit residential areas, while $17 \%$ had hit industry or infrastructure.

The most heavily-damaged cities during the early years of the war were those that were close to the British shore and easy to spot from the air, e.g. Hamburg and Cologne. After 1944, the Allies used recent technological advances to implement fire storms, which were easiest to create in cities with highly flammable, historical centers, such as Darmstadt, Dresden, and Würzburg. Fire storms could typically not be implemented in cities which had already been hit by a large number of explosive bombs, as the rubble from earlier raids would prevent the fire from spreading. This is why the cities that were attacked late in the war (often strategically the least important) were among the most heavily destroyed. ${ }^{5}$

Figure 1 shows the varying intensity of destruction in West German regions. Note that none of our empirical results rely on this pattern being random or driven by specific factors. Instead, our identification strategy relies on the assumption that the pattern of wartime destruction, or any omitted variables driving it, have no direct effect on changes in growth rates of West German regions 45 years later, post 1989.

\subsection{The Partition and Reunification of Germany}

In 1944, as World War II entered its final phase, the UK, the US, and the Soviet Union agreed on a protocol for the partition of pre war Germany: the areas to the east of the rivers Oder and Neisse (Pomerania, Silesia, and East Prussia) were to be annexed by Poland and by the Soviet Union, and the remaining territory was to be divided into three sectors of roughly equal population size. The UK would occupy the Northwest, the US the South, and the Soviet Union the East. The capital, Berlin, would be jointly occupied. At the end of the war, the three armies took control of their sectors, and the US and Britain carved a small French sector out of their territory. In 1949, with the onset of the Cold War, the three Western sectors formed the Federal Republic of Germany (West Germany), and the Soviet sector became the German Democratic Republic

\footnotetext{
${ }^{5}$ During a fire storm, a large section of a city catches fire, creating winds of up to 75 meters per second, depriving those exposed of oxygen and often sucking them into the fire.
} 
(East Germany). Economic exchange between the two parts of Germany became increasingly difficult as the East German government rapidly introduced central planning. In 1952 the border was completely sealed, cutting any remaining legal or illegal trade links between East and West. ${ }^{6}$

Until the construction of the Berlin Wall in August 1961, there remained the possibility of personal transit from East to West Berlin, which was the last remaining outlet for East Germans to flee to West Germany. After 1961, migration between East and West virtually ceased. In the following years the partition of Germany was formally recognized in various international treaties and was, until the late summer of 1989, generally believed to be permanent. ${ }^{7}$

In September of 1989, it became apparent that a critical mass of East Germans had become alienated from the socialist state, its declining economic performance, and the restrictions it placed on personal freedom. Increasingly large public demonstrations led to the opening of the Berlin Wall on November 9th, 1989. The first free elections in East Germany were held in March of 1990, followed by the rapid political, monetary, and economic union between East and West Germany by the end of the same year.

\subsection{Refugees and Expellees in West Germany, 1945-1961}

In 1945 the Polish and Soviet authorities expelled all German nationals from annexed territory so that these areas could be inhabited by Polish (and Soviet) nationals. Those that did not leave on their own accord (many had fled the advancing Soviet army in the final months of the war) were marched or transported towards the four sectors. We refer to former residents of the annexed territory as 'expellees' (Vertriebene). Ethnic Germans that either originally lived in or moved to the countries occupied by the German army during war were also expelled in many cases, particularly from Czechoslovakia, Hungary, Romania, and Yugoslavia. Expellees were registered and then assigned to one of the four sectors, according to quotas fixed in the Potsdam Agreement. ${ }^{8}$ The authorities of the sectors in turn allocated the expellees to the states within their jurisdictions and assigned them quarters wherever they could find intact housing stock.

\footnotetext{
${ }^{6}$ Throughout the period gift giving remained possible and West Germans often sent packages to East Germans. However, the only remaining trade between the two countries was the 'Interzonenhandel' which was a system of barter transactions between the two governments. In 1960 its total volume came to the equivalent of $\$ 178 \mathrm{~m}$. See Holbik and Myers (1964) for a detailed description of the Interzonenhandel.

'The most important of these treaties was the 'Grundlagenvertrag' of December 1972 between East and West Germany in which both countries recognized ‘two German states in one German nation'. Following this treaty East and West Germany were accepted as full members of the United Nations.

${ }^{8}$ The official plan adopted by the allies in November 1945 was to expel 6.65 million Germans. 2.75 million were to be allocated to the Soviet sector and 2.25 million, 1.5 million, and 0.15 million to the American, British, and French sectors, respectively (Bethlehem, 1982, p.29). Although the initial phase of expulsion was often chaotic the quotas fixed in the Potsdam Agreement were largely enforced ex-post (Frank, 2007).
} 
The first wave of 5.96 million expellees arrived in the three Western sectors by 1946 . We refer to this group as 'direct expellees'. As it became increasingly apparent that the division of Germany would become permanent, most of the expellees that had originally been allocated to the Soviet sector (2.8 million) also left for the West. These 'expellees via the Soviet sector' are critical to our empirical analysis as they lived in East Germany for up to 16 years before migrating to West Germany and thus had the opportunity to form social ties to East Germans. By 1960, the total number of expellees in West Germany had risen to 9.0 million, of which roughly one third were expellees via the Soviet sector. ${ }^{9}$

In parallel, an increasing number of native residents of the Soviet sector who were dissatisfied with the political and economic prospects of the fledging East Germany fled to the West. This flow of 'refugees' (Flüchtlinge) peaked in the years before the construction of the Berlin Wall, with on average around 300,000 individuals illegally crossing the border in each year between 1957 and 1961 (Hunt, 2006). By 1961, three million East German refugees settled in the West.

While the occupying authorities in the western sectors, and later the West German authorities, had an explicit policy of supplying expellees with housing and various subsidies, there was little support for refugees. In fact, as late as 1950 the authorities actively tried to discourage refugees from entering West Germany on the grounds that they would exacerbate an already catastrophic housing situation and in fear of the political consequences of de-populating East Germany. However, the authorities never attempted to deport refugees back to the East, and so refugees often made their own way in West Germany without registering with the authorities (Bethlehem, 1982, chapter 3). The severe housing crisis that resulted from the inflow of millions of migrants into the heavily destroyed Western sectors remained a principal determinant of the allocation of expellees and refugees to West German cities and towns until the late 1950s. ${ }^{10}$

\section{The Data}

We use data at the household, firm, district (Landkreis), and regional (Raumordnungseinheit) level. Districts are the equivalent of US counties. Regions are the union of several districts,

\footnotetext{
${ }^{9}$ We are unable to determine exactly how many expellees remained in East Germany, as the communist government declared after 1950 that the expellees had been fully integrated into East German society and banned the concept from subsequent government statistics (Franzen, 2001).

${ }^{10}$ In 1955 the total stock of apartments was still $30 \%$ below its 1939 level, which was reached only in the late 1960s (Sensch, 2010). In the 1940s the availability of housing was the principal determinant of where the expellees were assigned quarters. After 1949 economic considerations started playing a more important role in the allocation process and the West German government also initiated a number of programs encouraging migration to areas in which there was a relatively high demand for labor. However, these programs remained relatively limited, with less than one in ten expellees participating (Bethlehem, 1982, p. 29, pp.49).
} 
and each district belongs to one such unit. Regions do not have a political function but exist exclusively for statistical purposes. ${ }^{11}$ Most of our aggregate data is available at the district level, except for data on income per capita and employment before 1995, which is available only at the regional level. Our primary units of analysis are the 75 West German regions, of which we drop three for which we have no information on wartime destruction. We also drop Berlin due to its unique position and historical circumstances as well as Hamburg which is the only federal state that has no regional subdivisions. When we use aggregate controls in our firm- and household-level analysis we always use data at the lowest level of aggregation available.

\subsection{Region Level Data}

The 1961 census reports the number of inhabitants and the number of expellees in each West German district. The census presents the data separately for expellees who arrived directly in West Germany during or after the war and for expellees who arrived in West Germany after having registered a residence in the Soviet sector. From these data we created the variables Share Expellees (Direct) '61 and Share Expellees (Sov. Sector) '61. ${ }^{12}$ By contrast, we do not have reliable regional data on the settlement of refugees arriving from the Soviet sector as refugees had little incentive to reveal themselves to the authorities. However, since expellees via the Soviet sector arrived in West Germany around the same time as refugees and since both groups faced similar constraints regarding the shortage of housing, the settlement pattern of refugees across West German regions was likely very similar to that of expellees arriving from the Soviet sector. We therefore use Share Expellees (Sov. Sector) '61 as our primary proxy for the intensity of social ties to the East in a given West German region. Appendix Figure 1 shows the distribution of this group across West German regions in 1961.

For our instrumental variables strategy we coded two measures of wartime destruction: the share of dwellings that were destroyed in 1946, labeled Share Housing Destroyed '46, and the amount of rubble in cubic meters per inhabitant, labeled Rubble ' 46 ( $m^{3}$ p.c.). Our data source reports both measures for the 199 largest West German cities and towns that collectively accounted for $47 \%$ of the total pre-war population of West Germany. We also coded the number of inhabitants of these towns in 1939 and 1946 from the same source. We aggregated the data on wartime destruction by calculating the mean destruction across cities and towns in a district or region, weighted by population in 1939. (See Appendix Table 1 for details.)

\footnotetext{
${ }^{11}$ In this sense they are analogous to metropolitan statistical areas in the US, but they also include rural areas.

${ }^{12}$ These data were collected at the district level. Some West German district boundaries changed between 1961 and 1989. In those cases we used area weights calculated in ArcGIS to convert 1961 districts into their 1989 equivalents.
} 
Our data on income per capita are from the German Mikrozensus, an annual, obligatory random survey of one percent of the population. The survey lists an income bracket for each individual, which we aggregate to the region level using the mean of each bracket. Income per capita at time $t$ is labeled Income $t$ (p.c.), where $t$ is every second year between 1985 and 1995 . As the Mikrozensus does not identify districts prior to 1995, an aggregation to districts was not possible. We also used the Mikrozensus to construct the average income of entrepreneurs ( Income Entrepreneurs $t$ (p.c.)), the average income of non-entrepreneurs (Income Non-Entrepreneurs $t$ (p.c.)), as well as the share of entrepreneurs amongst the respondents (Share Entrepreneurs $t$ ) for each region. From the same source we obtained data on the share of the population working in different sectors $s$ of the economy in 1989 (Share Employed in s '89), where $s$ stands for agriculture; manufacturing; services; and government, respectively, the share of the region's population that are migrants arriving from the East in the years following fall of the Berlin Wall (Migration from East '91-'95), and further variables described in Appendix Table 1. As an additional control we calculated the distance of the center of each district or region to the former inner-German border using GIS data (Distance to East $(100 \mathrm{~km})$ ).

\subsection{Firm-Level Data}

Our firm-level data is from the 2007 edition of the ORBIS dataset, which is the edition that expands coverage to small and medium sized German firms. It includes information on the location of the headquarters of each West German firm and a list of its subsidiaries and branches. We use the postal code to match each firm to the district in which its headquarters is located. After dropping firms based in districts for which we lack data on wartime destruction we are left with data on 19,387 firms which have at least one subsidiary or branch in West Germany outside of the district of their headquarters. ${ }^{13}$ As a simple measure of firms' investment activity in different parts of the world, we created a dummy variable for whether the firm has a subsidiary or branch in a given location $x(S$. \& B . in $x$ (Dummy)). We calculated this dummy variable for 'East Germany', 'Poland and Czech Republic', the 'Old EU Countries' (the 14 EU member countries other than Germany prior to enlargement in 2004), the 'New EU Countries (excluding Poland and Cz. Republic)' (all EU member countries that acceded in or after 2004), and for 'Non-EU Countries'. For the same set of firms we computed the share of each firm's subsidiaries and branches in location $x$ as a fraction of its total number of subsidiaries and branches in location $x$ and West Germany (Share of Total S. \& B . in $x$ ). As proxy for the size of the firm

\footnotetext{
${ }^{13}$ We exclude firms that have only one address. Since our inference uses only a single cross-section, these firms are uninteresting as the probability that they own a subsidiary or branch in the East is mechanically zero.
} 
we use the log of the number of subsidiaries and branches it operates in West Germany ( $S$. $\mathscr{G} B$. in West Germany). Finally, we used the NACE code given in the ORBIS dataset to define four sectoral fixed effects (agriculture, manufacturing, services, and government).

\subsection{Household Level Data}

Our household level data is from the German Socio-Economic Panel (SOEP), which is an annual panel of German households. From the panel, we selected all West German households (again excluding Berlin) which participated in the 1985, 1989, and 1995 waves. For each of these households we use information on household income in the years 1985-2001 (Income (SOEP)) and information on 29 other socio-economic characteristics of the household, including age, education, occupation and social status of the household head as well as the composition of household income, transfers to and from relatives, and asset holdings. We also created a dummy variable which is one if any household member has lived in East Germany prior to 1961 (Lived in East Germany). ${ }^{14}$

Importantly, the 1991 wave of the panel contains several questions about contacts to friends and family in East Germany. Since the survey was conducted in the second year after the fall of the Berlin Wall and households had some time to renew ties with individuals in the other part of Germany, we choose not to rely on information about the intensity of contact to friends and relatives, although it is available. ${ }^{15}$ Instead, we base our work on the response to the simple factual question "Do you have relatives in East Germany?" and generate a dummy variable that is one if at least one member of the household responded with 'yes', and zero otherwise ( Ties to Relatives '91). We also aggregated this variable to the region level by calculating the share of households with ties to East Germany in each West German region (Share Ties to Relatives '91), which we use as a secondary measure of the intensity of social ties at the regional level. A possible source of measurement error is that West German relatives of the survey respondents may have migrated to East Germany directly after the fall of the Berlin Wall and before the conclusion of the 1991 wave of the survey. However, the flow of migrants from West to East in 1990 was small (only around 30,000 individuals, Hunt (2006)). It is thus safe to assume that households which were based in West Germany in 1989 and reported a relative in East Germany in 1991 also had a relative in East Germany in 1989.

\footnotetext{
${ }^{14}$ Details of how we aggregated data on individuals to the household level are given in Appendix Table 1.

${ }^{15}$ Our results are very similar if we use information on friendships or condition on respondents indicating 'close' ties to their relatives or friends.
} 


\subsection{Descriptive Statistics}

Panel A of Table 1 presents the data on West German regions; column 1 gives the data for all regions, columns 2 and 3 divide the sample into regions with a higher and lower share of housing destroyed in 1946 than the median region. The first row of column 1 gives the mean and the standard deviation of the share of expellees via the Soviet sector in 1961. On average, Expellees via the Soviet sector made up $4.8 \%$ of the 1961 population. Similarly, expellees that came directly to West Germany on average made up $12.0 \%$ of the population in 1961 (row 2), and $29.7 \%$ of the 1991 population reported having relatives in East Germany (row 3). In all three cases, these shares are higher in regions that suffered lower levels of wartime destruction. The variation in wartime destruction is considerable, with $14.9 \%$ of housing on average destroyed in regions with low destruction and $48.7 \%$ in regions with high destruction (row 4). Moreover, regions which are closer to the inner-German border tended to be less destroyed than those that are further away (row 6). The pattern in income per capita is interesting: while regions with lower wartime destruction are slightly poorer in 1985 and 1989, they are slightly richer than the average region in 1995 .

Panel B of Table 1 presents the data on West German firms in 2007, again split up by regions with above and below the median level of wartime destruction. On average, firms in regions with lower wartime destruction are slightly smaller as measured by the number of subsidiaries they operate in West Germany (row 1). Nevertheless they are also more likely to operate a subsidiary or branch in the East (8.3\% versus $7.2 \%$ ). On average, $7.8 \%$ of the firms in our sample operate a subsidiary or a branch in East Germany (row 3) and 1.0\% operate in non-EU countries.

\section{Social Ties and Regional Economic Growth}

We first explore the effect of social ties between West and East Germans on income growth in West German regions. The structural equation of interest is

$$
Y_{r}^{95}-Y_{r}^{89}=\alpha T_{r}^{89}+\phi Y_{r}^{89}+\mathbf{Z}_{r}^{\prime} \zeta+\varepsilon_{r}
$$

where $Y_{r}^{t}$ is $\log$ income per capita in region $r$ in year $t$. The left hand side variable is thus the growth in income per capita between 1989 and 1995. $T_{r}^{89}$ denotes our measure of social ties in region $r$, which for our key results is the share of the region population who are expellees via the Soviet sector. $\mathbf{Z}_{r}$ is a vector of controls which always contains a complete set of state fixed effects and the distance from region $r$ to the inner-German border. The coefficient of interest is $\alpha$, which 
measures the effect of social ties on growth in income per capita after 1989. In all specifications we control for income per capita in 1989. The coefficient $\phi$ thus measures the degree of mean reversion in income per capita between West German regions. In our standard specification we also control for the pre-existing growth trend by including the growth rate of income per capita between 1985 and 1989, $Y_{r}^{89}-Y_{r}^{85}$. The coefficient $\alpha$ then estimates the differential change in the growth rate of income per capita after 1989 for regions with different intensities of social ties to the East. The assumption that the relationship between growth in income per capita and social ties is linear is made for simplicity. The error term $\varepsilon_{r}$ captures all omitted influences, including any deviations from linearity. Throughout, standard errors are calculated using the Huber-White correction to ensure robustness against arbitrary heteroscedasticity. ${ }^{16}$

Equation (1) will consistently estimate the parameter of interest if $\operatorname{Cov}\left(T_{r}^{89}, \varepsilon_{r}\right)=0$. This covariance restriction may however not hold in the data, since the settlement of migrants from the East in West Germany prior to 1961 (and thus the strength of social ties to East Germany) may be correlated with differences in growth prospects across regions. Although we show ordinary least squares estimates of equation (1) for reference and comparison, we primarily rely on an instrumental variables strategy, which uses only the variation in $T_{r}^{89}$ that is attributable to variation in wartime destruction across regions in 1946. Our first stage specification is

$$
T_{r}^{89}=\gamma W_{r}^{46}+\phi^{f s} Y_{r}^{89}+\mathbf{Z}_{r}^{\prime} \zeta^{f s}+\nu_{r}
$$

where $W_{r}$ is our measure of wartime destruction and (2) contains the same covariates as (1). Our key identifying assumption is that $\operatorname{Cov}\left(W_{r}^{46}, \varepsilon_{r}\right)=0$. It states that, conditional on the covariates we control for, (i) there is no omitted variable which drives both wartime destruction and differential changes in income growth post 1989 and (ii) wartime destruction in 1946 has no effect on changes in the growth rate of income per capita after 1989 other than through its effect on the settlement of migrants who have social ties to the East.

\subsection{The First Stage Relationship}

Panel A of Table 2 shows our basic first stage regressions, using the share of expellees via the Soviet sector in 1961 as a proxy for social ties in 1989. Column 1 is the most parsimonious specification as shown in equation (2). It regresses the share of expellees via the Soviet sector on the share of housing destroyed in 1946, while controlling for the distance to the inner-German

\footnotetext{
${ }^{16}$ Since there are only 9 states (our sample excludes Berlin and Hamburg) we do not cluster the standard errors at the state level.
} 
border, for income per capita in 1989, and for state fixed effects. The coefficient estimate of -0.019 (s.e. $=0.004$ ) is statistically significant at the $1 \%$ level and suggests that a one standard deviation increase in the share of housing destroyed in 1945 (s.d. $=0.21$ ) is associated with a 0.4 percentage point drop in the share of expellees via the Soviet sector in 1961. ${ }^{17}$ (This corresponds to $8 \%$ fewer expellees via the Soviet sector relative to the mean across regions.)

As expected, the share of expellees in 1961 falls with the distance to the inner-German border. The coefficient on income in 1989 is positive and significant, suggesting that expellees tended to settle in regions that were richer in 1989, which is most likely attributable to persistent differences in income per capita between regions which predate $1961 .^{18}$

The specification in column 2 is our standard specification. It adds income growth in the five years prior to 1989 as an additional control. The coefficient of interest remains virtually unchanged at -0.020 (s.e. $=0.004$ ). The coefficient on income growth is statistically indistinguishable from zero at conventional significance levels, suggesting that the pattern of settlement of expellees via the Soviet sector in 1961 is not correlated with income growth in the years prior to the fall of the Berlin Wall.

Figure 2 plots the conditional relationship estimated in this column and shows that the first stage relationship is not driven by outliers. Columns 3-6 of Panel A of Table 2 show the first stage regressions corresponding to robustness checks which we perform in the instrumental variables estimation. In column 3 we use the volume of rubble per capita in 1946 as an alternative measure of wartime destruction, which again yields a negative and significant coefficient. In column 4 we replace our control for the distance to the inner-German border with a fixed effect for each distance quartile and in column 5 we add the share of the workforce employed in agriculture, manufacturing, services, and government in 1989 (we do not report the coefficients on these variables to save space). Finally, column 6 adds the extent of migration after reunification as an additional control. In each case the coefficient of interest remains virtually unchanged and statistically significant at the $1 \%$ level.

Panel B of Table 2 repeats the same specifications as in Panel A, using the share of households with ties to relatives in East Germany in 1991 as an alternative proxy for social ties in 1989. In the interest of preserving space the panel shows only the coefficient of interest. All estimates are negative and all except the ones in columns 3 and 4 are statistically significant at the $5 \%$ level

\footnotetext{
${ }^{17}$ The share of expellees via the Soviet sector proxies for both groups of migrants (expellees and refugees) arriving from East Germany. Since both groups were roughly of the same size we may speculate that a one standard deviation increase in wartime destruction may be associated with a drop in the total share of migrants from the East settling in a given West German region which is around twice as large.

${ }^{18}$ Income per capita in 1989 and other control variables are included in all specifications to present the first stage corresponding to the instrumental variables results discussed below.
} 
(the latter is significant at 10\%). The coefficient in column 1 is -0.139 (s.e. $=0.061$ ). It implies that a one standard deviation rise in the share of housing destroyed in 1945 is associated with a 2.92 percentage point drop (or alternatively a $9.8 \%$ drop relative to the average) in the share of households that have a relative in East Germany in 1991. Similar results (not shown) hold for the share of households that report contact with friends in East Germany.

When we regress the share of households with ties to the East in 1991 on the share expellees via the Soviet sector as instrumented with the share of housing destroyed in 1946 and our standard control variables the coefficient of interest is 7.229 (s.e.=3.243), suggesting that regions which suffered worse destruction during World War II have proportionately more households with ties to the East in 1991 because they received more migration from the East before 1961.

In the following sections we use the share of expellees via the Soviet sector in 1961 as our main proxy for social ties to the East. Since it lays bare the historical source of variation it allows us to perform a number of placebo experiments corroborating our key identifying assumption. We present corresponding results using the share of households with ties to the East in 1991 when we trace the effect on regional income growth to the household level in section 6 . The two proxies are highly correlated (0.627), as shown in Appendix Figure 2, and yield quantitatively almost identical results, although standard errors tend to be narrower when we use the census-based data on expellees which are likely measured with less error.

\subsection{The Reduced Form Relationship}

As a prelude to our instrumental variables estimates, Panel C shows the reduced form relationship between growth in income per capita after the fall of the Berlin Wall and wartime destruction. All specifications (except the one in column 3) are again identical to the ones in Panels A and B, with the left hand side variable now being the growth in income per capita between 1989 and 1995, $Y_{r}^{95}-Y_{r}^{89}$. The coefficient of interest is negative and statistically significant at the $5 \%$ level in all columns. The estimate in column $2(-0.048$, s.e. $=0.020)$, suggests that regions which were least destroyed during the war experienced a significantly higher increase in the growth rate of income per capita post 1989 than regions which were most destroyed during the war. A one standard deviation drop in the share of housing destroyed is associated with a 1 percentage point higher growth in income per capita over the six years following 1989. The size of the estimated coefficient is stable across columns 1,2 and 4-6. Appendix Figure 3 depicts this relationship graphically in a conditional scatter plot corresponding to the estimate in column $2 .{ }^{19}$

\footnotetext{
${ }^{19}$ In the plot, Wilhelmshaven looks like a significant outlier. Dropping Wilhelmshaven from the sample reduces the coefficient estimate to -0.033 (s.e. $=0.016$ ). As a more systematic check for the effect of outliers, we run a
} 
As a first test of the mechanism by which wartime destruction could suddenly affect economic growth 45 years after the fact, the specification in column 3 includes both the share of housing destroyed in 1946 and rubble per capita in 1946. The results are encouraging for our identification strategy: while the coefficient on the share of housing destroyed remains negative and significant at -0.060 (s.e. $=0.027$ ), the coefficient on rubble per capita is positive and insignificant. This pattern is consistent with the view that it is primarily the lack of housing in 1946 and not wartime destruction per se that affects changes in economic growth post 1989.

\subsection{Instrumental Variables Results}

In our instrumental variables estimation we explicitly test the hypothesis that a concentration of households with social ties to East Germany in 1989 in a given West German region is causally related to a rise in the growth rate of income per capita after the fall of the Berlin Wall. In Table 3, we estimate (1) using only the variation in social ties in 1989 that is due to variation in wartime destruction by instrumenting for the share of expellees via the Soviet sector in 1961. In column 1 we instrument with the share of housing destroyed in $1946 .{ }^{20}$ The coefficient estimate on the share of expellees is 2.169 (s.e. $=0.940$ ), suggesting that a one standard deviation increase in the share of expellees in 1961 (s.d. $=0.019)$ is associated with a 4.1 percentage point rise in income per capita over the six years following 1989 (or roughly a 0.7 percentage point higher growth rate per annum). ${ }^{21}$ The coefficient on income in the base year, 1989, is negative and significant, which suggests mean reversion in income per capita across West German regions. Somewhat surprisingly, the coefficient on the distance to the inner-German border is positive, which suggests that the regions closest to the inner-German border did not immediately profit from the opening of the border (which is in line with a similar observation in Redding and Sturm (2008) that the population of West German cities close to the inner-German border grew relatively little between 1989 and 2002). ${ }^{22}$

robust regression (according to the terminology used by STATA) in which observations with a Cook's D value of more than one are dropped and weights are iteratively calculated based on the residuals of a weighted least squares regression. The robust estimate is -0.032 (s.e. $=0.014)$.

${ }^{20}$ The F-statistic against the null that the excluded instrument is irrelevant in the first-stage regression is 18.92. Using both measures of wartime destruction as instruments for Share Expellees (Sov. S), the Hansen $\mathrm{J}$ test statistic for overidentifcation is 0.460 with a p-value of 0.498 . We thus fail to reject the null that our instruments are uncorrelated with the error term and correctly excluded from the second stage regression.

${ }^{21}$ Since our model contains a lagged dependent variable there may be a mechanical bias in the coefficient of interest. Instrumenting the lagged dependent variable with its own lag ensures consistency (Anderson and Hsiao, 1982). If we use log of income in 1985 and $\log$ of income in 1982 as instruments for log of income growth between 1985 and 1989 the coefficient estimate increases to 3.204 (s.e.=0.998) and is significant at the $1 \%$ level.

${ }^{22}$ All region level results are robust to various parametric and non-parametric ways of controlling for the distance to the inner-German border. 
Column 3 gives our standard specification in which we control both for the level of income in 1989 and for income growth in the four years preceding 1989. The coefficient of interest rises slightly to $2.442($ s.e. $=0.874)$ and is significant at the $1 \%$ level. Regions which received a larger share of migrants from the East prior to 1961 thus experienced a significant increase in their growth rate of income per capita post 1989.

The results of column 3 are almost unchanged when we simultaneously instrument the share of expellees with both the share of housing destroyed and with rubble per capita (shown in column 4). Column 2 shows the OLS estimate of our standard specification for comparison. It is only about one half of a standard error lower at 1.963 (s.e.=0.570), suggesting that the endogenous assignment of expellees to West German regions induces only a relatively mild downward bias in the OLS estimate. A Hausman test fails to reject the null hypothesis that $\operatorname{Cov}\left(T_{r}^{89}, \varepsilon_{r}\right)=0$.

\subsection{Validity of the Exclusion Restriction}

While the endogenous assignment of migrants from the East to West German regions does not seem to have a large impact on our results, our identifying assumption, that the degree of wartime destruction in 1946 affected changes in the growth rate of income per capita after 1989 only through its effect on the settlement of migrants and their social ties to the East, cannot be tested directly. Nevertheless, we can perform a number of falsification exercises to assess its plausibility. There are two types of potential challenges and corresponding tests.

Simple Challenge The 'simple' challenge to our identifying assumption is that wartime destruction (or an omitted variable driving it) may have had a lasting effect on income growth in West German regions which persisted for more than half a century (until 1995). We believe that we can discard this concern.

First, our standard specification controls for the growth rate of income pre 1989 and thus identifies changes in the growth rate of income per capita that occur after 1989.

Second, we can show that growth in income per capita in the years prior to 1989 is uncorrelated with wartime destruction and with the settlement of expellees. Panel B of Table 3 shows a placebo experiment in which we use income growth between 1985 and 1989 as the dependent variable rather than as a control. All specifications are parallel to those in Panel A (except that we now control for log income per capita in 1985 rather than in 1989). Throughout the panel the coefficient of interest is statistically indistinguishable from zero. The same is true when we use the growth rate of income per capita between 1982 and 1989 as dependent variable (not shown). 
Wartime destruction thus becomes relevant for economic growth only post $1989 .{ }^{23}$

Third, while we have no data on regional income per capita prior to 1982, it is a well documented fact that wartime destruction had no impact on population growth in West German cities post 1960 (Brakman et al., 2004). In Figure 3 we replicate part of this result. The figure depicts coefficient estimates from city-level regressions of population growth in the years between 1929 and 2000 on the share of housing destroyed in 1946 and a constant. Not surprisingly, wartime destruction had a strong and significantly negative effect on population growth during the war (between 1939 and 1945). During the period of reconstruction, between 1946 and 1960, the cities most heavily destroyed grew fastest. However, from 1960 onwards there is no statistically significant effect of wartime destruction on population growth and the coefficient estimates are virtually zero (albeit with a large standard error in 1960). To the extent that population growth proxies for income growth, this result suggests that the direct effect of wartime destruction on income growth was short-lasting. ${ }^{24}$

Sophisticated Challenge The 'sophisticated' challenge to our identifying assumption is that the pattern of wartime destruction (or some omitted variable driving it) may have affected income growth through some other channel which only 'switched on' post 1989.

For example, the allies may have targeted areas which were focused on manufacturing and the manufacturing sector may have experienced a relative decline after 1989. However, when we control for the sectoral composition of the workforce in column 6 of Table 3 the coefficient of interest changes very little to 2.772 (s.e.=0.848). The estimated coefficient on the share of the workforce employed in manufacturing is negative, but it is not statistically significant. Any variation in income growth post 1989 due to a relative decline of the manufacturing sector is thus unrelated to the effect we identify.

More generally, we find no evidence that wartime destruction is associated with any particular socio-economic characteristics in 1989. Conditional on our standard control variables, there are no statistically significant differences between regions with higher and lower levels wartime destruction in the sectoral composition of the workforce, educational attainment, unemployment, or the share of the population engaging in entrepreneurial activity (see Appendix Table 4a ).

Another potential concern is that after 1989 highly skilled workers from East Germany may

\footnotetext{
${ }^{23}$ In Appendix Table 2 we pinpoint the timing of the effect at a higher frequency by regressing log income per capita for each region and year post 1985 on the interaction of year fixed effects with the share of expellees in 1961 (again instrumented with wartime destruction). The table shows no effect of the settlement of expellees on income growth rates prior to 1989, a positive effect in all years post 1989 and a statistically significant effect on growth between 1989 and 1993 and later years.

${ }^{24}$ See Akbulut-Yuksel (2009) for a discussion of the microeconomic effects of wartime destruction in Germany.
} 
have migrated to the same regions in which their relatives settled before 1961, and that this migration may have increased the average wage paid in these regions. In column 7 we control for the flow of migrants from East to West post 1989, and again there is little effect on the coefficient of interest.

While none of these observable region characteristics appear to be driving our results, there might be other (unobservable) omitted variables which may be correlated with the pattern of wartime destruction and affect changes in regional growth trajectories post 1989. Alternatively, we may be misinterpreting our results in that migrants from the East may affect changes in income growth post 1989 through some channel other than social ties.

We are able to test this, and the entire class of 'sophisticated' challenges, by comparing the effects of expellees via the Soviet sector with the effects of expellees who arrived directly from the parts of pre-war Germany that were annexed by Poland and Russia. Both groups came from the same regions in Poland and the Czech Republic and look similar on observable characteristics. Moreover, there are no systematic differences in observable characteristics in 1989 between regions in which expellees of the two groups settle (see Appendix A for details). The only relevant difference between the two groups is that expellees who arrived directly from the annexed areas did not spend any significant time living (and forming social ties) in East Germany. If we misinterpret our results and the effects we document are driven by some omitted variable which determined both wartime destruction and changes in post 1989 income growth, or if there was something special about expellees per se that gave them access to business opportunities post 1989, we would expect to find that both groups of expellees have a positive effect on income growth post $1989 .{ }^{25}$

When we regress growth in income per capita post 1989 simultaneously on the share of both groups of expellees and our standard region level controls, the coefficient on expellees via the Soviet Sector is positive, statistically significant at the $1 \%$ level, and very similar to the estimates from Table $3(2.131$, s.e.=0.701). The coefficient on the share of direct expellees is negative and statistically indistinguishable from zero $(-0.092$, s.e. $=0.149)$.

As we have two measures of wartime destruction, we are also able to separately estimate the causal effects of expellees via the Soviet sector and of direct expellees on differential income growth after 1989, by instrumenting simultaneously with both the share housing destroyed and the cubic meters of rubble per capita. While the coefficient on the share of expellees via the

\footnotetext{
${ }^{25}$ In fact, the 1971 census, the last census in which expellees are separately identified, would suggest the opposite. It shows that both groups of expellees are slightly poorer, slightly less educated, and significantly less likely to be entrepreneurs than 'native' West Germans. See Appendix Table 3.
} 
Soviet sector remains positive and statistically significant at the $10 \%$ level $(3.422$, s.e. $=1.796)$, the coefficient on the share of direct expellees is again close to zero and statistically insignificant $(-0.350$, s.e. $=0.620) .{ }^{26}$ The effect on regional economic growth is thus particular to the group which had the opportunity to form social ties to East Germans before moving to the West. We view this result as strong support in favor of our interpretation.

Remaining Caveats A final concern for which we cannot control explicitly at the regional level is that expellees via the Soviet sector might be more likely than native West Germans to have restitution claims to property expropriated in East Germany. While compensation payments by law did not begin until 1996 (Southern, 1993), the restitution of assets began in the early 1990s and could potentially confound our measure of income per capita. However, we argue in Appendix B that any bias they may induce in our estimates would quantitatively small.

The same appendix presents a number of additional robustness checks and discusses proximate interpretations of our results, such as the possibility that migrants arriving from the East may have had an unobservable emotional affinity to the East.

\section{Understanding the Effect on Regional Economic Growth}

\subsection{Entrepreneurial Activity}

In order to understand the channel linking social ties to regional economic growth, we disaggregate regional income per capita into the average income of households whose primary income derives from entrepreneurial activity (entrepreneurs) and the average income of all other households (non-entrepreneurs). ${ }^{27}$ In columns 1 and 2 of Table 4 we re-run our standard specification from column 3 in Table 3 with the growth rate in the average income of entrepreneurs and non-entrepreneurs as dependent variables. Both specifications include the same covariates as our standard specification, but add the pre-trend in income growth of each group and the level average income of each group in 1989 as an additional controls. Since the errors in the specifications in columns 1 and 2 are likely to be correlated, we estimate the two equations (as well as their first stage) jointly using the three stage least squares estimator. The coefficient estimate is 4.612 $($ s.e. $=1.733)$ for entrepreneurs (column 1$)$ and 1.270 (s.e.=0.686) for non-entrepreneurs (column 2 ), implying that a one standard deviation rise in the share of expellees via the Soviet sector is

\footnotetext{
${ }^{26}$ The two coefficients are statistically significantly different in the OLS specification ( $p$-value: 0.008$)$. In the instrumental variable specification the $p$-value is 0.117. See Appendix A for econometric details.

${ }^{27}$ In the German Mikrozensus these are households whose household heads declare that their primary occupation is Selbstständiger mit oder ohne Beschäftigte.
} 
associated with a 8.8 percentage point rise in the average income of entrepreneurs, but only a 2.4 percentage point rise in the average income of non-entrepreneurs. ${ }^{28}$ Entrepreneurs who lived in a region with strong social ties to the East thus experienced a much steeper rise in their average income than non-entrepreneurs living in the same region.

This strong effect on the income of entrepreneurs is mirrored by an increase in the number of entrepreneurs. In column 3 we re-run our standard specification but use the change in the share of the population who are entrepreneurs between 1989 and 1995 as the dependent variable, where we again add pre-trend in the change of this share and the level of this share in 1989 as an additional control. The coefficient of interest is 0.334 (s.e. $=0.163$ ), implying that a one standard-deviation rise in the share of expellees induces a 0.63 percentage point rise in the share of the population engaged in entrepreneurial activities. This is a sizable effect, corresponding to a $14.7 \%$ rise relative to the mean share of entrepreneurs in 1989 (0.043).

\subsection{Firm Investment}

The significant rise in entrepreneurial activity in regions with strong social ties to the East suggests that firms which were based in these regions generated higher profits in the years following the fall of the Berlin Wall. One possible reason for such a rise in profitability is that locating in a region with strong social ties to the East may have generated a comparative advantage in investing in the East. We explore this possibility by examining the holdings of subsidiaries and branches of West German firms in East Germany.

We have data on 19,387 firms whose headquarters are located in West Germany. For these firms we construct a dummy variable which is one if the firm operates a subsidiary or branch in East Germany and zero otherwise. Since West German firms could not own assets in East Germany prior to the fall of the Berlin Wall, any subsidiaries or branches that they operate in 2007 must have been acquired after 1989. Our dummy variable is thus informative both about the investment behavior of West German firms in East Germany since 1989 and about a possible long-lasting effect of social ties in 1989 on the economic structure of West Germany.

The structural equation of interest is

$$
b_{k d r}^{07}=\delta T_{d r}^{89}+\phi^{f} Y_{r}^{89}+\mathbf{Z}_{k d r}^{\prime} \zeta^{f}+\varepsilon_{k d r}
$$

where $b_{k d r}^{07}$ stands for the dummy indicating whether firm $k$ in West German district $d$ and region

\footnotetext{
${ }^{28}$ The $p$-value on the null hypothesis that the two coefficients on Share Expellees (Soviet Sector) '61 are equal in columns 1 and 2 is 0.058 .
} 
$r$ operates a subsidiary or a branch in East Germany in 2007. $T_{d r}^{89}$ is again our proxy of social ties between the residents of district $d$ in region $r$ and East Germany in 1989; $Y_{r}^{89}$ stands for $\log$ income per capita in region $r$ in 1989; and $\mathbf{Z}_{k d r}$ is a vector of firm and district level controls which contains a complete set of state fixed effects, a fixed effect for the sector in which the firm has its primary operations, the log of the number of subsidiaries and branches that firm $k$ operates in West Germany, and the distance between district $d$ and the inner-German border. (Note that income per capita in 1989 is available only at the regional level and not at the district level.) We cluster all standard errors at the district level to account for likely spatial correlation.

The coefficient of interest is $\delta$ which measures the effect of the intensity of social ties to the East in a given West German district in 1989 on the probability that a firm headquartered within that district operates a subsidiary or branch in East Germany in 2007. ${ }^{29}$ As in Section 4, we account for the possibility that our measure of social ties (the share of expellees via the Soviet sector settling in a West German region in 1961) is jointly determined with income growth by instrumenting $T_{d r}^{89}$ with the share of housing destroyed in 1946. The first stage of our instrumental variables strategy is thus the analog to (2) at the district level. ${ }^{30}$ Panel A of Table 5 shows reduced form estimates, relating the share of housing destroyed in 1946 directly to the probability that a given firm operates a subsidiary or branch in East Germany in 2007. In column 1, we regress our dummy variable on the share of housing destroyed in the district and the log of the number of subsidiaries and branches that the firm operates in West Germany in 2007, which we use as a simple control for the size of the firm. The coefficient of interest is -0.030 (s.e. $=0.011$ ) and statistically significant at the $1 \%$ level. The estimate implies that a one standard deviation rise in the share of housing destroyed in a West german district (0.24) is associated with a 0.7 percentage point drop in the probability that a firm based in that district operates a subsidiary or branch in East Germany in 2007. Unsurprisingly, the coefficient on our size control is positive and significant, reflecting the fact that larger firms are also more likely to operate in East Germany. Columns 2-5 add all of the now familiar district- and region level covariates from Section 4, and column 2 gives the analog of our standard specification. Throughout, the coefficient of interest remains in a tight range between -0.026 and -0.030 and is statistically significant at the $5 \%$ level.

Panel B shows our instrumental variables estimates of equation (3), which use the variation in wartime destruction to quantify the causal effect of social ties in 1989 on the investment behavior of West German firms. All specifications contain the same covariates as those in Panel A. The

\footnotetext{
${ }^{29}$ We use a simple linear probability model, since this allows for a straight-forward interpretation of the coefficient. The results are essentially unchanged when we use a probit estimator.

${ }^{30}$ The first stage results at the district level are almost identical those reported in Panel A of Table 2 . For example, the coefficient of interest in the first stage corresponding to column (2) of Table 5 is -0.019 (s. e.=0.005).
} 
estimates in all columns are positive and statistically significant at the $5 \%$ level. The estimate from our standard specification in column 2 is 1.496 (s.e.=0.673), which implies that a one standard deviation rise in the share of expellees via Soviet sector in a West German district (0.019) is associated with a 2.8 percentage point increase in the probability that a firm based in that district will operate a subsidiary or a branch in East Germany in 2007. (This corresponds to $36 \%$ increase relative to the mean.)

The remaining panels of Table 5 show the results of a number of falsification exercises. If the pattern in holdings of subsidiaries and branches prevailing in 2007 is truly attributable to variation in social ties to East Germany in 1989, and not to some other factor correlated with firm investment, our measure of social ties to East Germany should predict investment in East Germany but not in other areas of the world. ${ }^{31}$ Panels C-F repeat the same specifications as in Panel B, but with a dummy variable indicating whether a firm operates subsidiaries or branches in Poland or the Czech Republic, in the 'old' EU countries (the 14 member countries other than Germany prior to the enlargement in 2004), in the 'new' EU countries (the 8 countries, other than Poland and Czech Republic, which joined the EU in 2004), and in non-EU countries as the dependent variable. All estimated coefficients in Panels D, E and F are statistically indistinguishable from zero. Firms which are based in districts with a high share of expellees via the Soviet sector are thus not more likely to operate subsidiaries or branches in areas other than East Germany. Interestingly, however, the only exception from this rule is that the estimates for Poland or Czech Republic are positive and statistically significant at the $5 \%$ level in all columns. The estimated effect is about $1 / 5$ th the size of the effect estimated for East Germany. Since the largest group of expellees who settled in West Germany after 1945 actually came from areas that are today part of Poland and the Czech Republic, these results suggest a possible additional effect of social ties to Poland and the Czech Republic on the investment behavior of West German firms. (Although the size of the coefficient for Poland/Czech Republic is similar to that of some of the other, insignificant coefficients.)

In Appendix Table 8 we explore whether social ties may have been especially relevant for the investment behavior of firms in any particular sector by interacting the share of expellees via the Soviet sector with each of the four sectoral fixed effects included in the specification. The estimated effects in the agriculture, government, and manufacturing sectors are statistically insignificant, while the effect estimated for the services sector is positive and statistically signifi-

\footnotetext{
${ }^{31}$ If firms from districts with a high fraction of expellees were merely good at capitalizing on new business opportunities, regardless of social ties, we might, for example, expect to see an effect on their holdings in other Eastern European countries following consecutive rounds of EU enlargement.
} 
cant at the $5 \%$ level $(2.121$, s.e. $=1.012)$. We may interpret this as evidence that social ties were particularly important for firm investment in the services sector, which is arguably the sector of the economy which is most susceptible to informational asymmetries and reliant on knowledge of local demand. However, most of the firms in our sample have their primary focus in this sector such that we interpret this result with due caution. (Unfortunately it is not possible to further disaggregate the services sector with the data available.)

\section{Social Ties and Household Income}

If the presence of households who have social ties to East Germany encourages local firms to invest in the East and has beneficial effects on income growth at the regional level, we would expect these households to internalize part of the income growth which they generate at the regional level. In this section we analyze the direct effect of social ties on household income growth and use a structural model to link our estimates at the household and at the region level.

Panel C of Table 1 gives summary statistics for the entire panel of 1857 households, and for the subsets of households which report and do not report ties to relatives in East Germany. The heads of households with ties to the East are less likely to be female (17\% versus $26 \%$ ) and have slightly higher income on average (DM 3460 versus DM 3236). However, the two subsets of households look similar on other observable dimensions, such as the amount of capital income, the share of household heads engaged in entrepreneurial activity, and the share unemployed.

Column 1 of Table 6 uses the household level data to estimate the analog of our standard specification at the region level by relating household income growth post 1989 to a dummy that indicates ties to the East, household income in 1989, the pre-trend in household income, distance to the East, and state fixed effects. The coefficient of interest is 0.059 (s.e. $=0.025$ ), suggesting that households with ties to East Germany experience on average 6 percentage points higher income growth in the 6 years following the fall of the Berlin Wall than comparable households who do not have such ties.

\subsection{Structural Estimation}

We relate this household level estimate to the effect of social ties on regional income growth using a 'linear in means' model of social interaction. In this model, the income growth of an individual household is a function of its own characteristics as well as a function of the average income growth of households in the region and of the share of households in the region who have social ties to the East: 


$$
\hat{y}_{i r}^{95}=\mu \hat{Y}_{r}^{95}+\beta t_{i r}^{89}+\sigma T_{r}^{89}+\mathbf{z}_{i r}^{\prime} \zeta^{h h}+\mathbf{Z}_{r}^{\prime} \zeta+\varepsilon_{i r}
$$

where $\hat{y}_{i r}=y_{i r}^{95}-y_{i r}^{89}$ denotes household income growth between 1989 and 1995 ( $y_{i r}^{t}$ again refers to $\log$ household income in year $t$ ), and $t_{i}^{89}$ is the dummy variable indicating ties to East Germany. $\mathbf{z}_{i r}$ is a vector of household level controls that contains log household income in 1989, income growth between 1985 and 1989, and the region's distance to East Germany. The upper case variables $\hat{Y}_{r}^{95}, T_{r}^{89}$, and $\mathbf{Z}_{r}$ refer to the regional averages of the corresponding household level variables. In particular, we now interpret $T_{r}^{89}$ as the share of the region's households who have social ties to the East.

While $\beta$ measures the direct effect of ties to the East on the income of households who have these ties, $\sigma$ and $\mu$ measure regional spill-over effects. The parameter $\sigma$ measures the effect of indirect social ties, i.e. the effect of the share of the region population who have ties to the East on the income of an individual household who itself may or may not have such ties. Indirect social ties affect household income in settings in which information or social collateral can be exchanged through friends of friends (higher-order social ties), or in which neighbors of households with ties to the East are more likely to form their own social ties to the East. ${ }^{32}$ The parameter $\mu$ measures the local economic multiplier, i.e. the extent to which a rise in the average income of a given region raises the income of an individual household. Such local economic multipliers operate in settings in which a rise in household spending results in an increase in the demand for local non-traded goods and services. ${ }^{33}$

While we cannot separately identify the two spill-overs $\sigma$ and $\mu$ (this is the well-known 'reflection problem', Manski (1993)), we are able to identify their composite effect as well as the direct effect of social ties, $\beta$.

Summing both sides of equation (4) across the households in each region and solving for $\hat{Y}_{r}^{95}$ yields our region level specification (1). ${ }^{34}$ In light of this model, our region level estimates of $\alpha$ can thus be understood as a composite effect the local multiplier and the direct and indirect effects of social ties,

$$
\alpha=\frac{\sigma+\beta}{1-\mu} .
$$

Plugging the region level specification (1) back into (4) yields a specification which allows a

\footnotetext{
${ }^{32}$ The biography of an entrepreneur which inspired this paper (Schulze, 2005) presents an example of such interaction at the second degree of separation. For a formal argument see for example Karlan et al. (2009).

${ }^{33}$ See for example Moretti (2010) and Mian and Sufi (2011).

${ }^{34}$ For simplicity we abstract from the correction for Jensen's inequality and assume that the difference in the variance of log income between 1989 and 1995 is zero, such that we can write $\hat{Y}_{r}=Y_{r}^{95}-Y_{r}^{89}$.
} 
joint estimation of $\alpha$ and $\beta$. It relates household level income growth post 1989 to the dummy indicating ties to the East, the share of the region population who have ties to the East, and our standard controls at the household and at the region level

$$
\hat{y}_{i r}^{95}=\beta t_{i r}^{89}+(\alpha-\beta) T_{r}^{89}+\mathbf{z}_{i r}^{\prime} \chi^{h h}+\mathbf{Z}_{r}^{\prime} \chi+\nu_{i r}
$$

Column 2 of Table 6 estimates this specification using our household level data. The coefficient estimates on both variables of interest are positive but remain statistically insignificant. It thus appears that our household level dataset lacks the statistical power to jointly identify household and region level effects, which is not surprising as we have data for on average only 25 households per region.

However, specification (6) allows us to separately estimate $\beta$ by adding region fixed effects on the right hand side and dropping all region level covariates. Column 3 presents results from this fixed effects regression, relying only on the variation within regions for identification. The coefficient of interest is now very similar to that in column $1(0.067$, s.e. $=0.024)$ and statistically significant at the $1 \%$ level. (The number of observations increases to 1857 because we now include households located in regions for which we have no data on wartime destruction.) Column 4 adds controls for age and gender of the household head. This again induces only minor changes in the coefficient of interest $(0.058$, s.e. $=0.021) .{ }^{35} 36$

Column 5 of Table 6 returns to our region level data and re-estimates the parameter $\alpha$ using the share of households who have ties to the East as proxy for $T_{r}^{89}$. The coefficient estimate is 0.338 (s.e. $=0.197$ ) and statistically significant at the $10 \%$ level. This estimate has almost identical quantitative implications as the estimates in Table 3 (a one standard deviation rise in the share of households with ties to the East (0.140) is associated with a 4.73 percentage point rise in income per capita). However, it has the added advantage that it is directly comparable to our household level estimates of $\beta$, as the share of households with ties to the East is the regional average of the dummy indicating ties to the East.

Equation (6), the estimate of $\alpha$ from column 5, and the estimate of $\beta$ from column 3 thus

\footnotetext{
${ }^{35}$ This coefficient estimate is essentially unchanged for a range of different definitions of the dummy $t_{i}$ that use information on friendships in the East and information on different intensities of contact between friends and relatives.

${ }^{36}$ Since our model contains a lagged dependent variable there may again be a mechanical bias in the coefficient of interest. We cannot perform an Arellano-Bond style estimation as we do not have enough pre 1989 data. However, if we drop the control for the pre-existing growth trend, we can instrument for household income in 1989 with household income 1985. In this case the coefficient of interest is estimated to be 0.046 (s.e. $=0.023)$ and significant at the $5 \%$ level.
} 
jointly imply that

$$
\sigma=0.338-0.405 \mu
$$

Appendix Figure 4 plots this estimated relationship between the effect of indirect social ties on household income and the local multiplier along with $90 \%$ confidence intervals, which we calculate form a bootstrapped variance-covariance matrix of $\alpha$ and $\beta .{ }^{37}$

The estimated effect of indirect social ties on household income thus depends on the size of the local multiplier, which we cannot identify separately. However, a large literature has produced a range of estimates of $\mu$. For example, Nakamura and Steinsson (2011) estimate that a $1 \%$ increase in regional government spending increases regional economic output by $1.5 \%$. Assuming that West German households regard their income gains post 1989 as quasi-permanent, we may expect a marginal propensity to consume around 0.8 such that $\mu=0.4$ might be a reasonable assumption. This would imply that $\sigma=0.136$ (s.e.=0.087). Other things equal, a direct social tie to the East thus has the same effect on individual household income as a $\frac{\beta}{\sigma}=49.3$ percentage point (or 3.5 standard deviation) increase in the regional share of households who have such ties.

Alternatively, we may interpret this estimate in the context of a network-based model in which households have a fixed number (say 10) random links to other households in their region, accrue the benefit $\beta$ if they have at least one first degree (direct) tie to the East, and accrue the benefit $\kappa \beta$ from each second degree (indirect) tie to the East. In such a model our estimates imply that $\kappa=\frac{\sigma}{10 \beta}=0.24$. Each second degree link thus has about a quarter of the economic value of a direct tie to the East.

Both interpretations suggest that, from the perspective of an individual household, the incremental benefit from a direct social tie to the East is large compared to the incremental benefit from higher-order social interaction. As a result, households with direct ties to the East experience on average a rise in their household income which is more than twice as large than that of households without such ties. ${ }^{38}$

However, plugging our estimate of $\sigma$ into (5) suggests that $\frac{\sigma /(1-\mu)}{\alpha}=66.0 \%$ of the effect of social ties on regional economic growth is attributable to indirect, rather than direct, social ties. The relatively smaller effect of indirect ties at the household level accounts for two thirds of the region level effect because it potentially affects the income of all, rather than just a subset, of a region's households.

\footnotetext{
${ }^{37}$ See caption of Appendix Figure 4 for details.

${ }^{38}$ The average of $T_{r}^{89}$ across households with ties and without ties is 0.349 and 0.301 , respectively. The average of the first two terms in (6) across households with ties relative to the average across households without ties is thus $\frac{(\alpha-\beta) 0.349+\beta}{(\alpha-\beta) 0.301}=1.98$.
} 


\subsection{Robustness}

For specification (6) to estimate the coefficient of interest consistently we require $\operatorname{Cov}\left(t_{i r}, \nu_{i r}\right)=$ 0. As ties to relatives could not have had an economic benefit prior to 1989, we believe this condition does not fail due to reverse causality. However, it may still fail if households with ties to the East are also more likely than other households to have some omitted characteristics that affect their income growth differently after 1989 than before 1989.

As a systematic approach to detecting any omitted variables we select all relevant variables from the 1989 wave of the SOEP that pertain to education; occupational status; industry of employment; professional affiliation; union membership; asset holdings; and sources of income and regress them on our dummy variable indicating Ties to the East as well as our standard control variables. Conditional on these controls, there are no systematic differences between households with and without ties in the 26 variables we consider (see Appendix Table 10). The only exceptions are that households with ties to the East are less likely to be employed in the government sector and that they pay (but do not receive) significantly higher transfers to relatives living outside their household throughout the sample period.

Appendix $\mathrm{C}$ shows that our results remain unchanged if we control for these and a range of other potentially interesting variables, such as educational attainment and whether the household head is an entrepreneur. In addition, the same appendix also shows that the results are robust to excluding all households from the sample that potentially received restitutions of assets from the East, and to using propensity score matching as an alternative estimator.

In Figure 4 we explore the timing of the effect by regressing household income in each year between 1985 and 2001 on the dummy indicating ties to the East and our standard control variables. The figure shows the coefficients on $t_{i r}^{89}$ from each of the regressions and a $90 \%$ confidence interval. ${ }^{39}$ Each coefficient measures the differential income growth of households with social ties to the East between 1989 and the indicated year, while controlling for income growth between 1985 and 1989. (This is why there is no coefficient estimate for both of these years.) The pattern is striking: the coefficients are negative and statistically indistinguishable from zero until 1989, when they change sign and remain positive until the end of the sample. The coefficients for the years 1992, 1995, and 1998 are statistically significant at the 5\% level and the coefficient for 1997 is significant at the $10 \%$ level. The timing of the effect is thus again supportive of the view that social ties to the East became relevant for income growth only after the fall of the Berlin Wall.

\footnotetext{
${ }^{39}$ The sample size decreases monotonically from 1857 in 1995 to 1369 in 2001.
} 


\subsection{Heterogeneous Effects}

In addition to establishing the robustness of our results, the wealth of information in the SOEP allows us to further explore the mechanism underlying the household level effect of social ties and to distinguish it from two closely related notions of affinity between regions.

First, we may suspect that individuals who lived in East Germany during their youth retain knowledge about local economic conditions, which enables them to earn rents after reunification even if they do not have personal contact with East Germans. However, when we add a fixed effect for households in which at least one member reports to have lived in East Germany prior to 1961 to our standard specification (column 4 of Table 6), the coefficient on this fixed effect is negative and statistically insignificant $(-0.057$, s.e. $=0.045)$, while the coefficient on Ties to Relatives '91 remains positive and statistically significant at the $1 \%$ level $(0.068$, s.e. $=0.021)$.

Consistent with this result, column 1 of Table 7 shows that even households headed by individuals who were too young to remember living in East Germany experience a rise in their income after 1989. The specification shown again departs from our standard specification, but interacts the dummy for ties to relatives with a fixed effect for the age quartile of the household head (and also adds fixed effects for each age quartile on the right hand side). The pattern suggests that all age groups, except those aged 40-51, profit similarly from their ties to the East. Importantly, the coefficient estimate for the youngest age quartile (those aged below 40 in 1989) is positive and significant at the $5 \%$ level, 0.121 (s.e.=0.057). The household heads in this group were younger than 11 years old at the time when the Berlin Wall was built and thus could not have had much local economic knowledge about East Germany. However, they could keep in contact with their relatives in East Germany. Both pieces of evidence thus support our view that households profit from knowing people and not from knowing places.

Second, some of the behavior we documented at the regional level, such as an increase in entrepreneurial activity and a higher propensity of firms to invest in the East, might be explained if West Germans with social ties to the East were more optimistic about economic growth in the newly unified Germany. However, we find no evidence of systematic differences in expectations about aggregate economic development or individual job security between households with and without ties to the East (see Panel C of Appendix Table 10).

Another interesting question is whether households who are wealthier were able to benefit more from their social ties to the East. (We would expect this to be the case if social ties act primarily as conduits for borrowing and lending in an environment in which East Germans have very little access to credit markets.) In column 2 of Table 7 we again depart from our standard 
specification and add the interaction of the ties to relatives dummy with a dummy that is one if the household's capital income in 1989 is above the 75th percentile (we again add the main effect of this dummy on the right hand side). The estimate on the ties to relatives dummy is very similar to that in our standard specification $(0.050$, s.e.=0.024). However, the interacted variable remains insignificant, suggesting that West German households benefited from their ties to East Germans regardless of their wealth in 1989. Column 3 shows similar results, using the 95th percentile of household capital income.

In column 4 we add a fixed effect for household heads who are entrepreneurs and the interaction of this fixed effect with the dummy indicating ties to the East. While again the main effect of ties to the East remains stable, the interaction is now positive and statistically significant at the $5 \%$ level $(0.168$, s.e. $=0.078)$. The size of the coefficient on the interaction term is roughly triple the size of the coefficient on the main effect of social ties, suggesting that ties to the East on average raise the income of entrepreneurs four times as much as they raise the income of non-entrepreneurs. This relative effect is thus very similar to the one we find in the region level regressions of Table 4.

\subsection{East German Households}

Throughout the paper we have focused on the economic effects of social ties on outcomes in West Germany. An obvious question is what effects the same social ties have in East Germany. Unfortunately, we have no information on where in East Germany migrants lived before migrating to the West or on the degree of wartime destruction across East Germany. Therefore we cannot replicate our region level results for East Germany. However, we can replicate part of our standard specification in column 4 of Table 6 for households in East Germany. In particular, Appendix Table 11 shows results of regressions relating log income of East German households in the years after German reunification to a dummy variable indicating relatives in West Germany in 1991 as well as our standard household level covariates. As we have no data on income before 1989, these specifications do not control for the pre-trend in income growth. Nevertheless, we find that the estimate on the coefficient of interest similar in magnitude to our estimates for the income gains of West German households. The coefficient is positive in all years between 1990 and 1995 and marginally significant in one of the six years (1992). The results are thus consistent with the view that East German households with ties to the West have higher income growth than those without ties to the West. 


\section{Conclusion}

The question how social ties between individuals relate to the capacity of societies for economic growth is of great importance in economic theory. Theorists in many fields are beginning to incorporate network-based interactions into their models. Showing that the pattern of social ties between individuals impacts aggregate economic outcomes highlights the relevance of their work beyond the microeconomic context and facilitates a deeper theoretical understanding of otherwise puzzling correlations between measures of affinity between regions and aggregate economic outcomes, such as foreign direct investment, international asset flows, and trade.

Empirical work, however, has found it difficult to resolve a double reverse causality problem: Both the decision of individuals to form social ties and the regional distribution of individuals who make these decisions are endogenous to economic activity.

In this paper we are able to solve both layers of this reverse causality problem in the context of the natural experiment surrounding German reunification. We show that West German regions which (for idiosyncratic reasons) have a high concentration of households with social ties to the East in 1989 exhibit substantially higher growth in income per capita after the fall of the Berlin Wall. Moreover, we are able to provide evidence on the microeconomic underpinnings of this effect. We show that households who have social ties to the East in 1989 experience a persistent rise in their personal incomes and that their presence increases returns to entrepreneurial activity at the regional level as well as the likelihood that local firms invest in East Germany. These findings appear robust to a wide range of plausible variations in the estimation strategy and placebo treatments. They show that social ties between individuals can indeed facilitate economic growth.

\section{References}

Ahfeldt, G. M., S. J. Redding, D. M. Sturm, and N. Wolf (2010). The economics of density: Evidence from the berlin wall. mimeo Princeton University.

Akbulut-Yuksel, M. (2009). Children of war: The long-run effects of large-scale physical destruction and warfare on children. IZA Discussion Paper No. $440 \%$.

Alesina, A. and N. Fuchs-Schündeln (2007). Good-bye lenin (or not?): The effect of communism on people's preferences. The American Economic Review 97(4), 1507 - 1528.

Ambrus, A., M. Möbius, and A. Szeidl (2010, February). Consumption risk-sharing in social networks. NBER Working Paper Series 15719.

Anderson, T. W. and C. Hsiao (1982). Formulation and estimation of dynamic models using panel data. Journal of Econometrics 18, 47-82. 
Angrist, J. D. and J.-S. Pischke (2008). Mostly Harmless Econometrics: An Empiricist's Companion. Princeton University Press, Princeton NJ.

Banerjee, A., A. G. Chandrasekhar, E. Duflo, and M. O. Jackson (2012). The diffusion of microfinance. NBER Working Paper No. 17743.

Beaman, L. A. (2012). Social networks and the dynamics of labor market outcomes: Evidence from refugees resettled in the u.s. The Review of Economic Studies 79(1), 128-161.

Bertrand, M., E. F. P. Luttmer, and S. Mullainathan (2000). Network effects and welfare cultures. The Quarterly Journal of Economics 115(3), 1019-1055.

Besley, T. and S. Coate (1995). Group lending, repayment incentives and social collateral. Journal of Development Economics 46(1), 1-18.

Bethlehem, S. (1982). DDR-Flucht, Gastarbeiter-Zuwanderung. Klett-Cotta, Stuttgart.

Brakman, S., H. Garretsen, and M. Schramm (2004). The strategic bombing of german cities during wwii and its impact on city growth. Journal of Economic Geography 4(2), 201-218.

Bursztyn, L. and D. Cantoni (2009). Clueless? the impact of television on consumption behavior. mimeo Harvard University.

Burt, R. S. (1992). Structural Holes: The Social Structure of Competition. Harvard University Press, Cambridge MA.

Calvo-Armengol, T. and M. O. Jackson (2004). The effects of social networks on employment and inequality. The American Economic Review 94 (3), 426-454.

Chaney, T. (2011, January). The network structure of international trade. NBER Working Paper 16753.

Cohen, L., A. Frazzini, and C. Malloy (2008). The small world of investing: Board connections and mutual fund returns. Journal of Political Economy 116(5), 951-979.

Conley, T. G. and C. R. Udry (2010). Learning about a new technology: Pineapple in ghana. The American Economic Review $100(1), 35-69$.

Frank, M. (2007). Expelling the Germans: British Opinion and Post-1945 Population Transfer in Context. Oxford University Press.

Franzen, K. E. (2001). Die Vertriebenen. Propylaen, Berlin.

Friedberg, R. M. (2001). The impact of mass migration on the israeli labor market. The Quarterly Journal of Economics 116 (4), 1373-1408.

Friedrich, J. (2002). Der Brand. Propylaen, Berlin.

Fuchs-Schündeln, N. and M. Schündeln (2005). Precautionary savings and self-selection: Evidence from the german reunification experiment. The Quarterly Journal of Economics 120(3), $1085-1120$. 
Granovetter, M. (1985). Economic action and social structure: The problem of embeddedness. American Journal of Sociology 91 (3), 481-510.

Granovetter, M. (2005). The impact of social structure on economic outcomes. The Journal of Economic Perspectives 19 (1), 33-50.

Greif, A. (1993). Contract enforceability and economic institutions in early trade: The maghribi traders' coalition. The American Economic Review 83(3), 525-548.

Guiso, L., P. Sapienza, and L. Zingales (2009). Cultural biases in economic exchange. The Quarterly Journal of Economics 124(3), 1095-1131.

Hochberg, Y., A. Ljungqvist, and Y. Lu (2007). Whom you know matters: Venture capital networks and investment performance. The Journal of Finance 62, 251-301.

Holbik, K. and H. Myers (1964). Postwar Trade in Divided Germany. Johns Hopkins Press, Baltimore.

Hunt, J. (2006). Staunching emigration from east germany: Age and the determinants of migration. Journal of the European Economic Associaton 4 (5), 1014-1037.

Jackson, M. O., T. Rodriguez-Barraquer, and X. Tan (2011). Social capital and social quilts: Network patterns of favor exchange. The American Economic Review, Forthcoming.

Karlan, D., M. Mobius, T. Rosenblat, and A. Szeidl (2009). Trust and social collateral. The Quarterly Journal of Economics 124(3), 1307-1361.

Kranton, R. E. and D. F. Minehart (2001). A theory of buyer-seller networks. The American Economic Review $91(3), 485-508$.

Kuhnen, C. M. (2009). Business networks, corporate governance, and contracting in the mutual fund industry. The Journal of Finance 64 (5), 2185-2220.

Kurowski, F. (1977). Der Luftkrieg ueber Deutschland. Econ Verlag, Duesseldorf.

Manski, C. F. (1993). Identification of endogenous social effects: The reflection problem. Review of Economic Studies 60, 531-542.

Mian, A. and A. Sufi (2011). What explains high unemployment? the aggregate demand channel. mimeo Chicago Booth School of Business.

Moretti, E. (2010). Local multipliers. American Economic Review, Papers and Proceedings 100 (2).

Munshi, K. (2003). Networks in the modern economy: Mexican migrants in the u. s. labor market. The Quarterly Journal of Economics 118(2), 549-599.

Nakamura, E. and J. Steinsson (2011). Fiscal stimulus in a monetary union: Evidence from u.s. regions. mimeo Columbia University.

Portes, R. and H. Rey (2005). The determinants of cross-border equity flows. Journal of International Economics 65(2), 269-296. 
Rauch, J. E. (1999, June). Networks versus markets in international trade. Journal of International Economics 48(1), 7-35.

Rauch, J. E. and V. Trindade (2002, February). Ethnic chinese networks in international trade. The Review of Economics and Statistics 84(1), 116-130.

Redding, S. J. and D. M. Sturm (2008, December). The cost of remoteness: Evidence from german division and reunification. The American Economic Review 98(5), 1766-1797.

Sacerdote, B. (2001). Peer effects with random asignment: Results for dartmouth roommates. The Quarterly Journal of Economics 116 (2), 681-704.

Saxenian, A. (1999). Silicon Valley's New Immigrant Entrepreneurs. Public Policy Institute of California.

Schulze, I. (2005). Neue Leben. Berlin Verlag, Berlin.

Sensch, Jürgen, . (2010). Bautätigkeit und wohnungen, deutschland 1871 bis 1980 . GESIS Datenkompilation.

Shue, K. (2011). Executive networks and firm policies: Evidence from the random assignment of mba peers. mimeo University of Chicago.

Southern, D. B. (1993). Restitution or compensation: The land question in east germany. The International and Comparative Law Quarterly 42(3), 690-697.

Stiglitz, J. E. (1990). Peer monitoring and credit markets. The World Bank Economic Review $4(3), 351-366$.

USGPO (1945). The United States Strategic Bombing Survey: the Effects of StrategicBombing on the German War Economy. Washington DC: U.S. Government Print Office.

Varian, H. R. (1990). Monitoring agents with other agents. Journal of Institutional and Theoretical Economics (Zeitschrift fur die gesamte Staatswissenschaft) 146, 153-174. 


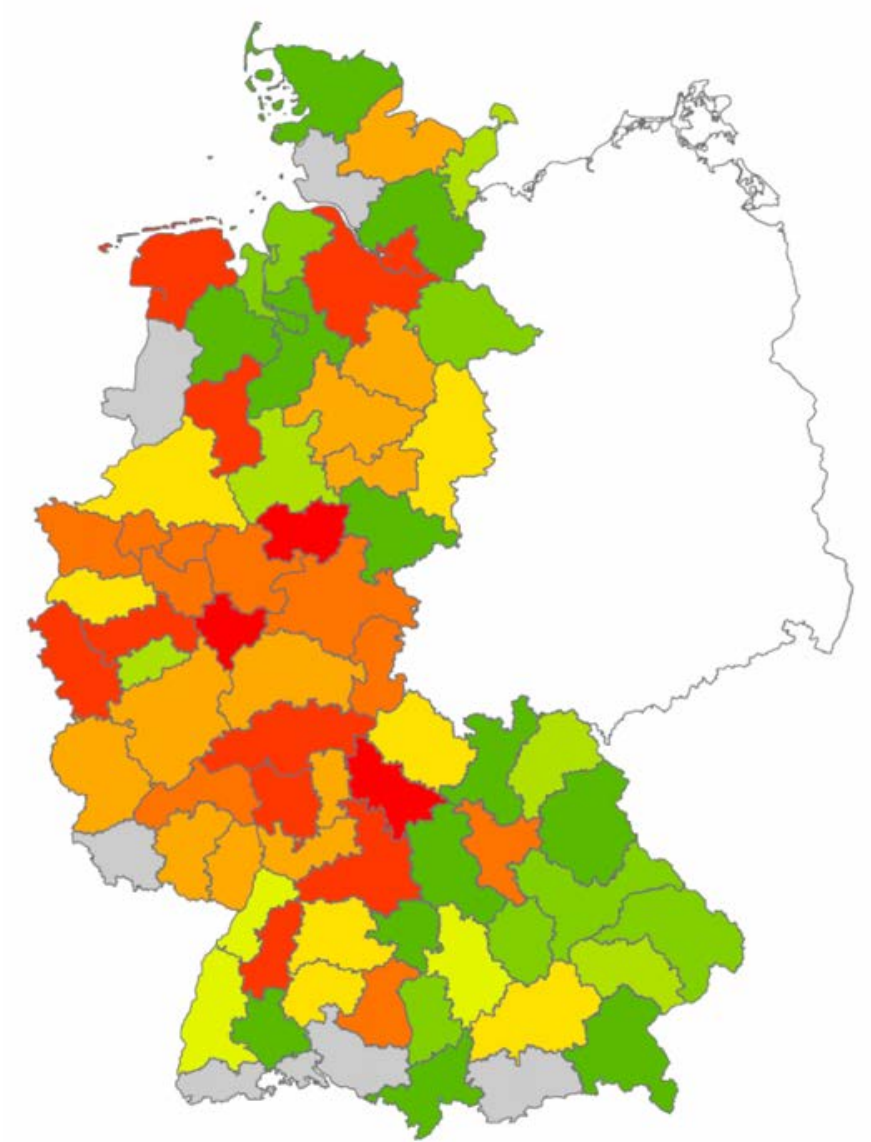

Notes: The figure presents the level of Share Housing Destroyed ' 46 in West German regions. The 5 colors refer to the 5 quintiles of war destruction, with red indicating those regions worst destroyed and green indicating the least destroyed regions. The cut-off values for the quintiles of share housing destroyed are $0.093,0.267,0.377$ and 0.526 , respectively. The median level of housing destroyed in each quintile is $0.034,0.189,0.335,0.406$ and 0.591 , respectively. Grey areas indicate regions for which we do not have data.

Figure 2: Share Expellees and Share Housing Destroyed (Conditional Scatterplot)

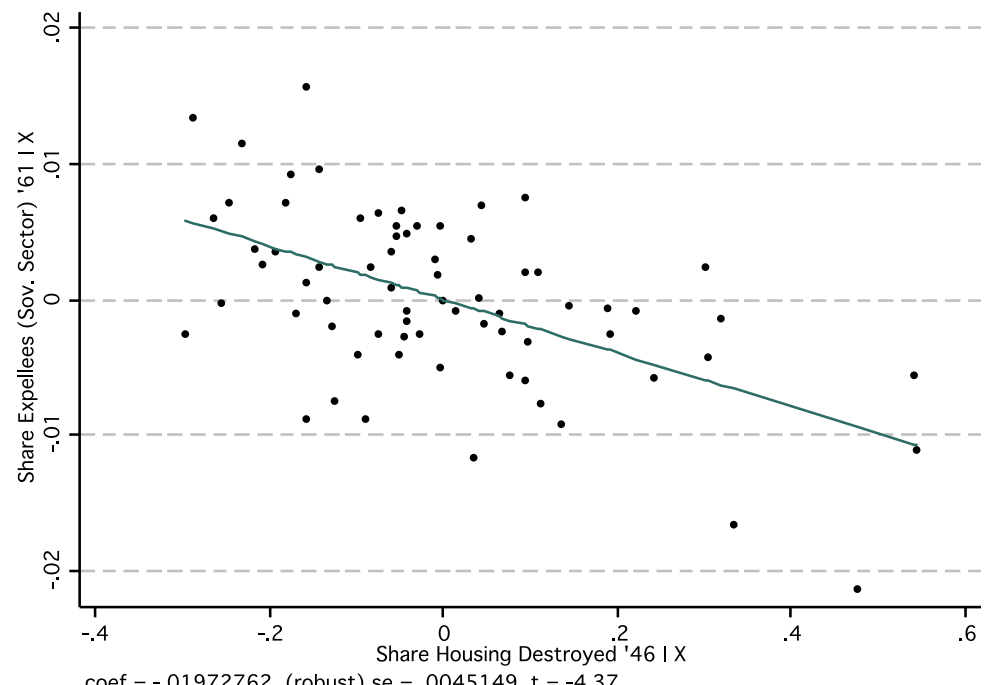

Notes: The figure is a conditional scatterplot of Share Housing Destroyed ' 46 and Share Expellees (Soviet Sector) '61 at the regional level. The corresponding first stage regression (shown in column 2 of Panel A of Table 2) controls for distance to the inner-German border, the log of per capita income in 1989, the log of the ratio of per capita income in 1989 and 1985 and a full set of state fixed effects. The solid line depicts the fitted regression line. The coefficient estimate is -0.020 (s.e.=0.004) and significant at the $1 \%$ level. 
Figure 3: Effect of Wartime Destruction on Population Growth

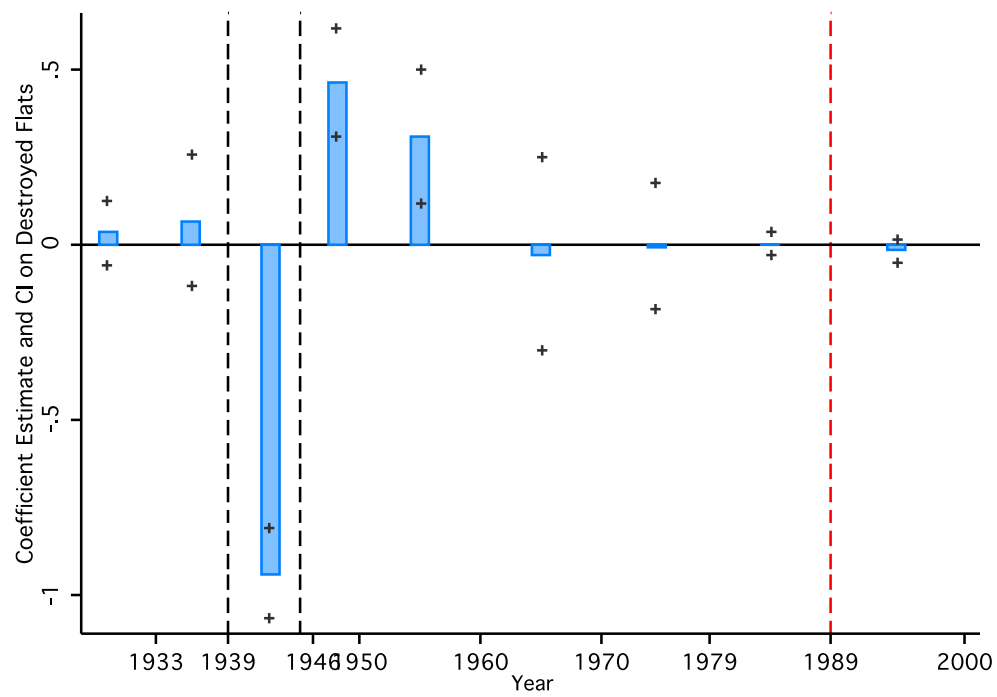

Notes: The figure depicts coefficient estimates from city-level regressions of population growth on share housing destroyed during World War II. We ran separate regressions for each time interval shown on the horizontal axis of the figure. In each of these regressions the dependent variable is city population growth in the time interval shown. The explanatory variable is always city-level Share Housing Destroyed ' 46 and a constant. The bars in the figure present the respective coefficient estimates on Share Housing Destroyed ' 46 , the crosses give $90 \%$ confidence intervals. Standard errors are calculated using the Huber-White correction to account for potential heteroscedasticity. The city-level population panel is unbalanced. It contains information for between 144 and 165 cities on population growth between 1925-1933, 1933-1939, 1970-1979, 1979-1989, and 1989-2000; it contains information for 73 cities on population growth between 1939-1946, and 1946-1950; but it only contains information for 17 cities on population growth between 1950-1960, and 1960-1970. Missing data tends to be from smaller cities. The black dashed lines indicate the time of World War II, the red dashed line indicates the time of the fall of the Berlin Wall.

Figure 4: Effect on Household Income over Time

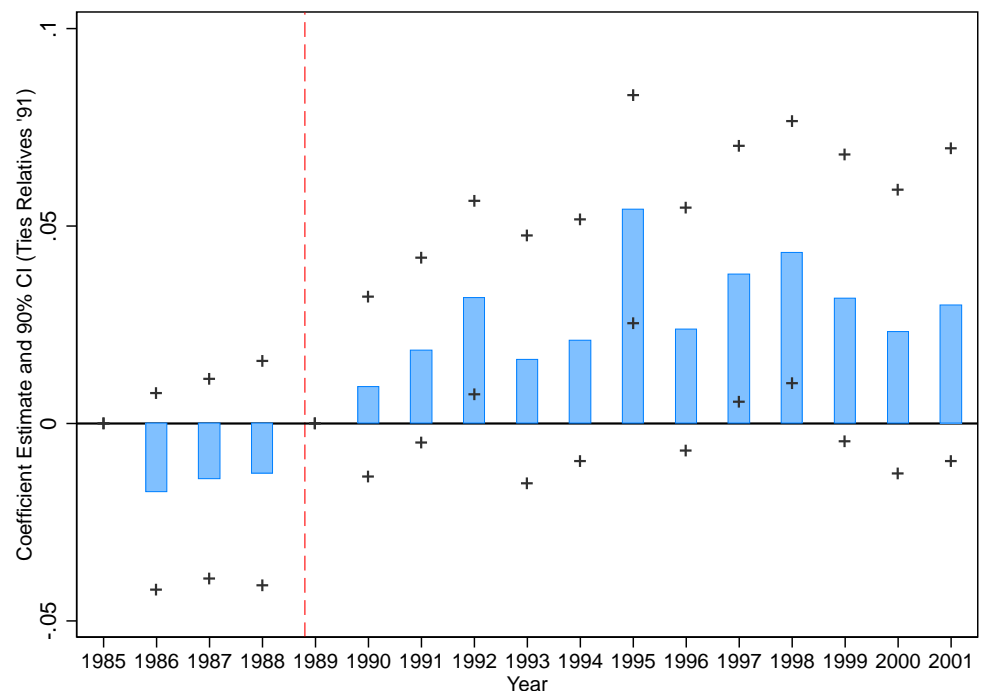

Notes: The figure depicts coefficient estimates (and 90\% confidence intervals) on Ties Relatives '91. Each coefficient estimate is obtained from a regression corresponding to our standard specification in column 4 of Table 6 , with the exception that the outcome variable is the logarithm of household income in the year specified on the horizontal axis. The estimate for 1995 replicates the core result from our standard specification. 
TABle 1: Summary Statistics

\begin{tabular}{|c|c|c|c|}
\hline & $(1)$ & $(2)$ & $(3)$ \\
\hline PANEL A: Region Level Data & All & Low Destr. & High Destr. \\
\hline Share Expellees (Soviet Sector) '61 & $\begin{array}{c}0.048 \\
(0.019)\end{array}$ & $\begin{array}{c}0.050 \\
(0.022)\end{array}$ & $\begin{array}{c}0.047 \\
(0.016)\end{array}$ \\
\hline Share Expellees (Direct) '61 & $\begin{array}{c}0.120 \\
(0.045)\end{array}$ & $\begin{array}{c}0.144 \\
(0.041)\end{array}$ & $\begin{array}{c}0.096 \\
(0.036)\end{array}$ \\
\hline Share Ties to Relatives '91 & $\begin{array}{c}0.297 \\
(0.140)\end{array}$ & $\begin{array}{c}0.321 \\
(0.156)\end{array}$ & $\begin{array}{c}0.274 \\
(0.122)\end{array}$ \\
\hline Share Housing Destroyed ' 46 & $\begin{array}{c}0.318 \\
(0.210)\end{array}$ & $\begin{array}{c}0.149 \\
(0.105)\end{array}$ & $\begin{array}{c}0.487 \\
(0.143)\end{array}$ \\
\hline Rubble '46 ( $\mathrm{m}^{3}$ p.c.) & $\begin{array}{c}0.088 \\
(0.069)\end{array}$ & $\begin{array}{c}0.034 \\
(0.028)\end{array}$ & $\begin{array}{c}0.143 \\
(0.055)\end{array}$ \\
\hline Distance to East $(100 \mathrm{~km})$ & $\begin{array}{c}1.769 \\
(1.074)\end{array}$ & $\begin{array}{c}1.543 \\
(1.060)\end{array}$ & $\begin{array}{c}1.994 \\
(1.070)\end{array}$ \\
\hline Income 1985 (DM, p.c.) & $\begin{array}{l}1595 \\
(125)\end{array}$ & $\begin{array}{l}1570 \\
(140)\end{array}$ & $\begin{array}{l}1620 \\
(106)\end{array}$ \\
\hline Income 1989 (DM, p.c.) & $\begin{array}{l}1760 \\
(132)\end{array}$ & $\begin{array}{l}1752 \\
(147)\end{array}$ & $\begin{array}{l}1768 \\
(118)\end{array}$ \\
\hline Income 1995 (DM, p.c.) & $\begin{array}{l}2222 \\
(154)\end{array}$ & $\begin{array}{l}2231 \\
(166)\end{array}$ & $\begin{array}{l}2210 \\
(143)\end{array}$ \\
\hline $\mathrm{N}$ & 70 & 35 & 35 \\
\hline PANEL B: Firm-Level Data & All & Low Destr. & High Destr. \\
\hline S. \& B. in West Germany (log) & $\begin{array}{c}0.444 \\
(0.743)\end{array}$ & $\begin{array}{c}0.437 \\
(0.729)\end{array}$ & $\begin{array}{c}0.450 \\
(0.756)\end{array}$ \\
\hline S. \& B. in East Germany (Dummy) & 0.078 & 0.083 & 0.073 \\
\hline S. \& B. in Non-EU Countries (Dummy) & 0.010 & 0.011 & 0.008 \\
\hline $\mathrm{N}$ & 19387 & 9706 & 9681 \\
\hline PANEL C: Household Level Data & All & Ties & No Ties \\
\hline Age '90 & $\begin{array}{c}51.0 \\
(14.3)\end{array}$ & $\begin{array}{c}50.5 \\
(13.4)\end{array}$ & $\begin{array}{c}51.2 \\
(14.7)\end{array}$ \\
\hline Gender & 0.23 & 0.17 & 0.26 \\
\hline Years of Education '89 & $\begin{array}{c}12.3 \\
(1.85)\end{array}$ & $\begin{array}{c}12.5 \\
(1.89)\end{array}$ & $\begin{array}{c}12.2 \\
(1.83)\end{array}$ \\
\hline Income 1989 (SOEP) & $\begin{array}{c}3307 \\
(1822)\end{array}$ & $\begin{array}{c}3460 \\
(1600)\end{array}$ & $\begin{array}{c}3236 \\
(1911)\end{array}$ \\
\hline Capital Income '89 & $\begin{array}{c}879 \\
(1811)\end{array}$ & $\begin{array}{c}822 \\
(1438)\end{array}$ & $\begin{array}{c}907 \\
(1966)\end{array}$ \\
\hline Entrepreneur '89 & 0.048 & 0.053 & 0.046 \\
\hline Not Employed '89 & 0.052 & 0.046 & 0.055 \\
\hline $\mathrm{N}$ & 1857 & 583 & 1274 \\
\hline
\end{tabular}

Notes: The table presents means (and standard deviations). Variables in Panel A refer to our sample of regions used in Tables 2 through 4. Variables in Panel B refer to our sample of firms used in Tables 5 and 8 . Panel C refers to our sample of households from the SOEP panel used in Tables 6 through 7 . Column 1 shows data for all observations. In Panel A, columns 2 and 3 show data for regions in which Share Housing Destroyed ' 46 is above and below the median, respectively. In Panel B, columns 2 and 3 present means and standard deviations for firms headquartered in regions with Share Housing Destroyed ' 46 above and below the median, respectively. S. E B. stands for subsidiaries and branches which firms headquartered in a given West German region operate in the indicated location. In Panel C, columns 2 and 3 show data for households with ties to relatives in East Germany and without ties to relatives in East Germany, respectively. Monetary values are given in nominal Deutsche Mark. The variables Age, Gender, Years of Education, Entrepreneur, and not Employed refer to the household head. Gender is a dummy variable which is one if the household head is female. See data appendix for details. 
Table 2: Wartime Destruction, Social Ties, and Income Growth

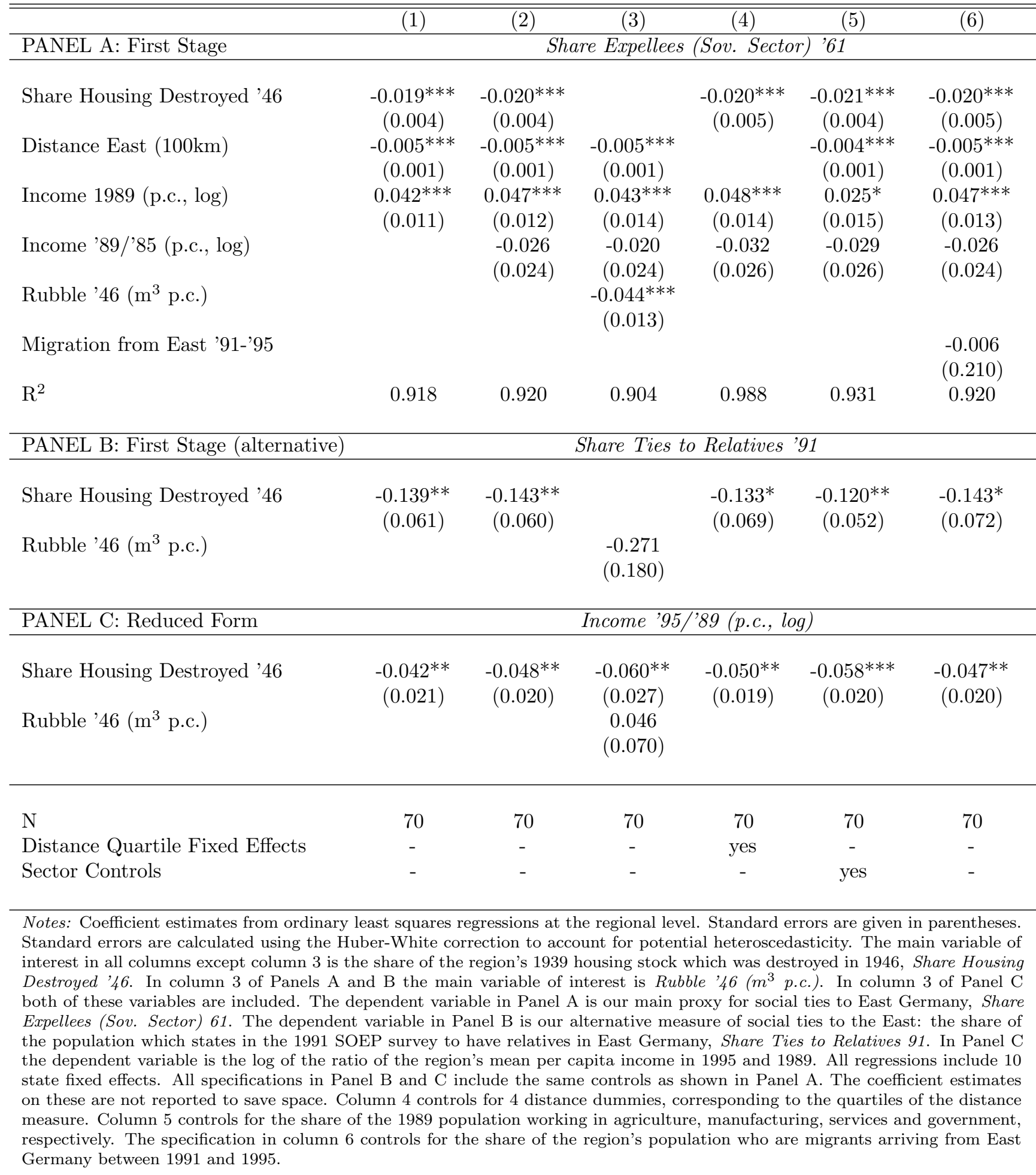


Table 3: Social Ties and Income Growth

\begin{tabular}{|c|c|c|c|c|c|c|c|}
\hline & $(1)$ & $(2)$ & $(3)$ & $(4)$ & $(5)$ & $(6)$ & $(7)$ \\
\hline & (IV) & (OLS) & \multicolumn{5}{|c|}{$(\mathrm{IV})$} \\
\hline PANEL A: Main Results & \multicolumn{7}{|c|}{ Income '95/'89 (p.c., log) } \\
\hline Share Expellees (Sov. S.) '61 & $\begin{array}{c}2.169^{* *} \\
(0.940)\end{array}$ & $\begin{array}{c}1.963^{* * *} \\
(0.570)\end{array}$ & $\begin{array}{c}2.442^{* * *} \\
(0.874)\end{array}$ & $\begin{array}{c}2.453^{* * *} \\
(0.871)\end{array}$ & $\begin{array}{c}2.473^{* * *} \\
(0.880)\end{array}$ & $\begin{array}{c}2.772^{* * *} \\
(0.848)\end{array}$ & $\begin{array}{c}2.366^{* * *} \\
(0.872)\end{array}$ \\
\hline Distance East (100km) & $\begin{array}{c}0.011^{* *} \\
(0.004)\end{array}$ & $\begin{array}{c}0.008^{* *} \\
(0.003)\end{array}$ & $\begin{array}{c}0.011^{* *} \\
(0.004)\end{array}$ & $\begin{array}{c}0.011^{* *} \\
(0.004)\end{array}$ & & $\begin{array}{c}0.012^{* * *} \\
(0.004)\end{array}$ & $\begin{array}{c}0.011^{* *} \\
(0.004)\end{array}$ \\
\hline Income 1989 (p.c., log) & $\begin{array}{c}-0.267^{* * *} \\
(0.068)\end{array}$ & $\begin{array}{c}-0.189^{* * *} \\
(0.059)\end{array}$ & $\begin{array}{c}-0.209^{* * *} \\
(0.059)\end{array}$ & $\begin{array}{c}-0.209^{* * *} \\
(0.059)\end{array}$ & $\begin{array}{c}-0.214^{* * *} \\
(0.063)\end{array}$ & $\begin{array}{c}-0.305^{* * *} \\
(0.071)\end{array}$ & $\begin{array}{c}-0.206^{* * *} \\
(0.062)\end{array}$ \\
\hline Income '89/'85 (p.c., log) & & $\begin{array}{c}-0.362^{* * *} \\
(0.082)\end{array}$ & $\begin{array}{c}-0.355^{* * *} \\
(0.085)\end{array}$ & $\begin{array}{c}-0.355^{* * *} \\
(0.085)\end{array}$ & $\begin{array}{c}-0.381^{* * *} \\
(0.089)\end{array}$ & $\begin{array}{c}-0.278^{* * *} \\
(0.083)\end{array}$ & $\begin{array}{c}-0.353^{* * *} \\
(0.086)\end{array}$ \\
\hline Sh. Employed in Agricult. '89 & & & & & & $\begin{array}{l}-0.115 \\
(0.293)\end{array}$ & \\
\hline Sh. Employed in Manufact. '89 & & & & & & $\begin{array}{c}-0.301 \\
(0.281)\end{array}$ & \\
\hline Sh. Employed in Services '89 & & & & & & $\begin{array}{c}0.145 \\
(0.288)\end{array}$ & \\
\hline Sh. Employed in Governm.' 89 & & & & & & $\begin{array}{l}-0.522 \\
(0.394)\end{array}$ & \\
\hline Migration from East '91-'95 & & & & & & & $\begin{array}{c}0.349 \\
(1.122)\end{array}$ \\
\hline $\mathrm{R}^{2}$ & 0.504 & 0.597 & 0.589 & 0.589 & 0.573 & 0.641 & 0.592 \\
\hline PANEL B: Placebo & \multicolumn{7}{|c|}{ Income '89/'85 (p.c., log) } \\
\hline Share Expellees (Sov. S.) '61 & - & $\begin{array}{c}0.656 \\
(0.598)\end{array}$ & $\begin{array}{c}0.560 \\
(1.016)\end{array}$ & $\begin{array}{c}0.557 \\
(1.022)\end{array}$ & $\begin{array}{c}0.656 \\
(0.926)\end{array}$ & $\begin{array}{c}0.443 \\
(1.093)\end{array}$ & $\begin{array}{c}0.790 \\
(1.034)\end{array}$ \\
\hline 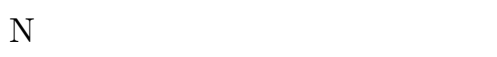 & 70 & 70 & 70 & 70 & 70 & 70 & 70 \\
\hline Distance Quartile Fixed Effects & - & - & - & - & yes & - & - \\
\hline Instruments & Housing & - & Housing & $\begin{array}{l}\text { Housing } \\
\& \text { Rubble }\end{array}$ & Housing & Housing & Housing \\
\hline
\end{tabular}

Notes: The table reports coefficient estimates from instrumental variable regressions at the regional level in columns 1 and 3 through 7 . Column 2 reports results from an ordinary least squares regression. Standard errors are given in parentheses. The standard errors are calculated using the Huber-White correction to correct for potential heteroscedasticity. In Panel A the dependent variable is the log of the ratio of mean per capita income in 1995 and 1989. In Panel B it is the log of the ratio of mean per capita income in 1989 and 1985. The main variable of interest in all columns is Share Expellees (Soviet Sector) '61. In columns 1, 3, 5, 6 and 7 we instrument for this variable with Share Housing Destroyed 46. In column 4 we use Rubble 46 ( $m^{3}$ p.c.) as an additional instrument. First stage results are shown in Table 2. All regressions include 10 state fixed effects. In Panel A all regressions control for the log of mean per capita income in 1989 and columns 2-7 include the log of the ratio of mean per capita income in 1989 and 1985 as control. In Panel B all regressions control for the log of per capita income in 1985. All regressions except column 5 control for a region's distance to the inner-German border. The specifications shown in column 5 control for 4 distance dummies, corresponding to the quartiles of the distance measure. The regressions shown in column 6 control for the share of the 1989 population working in agriculture, manufacturing, services and government, respectively. The specifications shown in column 7 controls for the share of the region's population who are migrants arriving from East Germany between 1991 and 1995. In Panel B we do not report results for covariates to save space. 
Table 4: Social Ties and Entrepreneurial Activity

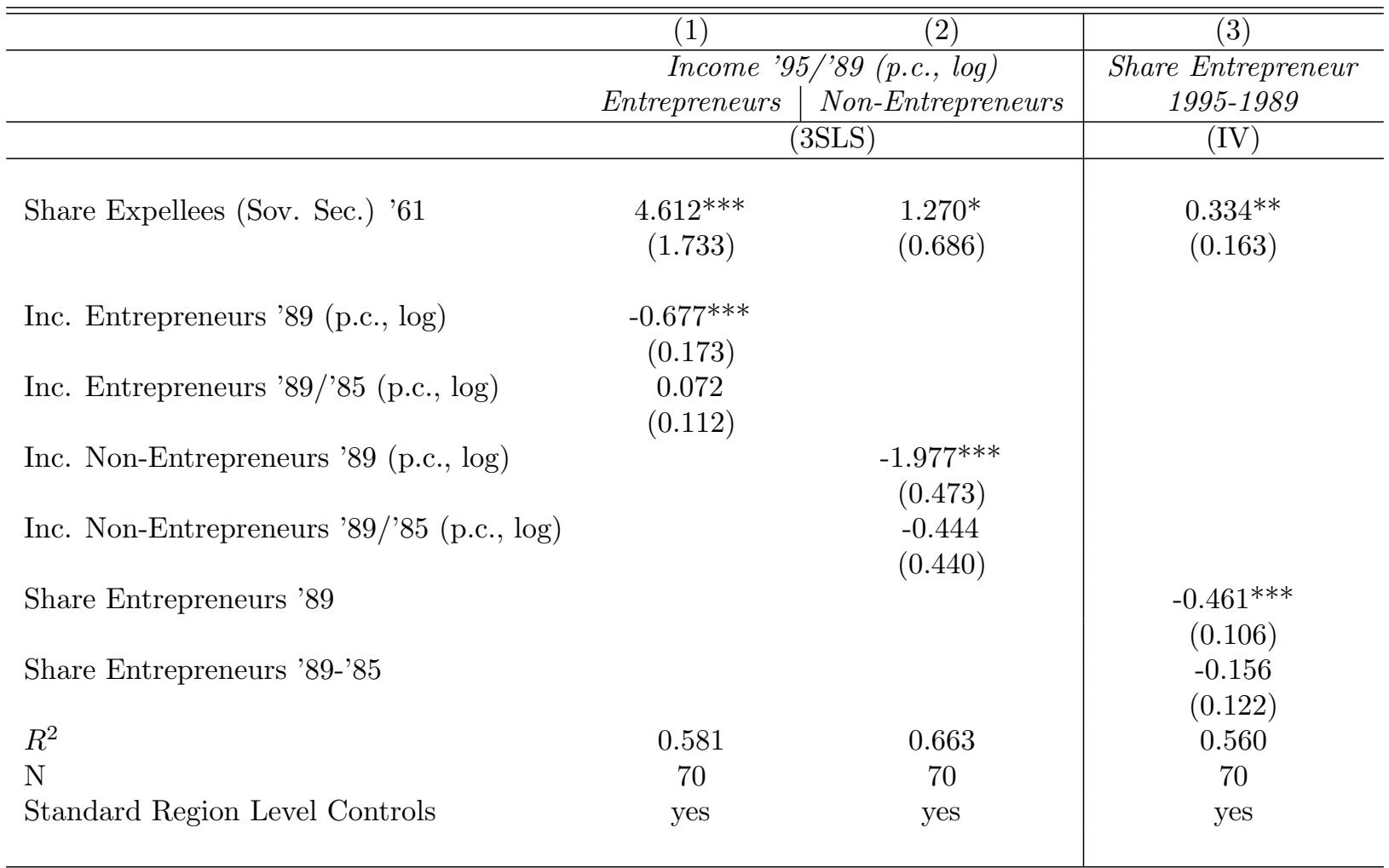

Notes: The table reports coefficient estimates from regressions at the regional level. Standard errors are given in parentheses. The dependent variable in column 1 is the log of the ratio of mean per capita income of entrepreneurs in 1995 and 1989. The dependent variable in column 2 is the log of the ratio of mean per capita income of non-entrepreneurs in 1995 and 1989. Column 1 and 2 are estimated jointly with three stage least squares, instrumenting for Share Expellees (Soviet Sector) '61 with Share Housing Destroyed '46. First stage results are not reported. In column 3, which shows results from an instrumental variables regression, the dependent variable is the share of individuals who report in 1995 to be entrepreneur. Again we instrument for Share Expellees (Soviet Sector) '61 with Share Housing Destroyed '46. The standard errors in column 3 are calculated using the Huber-White correction to correct for potential heteroscedasticity. The main variable of interest in all columns is Share Expellees (Soviet Sector) '61. All regressions control for a region's distance to the innerGerman border, the log of mean per capita income in 1989 and the log of the ratio of mean per capita income in 1989 and 1985. All regressions include 10 state fixed effects. Coefficient estimates on these controls are not reported to save space. For details on the construction of the variables see data appendix. We reject the equality of the coefficients on Share Expellees (Soviet Sector) '61 in column 1 and 2 ( $p$-value= 0.070). 
Table 5: Social Ties and Firm Investment

\begin{tabular}{|c|c|c|c|c|c|}
\hline & (1) & $(2)$ & $(3)$ & (4) & $(5)$ \\
\hline PANEL A: Reduced Form & \multicolumn{5}{|c|}{ S. E B. in East Germany (Dummy) } \\
\hline Share Housing Destroyed '46 & $\begin{array}{c}-0.030^{* * *} \\
(0.011)\end{array}$ & $\begin{array}{c}-0.029^{* *} \\
(0.011)\end{array}$ & $\begin{array}{r}-0.026^{* *} \\
(0.011)\end{array}$ & $\begin{array}{c}-0.026^{* *} \\
(0.011)\end{array}$ & $\begin{array}{c}-0.030^{* * *} \\
(0.011)\end{array}$ \\
\hline S. \& B. in West Germany (log) & $\begin{array}{c}0.119^{* * *} \\
(0.007)\end{array}$ & $\begin{array}{c}0.119^{* * *} \\
(0.007)\end{array}$ & $\begin{array}{c}0.119^{* * *} \\
(0.007)\end{array}$ & $\begin{array}{c}0.119^{* * *} \\
(0.007)\end{array}$ & $\begin{array}{c}0.119^{* * *} \\
(0.007)\end{array}$ \\
\hline Distance to East $(100 \mathrm{~km})$ & & $\begin{array}{c}-0.013^{* * *} \\
(0.004)\end{array}$ & & $\begin{array}{c}-0.014^{* * *} \\
(0.004)\end{array}$ & $\begin{array}{c}-0.015^{* * *} \\
(0.004)\end{array}$ \\
\hline Income 1989 (p.c., log) & & $\begin{array}{c}0.002 \\
(0.030)\end{array}$ & $\begin{array}{l}-0.035 \\
(0.037)\end{array}$ & $\begin{array}{c}0.060 \\
(0.064)\end{array}$ & $\begin{array}{l}-0.003 \\
(0.030)\end{array}$ \\
\hline Income '89/'85 (p.c., log) & & $\begin{array}{l}-0.010 \\
(0.050)\end{array}$ & $\begin{array}{c}0.038 \\
(0.051)\end{array}$ & $\begin{array}{l}-0.052 \\
(0.056)\end{array}$ & $\begin{array}{l}-0.019 \\
(0.051)\end{array}$ \\
\hline Migration from East'91-'95 & & & & & $\begin{array}{l}-1.559 \\
(1.223)\end{array}$ \\
\hline \multicolumn{6}{|l|}{ PANEL B: Second Stage } \\
\hline Share Expellees (Sov. Sector) '61 & $\begin{array}{c}1.579^{* *} \\
(0.689)\end{array}$ & $\begin{array}{c}1.496^{* *} \\
(0.673)\end{array}$ & $\begin{array}{c}1.252^{* *} \\
(0.583)\end{array}$ & $\begin{array}{c}1.316^{* *} \\
(0.639)\end{array}$ & $\begin{array}{c}1.548^{* *} \\
(0.671)\end{array}$ \\
\hline PANEL C: Second Stage & \multicolumn{5}{|c|}{ S. ES B. in Poland or Cz. Rep. (Dummy) } \\
\hline Share Expellees (Sov. Sector) '61 & $\begin{array}{c}0.278^{*} \\
(0.146)\end{array}$ & $\begin{array}{c}0.295^{* *} \\
(0.144)\end{array}$ & $\begin{array}{c}0.310^{* *} \\
(0.141)\end{array}$ & $\begin{array}{c}0.314^{* *} \\
(0.148)\end{array}$ & $\begin{array}{c}0.306^{* *} \\
(0.140)\end{array}$ \\
\hline PANEL D: Placebo & \multicolumn{5}{|c|}{ S. \& B. in Old EU Countries (Dummy) } \\
\hline Share Expellees (Sov. Sector) '61 & $\begin{array}{c}0.060 \\
(0.580)\end{array}$ & $\begin{array}{c}0.403 \\
(0.506)\end{array}$ & $\begin{array}{c}0.417 \\
(0.471)\end{array}$ & $\begin{array}{c}0.549 \\
(0.462)\end{array}$ & $\begin{array}{c}0.400 \\
(0.498)\end{array}$ \\
\hline PANEL E: Placebo & \multicolumn{5}{|c|}{ S. E B. in New EU, exc. Poland or Cz. Rep. (Dummy) } \\
\hline Share Expellees (Sov. Sector) '61 & $\begin{array}{c}0.220 \\
(0.197)\end{array}$ & $\begin{array}{c}0.213 \\
(0.205)\end{array}$ & $\begin{array}{c}0.201 \\
(0.192)\end{array}$ & $\begin{array}{c}0.198 \\
(0.222)\end{array}$ & $\begin{array}{c}0.248 \\
(0.199)\end{array}$ \\
\hline PANEL F: Placebo & \multicolumn{5}{|c|}{ S. E B. in Non-EU Countries (Dummy) } \\
\hline Share Expellees (Sov. Sector) '61 & $\begin{array}{c}0.034 \\
(0.304)\end{array}$ & $\begin{array}{c}0.123 \\
(0.291)\end{array}$ & $\begin{array}{c}0.116 \\
(0.274)\end{array}$ & $\begin{array}{c}0.128 \\
(0.308)\end{array}$ & $\begin{array}{c}0.138 \\
(0.284)\end{array}$ \\
\hline $\mathrm{N}$ & 19387 & 19387 & 19387 & 19387 & 19387 \\
\hline Firm-Level Sector Fixed Effects & yes & yes & yes & yes & yes \\
\hline Distance Quartile Fixed Effects & - & - & yes & - & - \\
\hline Region Level Sector Controls & - & - & - & yes & - \\
\hline
\end{tabular}

Notes: All Panels report firm-level regression results, using our sample of firms which are headquartered in West Germany. Standard errors are clustered at the district level to account for likely spatial correlation. The sample contains 136 districts. Panel A reports results from firm-level ordinary least squares regressions. Panel B-F report results of firm-level instrumental variables regressions. The main variable of interest in these specifications is Share Expellees (Soviet Sector) '61. We instrument for this variable with Share Housing Destroyed '46. Corresponding first stage results at the regional level are shown in Table 2. The dependent variable in Panels A and B is a dummy indicating whether a firm has a subsidiary or branch in East Germany. The dependent variables in panels C-F are dummies which indicate whether a firm has a subsidiary or branch in the specified location. All regressions include 10 state fixed effects and 4 firm-level sector fixed effects (agriculture, manufacturing, services, government). We control for distance to the inner-German border at the district level. Log of per capita income in 1989 and log of the ratio of per capita income in 1989 and 1985 are regional level controls. Column 3 controls for 4 distance dummies, corresponding to quartiles of the distance measure. Column 4 controls for the share of a region's 1989 population working in agriculture, manufacturing, services and government, respectively. The specification in column 5 controls for the share of the region's population who are migrants arriving from East Germany between 1991 and 1995. All specifications in Panels B-E include the same controls as the specification in Panel A, which we do not report to save space. 
Table 6: Region- And Household-Level Income

\begin{tabular}{|c|c|c|c|c|c|}
\hline & $\overline{(1)}$ & $\overline{(2)}$ & 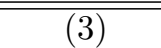 & $\overline{(4)}$ & $\overline{(5)}$ \\
\hline & \multicolumn{5}{|c|}{ Income '95/'89 (log) } \\
\hline Level (Source) & \multicolumn{4}{|c|}{ Household (SOEP) } & Aggregate (MZ) \\
\hline Ties to Relatives '91 & $\begin{array}{c}0.059 * * \\
(0.025)\end{array}$ & $\begin{array}{c}0.038 \\
(0.060)\end{array}$ & $\begin{array}{c}0.067^{* * *} \\
(0.024)\end{array}$ & $\begin{array}{c}0.058^{* * *} \\
(0.021)\end{array}$ & \\
\hline Share Ties to Relatives '91 & & $\begin{array}{c}1.078 \\
(2.576)\end{array}$ & & & $\begin{array}{l}0.338^{*} \\
(0.197)\end{array}$ \\
\hline Income 1989 (log, SOEP) & $\begin{array}{c}-0.226^{* * *} \\
(0.028)\end{array}$ & $\begin{array}{c}-0.234^{* * *} \\
(0.030)\end{array}$ & $\begin{array}{c}-0.225^{* * *} \\
(0.028)\end{array}$ & $\begin{array}{c}-0.293^{* * *} \\
(0.035)\end{array}$ & \\
\hline Income '89/'85 (log, SOEP) & $\begin{array}{c}-0.138^{* * *} \\
(0.035)\end{array}$ & $\begin{array}{c}-0.133^{* * *} \\
(0.034)\end{array}$ & $\begin{array}{c}-0.145^{* * *} \\
(0.035)\end{array}$ & $\begin{array}{c}-0.186^{* * *} \\
(0.032)\end{array}$ & \\
\hline Distance to East & $\begin{array}{c}0.006 \\
(0.014)\end{array}$ & $\begin{array}{c}0.054 \\
(0.135)\end{array}$ & & & $\begin{array}{c}0.019 \\
(0.012)\end{array}$ \\
\hline Income 1989 (p.c., log, MZ) & & $\begin{array}{l}-0.103 \\
(0.912)\end{array}$ & & & $\begin{array}{c}-0.198^{* *} \\
(0.098)\end{array}$ \\
\hline Income '89/'85 (p.c., log, MZ) & & $\begin{array}{l}-0.480 \\
(0.723)\end{array}$ & & & $\begin{array}{c}-0.334^{* *} \\
(0.153)\end{array}$ \\
\hline Age '90 & & & & $\begin{array}{c}-0.018^{* * *} \\
(0.005)\end{array}$ & \\
\hline$\left(\text { Age }{ }^{\prime} 90\right)^{2}$ & & & & $\begin{array}{c}0.000^{* *} \\
(0.000)\end{array}$ & \\
\hline Gender & & & & $\begin{array}{c}-0.076^{* * *} \\
(0.024)\end{array}$ & \\
\hline $\mathrm{N}$ & 1729 & 1729 & 1857 & 1857 & 70 \\
\hline Fixed Effects & State & State & Region & Region & State \\
\hline
\end{tabular}

Notes: Columns 1-4 show results from household level regressions. Column 5 shows results of a region level instrumental variables regression. In column 2 and 5 we instrument for the regional Share Ties to Relatives ' 91 with Share Housing Destroyed '46. First stage results for column 5 are shown in Table 2. Columns 1, 3 and 4 report results from ordinary least squares regressions. The dependent variable in columns 1-4 is the log of the ratio of household income in 1995 and 1989. The dependent variable in column 5 is the log of the ratio of per capita income in 1995 and 1989 at the regional level. Columns 2 and 5 control for the same region level variables as column 3 in Table 3. Columns 1 through 4 control at the household level for the log of household income in 1989 and the log of the ratio of household income in 1989 and 1985. Column 4 also control for the gender, age and age squared of the household head. The specifications in columns 1,2 and 5 include 10 state fixed effects. Standard errors are given in parentheses. Standard errors are clustered at the regional level, which for column 5 coincides with heteroscedasticity robust standard errors. Columns 3 and 4 include 70 region fixed effects. See data appendix for details on the construction of our variables. 
TABle 7: Heterogeneous Effects

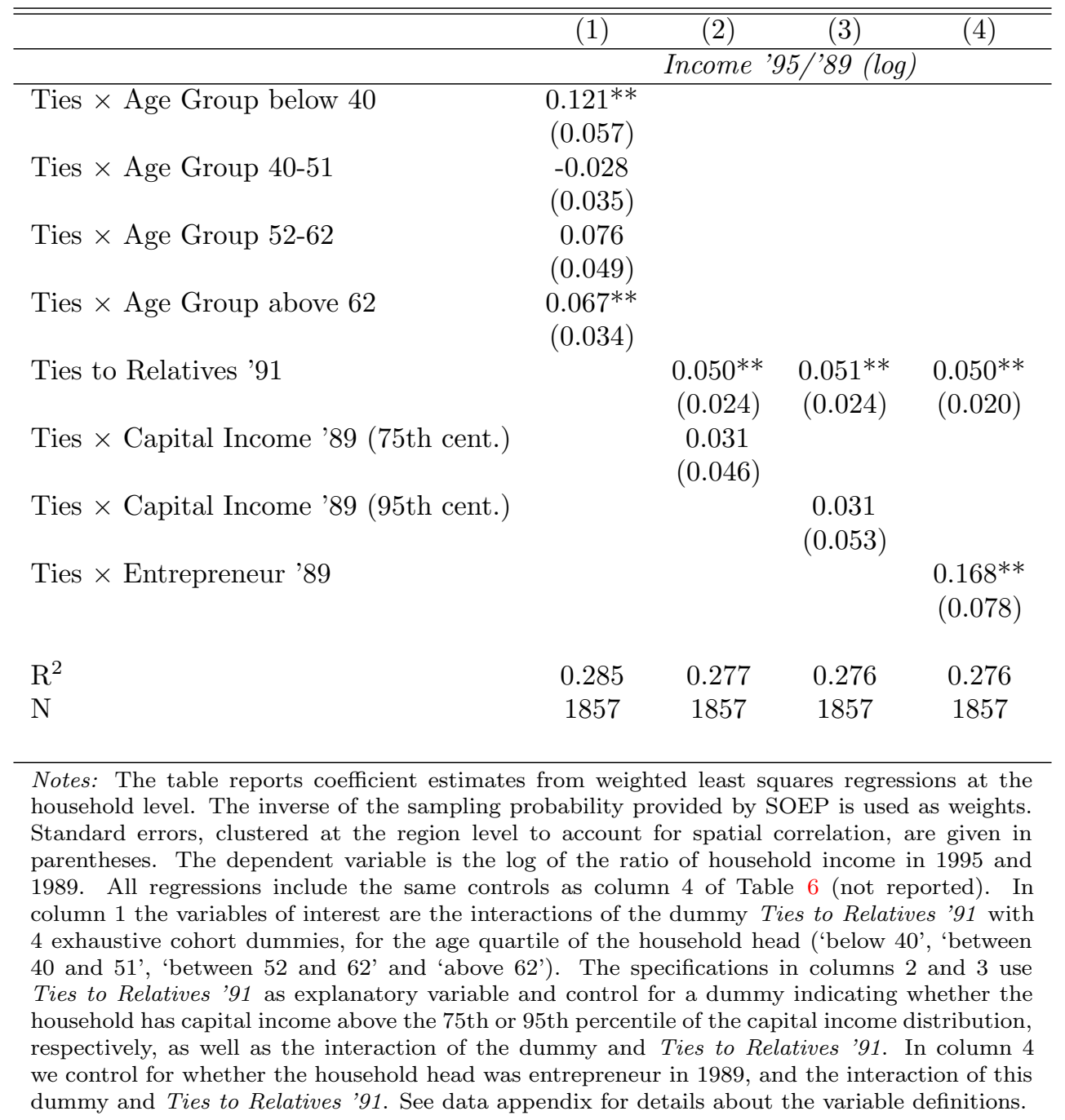




\title{
Online Appendix
}

\author{
'The Economic Effects of Social Ties: \\ Evidence from German Reunification'
}

Konrad B. Burchardi

Tarek A. Hassan

\section{A The Effect of Direct and Indirect Expellees on Eco- nomic Growth}

This appendix describes in detail the placebo test comparing the economic effect of the presence of direct expellees to that of expellees via the Soviet sector in Section 4.4. Both groups of expellees arrived from the parts of pre-war Germany that were annexed by Poland and Russia, and ultimately settled in West Germany. The placebo experiment uses direct expellees as a control group of migrants who have the same geographic origin as expellees via the Soviet sector, but who did not have the opportunity to form social ties to East Germany.

\section{A.1 Direct Expellees as a Control Group}

In the following, we argue that direct expellees are a good 'control group' for the effect of expellees via the Soviet Sector for three reasons.

First, the two groups of expellees look similar on observable socio-economic characteristics, such as educational attainment, occupational structure, and labor force participation. Appendix Table 3 shows the relevant descriptive statistics for both groups taken from the 1971 census, which is the last census in which the two groups are separately identified.

Second, the economic integration between the unified Germany and other Eastern European countries remained low in the early 1990s, such that the economic value of social ties to the regions of origin of the direct expellees must have been low relative to the economic value of social ties to East Germany. Within four years exports from West Germany to East Germany rose from DM 7bn in 1988 to DM 69bn in 1994. Exports to East Germany thus rapidly exceeded exports to France (DM 67bn in 1994), which had been the number one export market of West German firms prior to the fall of the Berlin Wall. Compared to East Germany, both the rise and the total volume of exports to Poland and the Czech Republic remained small, rising from around 2.5bn in 1988 to around 7.5bn in $1994 .{ }^{40}$ In this sense, the trade response to the fall of the Berlin Wall is a prime example of the "Border Effect" (McCallum (1995)), which posits that the volume of trade within a country is an order of magnitude larger than trade across countries.

Third, the extent to which migration results in the establishment of social ties across regions depends crucially on the share of the population that remains in the region of origin. While it is difficult to estimate the share of the 1939 population and their descendants that remained

\footnotetext{
${ }^{40}$ Data on exports to East Germany as well as to Poland and Czech Republic before 1989 are from Nitsch (2002). Data for exports to Poland and Czech Republic post 1989 from Statistisches Bundesamt.
} 
residents of the same region, it seems clear that this share is close to one in East Germany whereas it is close to zero for Pommern, Schlesien, and East Prussia. As a consequence, we expect the probability that a given direct expellee would have relatives or friends in Poland or the Czech Republic to be an order of magnitude lower than the probability that a given expellee via the Soviet sector would have relatives or friends in East Germany.

In sum, we expect expellees to be much less likely to retain social ties to to Poland and the Czech Republic than to East Germany and expect any surviving ties to be less relevant for economic exchange due to persistent barriers to trade across borders prior to EU accession in 2004. For this reason we are not surprised that the effect of direct expellees on changes in the growth rate of income per capita between 1989 and 1995 is statistically indistinguishable from zero once we control for the share of expellees via the Soviet Sector. While the settlement of both direct expellees and expellees via the Soviet sector predicts firm investment in Poland and the Czech Republic, this effect is much smaller than the effect on investment in East Germany and may have occurred post 2004 rather than post 1989.

\section{A.2 Systematic Differences between Regions with Concentrations of Direct and Indirect Expellees}

A potential concern with our placebo test is that regions with differential concentrations of direct and indirect expellees might be systematically different in other ways, which might correlate with differential economic growth post 1989.

Appendix Table 4b explores this possibility by regressing seven region characteristics in 1989 on the share direct and indirect expellees in 1961 and our standard region level controls (distance to East, income in 1989, income growth between 1985 and 1989, and state fixed effects). Each line of the table corresponds to one regression. The table reports the dependent variable, the coefficients on the two groups of expellees, as well as the $p$-value corresponding to the null hypothesis that the two coefficients are equal. We cannot reject this hypothesis at the $5 \%$ level in any of the seven specifications.

However, we reject the null hypothesis that regions with a larger share of direct expellees have the same share of their workforce employed in the agricultural sector at the $10 \%$ level. We therefore control for the employment share in agriculture and the employment shares of the three other sectors when implementing the placebo test.

\section{A.3 Placebo Test}

The placebo test makes the following argument: If we misinterpret our key region level results and the effects we document are driven by some omitted variable which determined both wartime destruction and changes in post 1989 income growth, or if there was something special about expellees per se that gave them access to business opportunities post 1989, we would expect to find that both groups of expellees have an identical effect on income growth post 1989.

Appendix Table 5 shows the placebo test in which we relate growth in income per capita post 1989 simultaneously to the share of expellees via the Soviet sector and to the share of direct expellees, again conditional on our standard region level controls (not shown). Column 1 gives the results from an OLS regression. While the coefficient on expellees via the Soviet Sector is positive, statistically significant at the $1 \%$ level, and very similar to the estimates from Table 3 $(2.131$, s.e. $=0.701)$, the coefficient on the share of direct expellees is negative and statistically 
indistinguishable from zero. In columns 2 and 3 we add additional controls for the share of the population employed in agriculture (column 2) and for the share of the population employed in the other three sectors (column 3). Both make little difference to the results.

In columns 4-6 we repeat this exercise using our instrumental variables strategy. To compare the causal effect of direct expellees and expellees via the Soviet sector on income growth post 1989 we require two instruments which give us differential leverage in identifying the exogenous components in the settlement patterns of both groups. In Panels B and $\mathrm{C}$ we re-run our standard first stage regression from Table 2 column 2, but include both the share of housing destroyed and the volume of rubble per capita in 1946. (We again do not report covariates in the interest of space.) Panel B gives the results for expellees arriving via the Soviet sector and Panel C gives the results for direct expellees. In the case of the former, the share of housing destroyed is significant with a negative sign and rubble is insignificant across all three specifications. In the case of the latter, the size of the effect of the share of housing destroyed is roughly preserved, though it is less precisely estimated. Importantly for us, the coefficient on the amount of rubble is negative and significant. Our two measures of wartime destruction thus give us differential leverage in identifying the exogenous components in the settlement patterns of both groups.

This feature of the data may be related to the timing of the arrival of the two groups of expellees. The direct expellees arrived immediately after the war, whereas the expellees via the Soviet sector arrived between 1945 and 1961. We therefore suspect that rubble per capita measures a dimension of wartime damage which was more important in the immediate aftermath of the war but was then cleared away relatively quickly, while the destruction of the housing stock had longer-lasting effects.

The Kleibergen-Paap rank test allows us to formally test whether the two instruments induce sufficient differential variation in the endogenous variables. The Kleibergen-Paap LM statistic is 3.95. Hence, we reject the null that the matrix of reduced form coefficients is underidentified at the $5 \%$ level.

Using both instruments, we are thus able to separately estimate the causal effects of expellees via the Soviet sector and of direct expellees on differential income growth after 1989. Columns 1-3 of Panel A present the results. While the coefficient on the share of expellees via the Soviet sector is again positive, similar in magnitude to the estimates obtained earlier $(3.422$, s.e.= 1.809 in column 1), and statistically significant at the $10 \%$ level, the coefficient on the share of direct expellees is close to zero and statistically insignificant. The two coefficients are statistically significantly different in the specification shown in column 1 ( $p$-value: 0.008 ). In the instrumental variable specification of column 4 the $p$-value is 0.117 .

\section{B Robustness of Region Level Results}

\section{B.1 Regional Growth Betas}

A potential concern with our region level results is that West German regions with a high concentration of expellees via the Soviet sector might for some reason have a larger exposure to the West German business cycle. To address this concern we use our data on income per capita prior to 1990 (we have data for 1982, 1984, 1986, 1987, and 1989) to estimate a "growth beta" for each West German region by regressing its growth rate in income per capita on country level income growth in each year between 1982 and 1989. In a second step (reminiscent of a FamaMacBeth procedure) we include this estimate of the growth beta in our standard specification. 
Appendix Table 6 tabulates the results. Column 1 shows results from an ordinary least squares regression (corresponding to column 2 of Panel A in Table 3). Columns 2 and 3 show results from instrumental variable regressions (corresponding to column 3 of Panel A in Table 3), where column 3 additionally weights each observation with the inverse of the standard error of the estimate of its growth beta. The coefficient estimate on the growth beta is close to zero and negative in all columns. It is statistically significant only in the weighted specification in column 3 , while the coefficients of interest are virtually unchanged relative to the estimates in Table 3 . It thus appears that the growth beta has little additional explanatory power for income growth in the period between 1989 and 1995 once the pre-trend in income growth is controlled for. The regional economic expansion which we attribute to the pattern of social ties existing in 1989 is thus unrelated to the loadings of different regions on the West German business cycle.

\section{B.2 Systematic Differences between Regions}

We test for systematic differences between regions with high and low wartime destruction by regressing seven region characteristics in 1989, including the average educational attainment, the share of the population who are entrepreneurs, the unemployment rate, and the sectoral composition of the workforce on the share of housing destroyed in 1946 and our standard region level controls. The results in Appendix Table 4a show that the pattern of wartime destruction is not significantly correlated with any of these observable region characteristics. Each line of the table corresponds to one regression. It reports the dependent variable, the coefficient on Share Housing Destroyed ' 46 , as well as the $p$-value corresponding to the null hypothesis that the coefficient is equal to zero. We cannot reject this hypothesis at the $5 \%$ level in any of the seven specifications.

\section{B.3 Restitutions}

A final concern for which we cannot control explicitly at the regional level is that expellees via the Soviet sector might be more likely than 'native' West Germans and direct expellees to have restitution claims to property expropriated in East Germany. Under the reunification treaty, former owners of assets located in East Germany could apply for restitution or compensation providing that they had not received compensation from the East German government and that the assets they were claiming still existed at the time of filing. This meant that practically all individual claims filed related to real estate or firms. While compensation payments by law did not begin until 1996 (Southern, 1993), the restitution of assets began in the early 1990s and could potentially confound our measure of income per capita. However, we can be confident that any bias they may induce in our estimates is quantitatively small. ${ }^{41}$

First, the Mikrozensus asks about household income in a usual month and respondents select an income bracket (with the highest category being DM 7000 in 1995), so that one-time inflows of cash have no impact on our measure of income per capita. The only potential concern for our results is therefore any flow income that may be generated by restituted assets (or by assets purchased from proceeds of sales of restituted assets).

\footnotetext{
${ }^{41}$ According to the government agency handling restitutions, half of all approved claims were settled by compensation payments, and the total sum of compensation payments made between 1996 and 2009 was EUR 1.4 bn. (Personal correspondence with Dr. Händler, press liaison of the Bundesamt für zentrale Dienste und offene Vermögensfragen.)
} 
Second, the volume of restitutions was orders of magnitude smaller than the effect on income per capita we document in the main text. For example, the average East German rental unit generated a monthly cash flow of DM 240 in 1995. (Average rent paid in East Germany per month in 1995 excluding utilities is DM 437 (Deutsches Institut fur Wirtschaftsforschung, 1996). According to a survey of large operators of rental apartments and houses (GdW Bundesverband deutscher Wohnungs- und Immobilienunternehmen, 1994), maintenance and renovations accounted for $45 \%$ of rental revenues in 1993 such that we may estimate the cash flow per unit as $(.55) 437=240$.) If we estimate that about 300,000 apartments and houses were returned to former West German owners by $1995^{42}$ and made the extreme assumption that all of these units went to expellees via the Soviet sector, the average expellee would experience a rise in her monthly income of DM $240 \frac{300,000}{2,800,000}=$ DM 25.71. A one standard deviation increase in the share of expellees (0.019) would then be associated with a rise in income per capita at the regional level of DM 0.49 (or $0.03 \%$ ). Similarly, a reasonable estimate of the total value of the 1,571 firms restituted to their former owners by 1994 is DM $9.7 \mathrm{bn} .{ }^{43}$ If we again made the extreme assumption that all of these firms were restituted to expellees via the Soviet sector, and that they immediately generated an annual cash flow of $10 \%$ (which they almost certainly did not as the average recipient of a firm had a contractual obligation to make investments amounting to two times the estimated firm value in the five years following privatization (Lange and Pugh, 1998, p. 73)), the average expellee would experience a rise in her monthly income of DM $\frac{9.7 b n}{2,800,000} \frac{0.1}{12}=$ DM 28.87. A one standard deviation increase in the share of expellees would then be associated with a rise in income per capita of a mere $0.03 \%$. The volume of restitutions made before 1995 was therefore orders of magnitude too small to induce a meaningful bias in our estimates.

\section{B.4 Proximate Interpretations}

A remaining concern with the interpretation of our results is that migrants arriving from East Germany may have had an unobservable emotional affinity to the East that direct expellees did not share. Such an emotional affinity may have prompted them to accept lower expected returns when investing in the East and, by pure chance, realized returns may have been so much higher than expected that they resulted in a rise in income per capita at the regional level. Conceptually, we cannot rule out this possibility. However, the idea that realized returns of investing in the East were a large positive surprise would be grossly at odds with the dominant narrative that economic performance of the East post reunification was a significant disappointment (see for example Paque (2009)).

Relatedly, some of the patterns we document may be explained if migrants from the East had permanently different consumption preferences than 'native' West Germans and if these preferences were more similar to the consumption preferences of East Germans post reunification (Atkin (2010) documents such long-lasting differences in preferences for India). However, we have found no mention of such differences in the literature on inner-German migration, and

\footnotetext{
${ }^{42}$ (Hubert and Tomann, 1993) estimate that a maximum of $1,3 \mathrm{~m}$ apartments and houses were affected by restitution claims. Approximately $60 \%$ of all restitution claims were made by West Germans (Thimann, 1996, p. 147). By the end of 1993, 20\% of rental properties which had been claimed by former owners had been restituted GdW Bundesverband deutscher Wohnungs- und Immobilienunternehmen (1994).

${ }^{43}$ The Treuhandanstalt, the government body administering the privatization of East German firms, generated a total of DM 60bn in revenues from the sale and liquidation of 10,428 firms (or DM 6.2m per firm). Assuming that the 1,571 restituted firms had the same average value and that they were returned to their former owners for free, the total value of firm restitutions amounts to DM 9.7bn (Lange and Pugh, 1998, p. 73).
} 
the literature on German Reunification actually suggests the opposite: that East Germans immediately abandoned East German consumption brands in favor of West German brands (Sinn and Sinn, 1992). In line with this view, East and West German CPI are today calculated using identical weights.

\section{Robustness of Household Level Results}

\section{C.1 Additional Controls}

We add the share of households who are employed in the government sector as an additional control to our standard specification in Panel A of Appendix Table 9. The coefficient of interest rises slightly to 0.061 (s.e. $=0.021$ ) and remains statistically significant at the $1 \%$ level. The following columns add the household head's years of education and years of education squared in 1989 and a dummy variable for whether the household head is an entrepreneur in 1989. These additional controls remain insignificant, and induce almost no change in the coefficient of interest.

While social ties to East Germany may generate significant economic benefits to West German households post 1989, they may also entail a moral obligation to financially support these relatives in the long term. Indeed, households with social ties to the East report paying significantly higher transfers to relatives between 1989 and 1995, but do not receive higher transfers from relatives than comparable other households (see Panel B of Appendix Table 10). Consistent with this observation, our results remain unchanged when we control for the volume of the transfers received from relatives between 1990 and 1995 (Panel A of Appendix Table 9). ${ }^{44}$

\section{C.2 Restitutions}

In Panel B of Appendix Table 9 we check the robustness of our results using a restricted sample of households which excludes all households who may potentially have received restitutions of assets from the East: It excludes all households who have rental income in 1995 as well as all households who owned firms in 1995 but not in 1989. ${ }^{45}$ Throughout the panel, the coefficient estimates are statistically significant at the $1 \%$ level and very similar to those we obtain in the full sample. The data are thus consistent with the view that the effect of restitutions on income growth, particularly pre 1995, is economically small.

\section{C.3 Propensity Score Matching}

As an additional robustness check we re-estimate our results using a propensity score matching estimator. We estimate the propensity of treatment by running a probit regression of our dummy indicating ties to the East on the controls used in Table 9. We then calculate the predicted probability that each household in our sample has ties to the East and group our observations into 5 bins corresponding to 20 percentage point probability intervals. In a second step, we regress the growth of household income between 1989 and 1995 on a full set of fixed effects for each bin and on the interactions between these fixed effects and our dummy indicating ties to

\footnotetext{
${ }^{44}$ See Martinez and Yang (2007) for an example in which variation in the transfers paid by migrants to households in their regions of origin affect economic outcomes at the regional level.

${ }^{45} \mathrm{~A}$ total of 57 households in our sample acquired firms between 1989 and 1995, 17 of which had relatives in East Germany.
} 
the East. The estimated average treatment effect across bins (weighted by the probability mass of households in each bin) is 0.048, which is only slightly smaller than our estimates in Table 9 . If the conditional independence assumption holds, adding controls to this regression should have very little impact on the result. When we include the controls from Table 9 as additional controls the estimated effect changes only slightly to 0.058 . 


\section{References in Online Appendix}

Atkin, D. (2010). Trade, tastes and nutrition in india. Yale University Economic Growth Center Discussion Paper No. 986.

Deutsches Institut fur Wirtschaftsforschung (1996). Wochenbericht 22.

GdW Bundesverband deutscher Wohnungs- und Immobilienunternehmen (1994). Daten und fakten 1993 der untenehmerischen wohnungswirtschaft in den neuen laendern. Informationen.

Hubert, F. and H. Tomann (1993). Wohnungspolitischer umbruch in ostdeutschland. Nachdruck einer Studie im Auftrage des Bundesbauministeriums vom Februar 1993.

Lange, T. and G. Pugh (1998). The Economics of German Reunification. Edward Elgar, Cheltenham UK and Northampton MA.

Martinez, C. and D. Yang (2007, August). Remittances and poverty in migrants' home areas: Evidence from the philippines. University of Chile, Department of Economics, Working Papers $25 \%$.

McCallum, J. (1995). National borders matter: Canada-u.s. regional trade patterns. The American Economic Review 85(3), pp. 615-623.

Nitsch, V. (2002). Border effects and border regions: Lessons from the german unification. Hamburg Institute of International Economics Discussion Paper 203.

Paque, K.-H. (2009). Die Bilanz. Carl Hanser Verlag Muenchen.

Sinn, G. and H.-W. Sinn (1992). Jumpstart. MIT Press, Cambridge MA.

Southern, D. B. (1993). Restitution or compensation: The land question in east germany. The International and Comparative Law Quarterly 42(3), 690-697.

Thimann, C. (1996). Aufbau von Kapitalstock und Vermoegen in Ostdeutschland. J.C.B. Mohr (Paul Siebeck) Tuebingen. 


\section{Appendix Tables}

Appendix Table 1 - Data Description and Sources

\begin{tabular}{|c|c|c|}
\hline Variable & Description & Source \\
\hline \multicolumn{3}{|l|}{ PANEL A: Original variables } \\
\hline Share Expellees (Sov. Sector) '61 & $\begin{array}{l}\text { Share of the total region/district population in } 1961 \\
\text { that is made up by expellees from the former Eastern } \\
\text { territories of the German Reich who settled in the So- } \\
\text { viet sector before arriving in Western Germany (the } \\
\text { Western sectors). The exact census definition of this } \\
\text { group is given in Statistisches Bundesamt (1961), } \\
\text { p.4. }\end{array}$ & 1961 Census \\
\hline Share Expellees (Direct) '61 & $\begin{array}{l}\text { Share of the total region/district population in } 1961 \\
\text { that is made up by expellees from the former East- } \\
\text { ern territories of the German Reich who did not set- } \\
\text { tle in the Soviet sector before arriving in Western } \\
\text { Germany (the Western sectors). The exact census } \\
\text { definition of this group is given in Statistisches Bun- } \\
\text { desamt (1961), p.4. }\end{array}$ & 1961 Census \\
\hline Share Ties to Relatives '91 & $\begin{array}{l}\text { The respondents were asked whether they had rela- } \\
\text { tives in the other part of Germany. We calculated } \\
\text { the share of people who responded affirmatively. }\end{array}$ & SOEP (1991) \\
\hline Subsidiaries and Branches in $l o c^{a}$ & $\begin{array}{l}\text { Number of subsidiaries and branches registered in } \\
\text { loc belonging to the firm. }\end{array}$ & ORBIS (2007) \\
\hline Share of Housing Destroyed '46 & $\begin{array}{l}\text { Destroyed apartments and houses in } 1946 \text { as a share } \\
\text { of the stock of apartments and houses in } 1939 .\end{array}$ & $\begin{array}{l}\text { German Association of } \\
\text { Cities (1949) }\end{array}$ \\
\hline Rubble'46 (m³ p.c.) & Untreated rubble in 1946 in cubic meters per capita. & $\begin{array}{l}\text { German Association of } \\
\text { Cities (1949) }\end{array}$ \\
\hline Income $t$ (p.c., log, MZ) & $\begin{array}{l}\text { Log of average income in Deutsche Mark. This infor- } \\
\text { mation is not publicly available at the region level. } \\
\text { We have extracted it from the German Mikrozensus, } \\
\text { a yearly survey of a random } 1 \% \text { sample of the pop- } \\
\text { ulation. The question used asks for the household's } \\
\text { monthly income per household member in May and } \\
\text { the respondent selects an income bracket into which } \\
\text { his household falls. To convert this categorical vari- } \\
\text { able into a continuous variable, we use the mean } \\
\text { of the bounds of the brackets to calculate the av- } \\
\text { erage income per household member and aggregate } \\
\text { to the region level. For the top income bracket no } \\
\text { upper bound exists. We extrapolate linearly from } \\
\text { the second-highest income bracket. E.g for } 1985 \text { the } \\
\text { second-highest income bracket is ' } 4500 \text { to } 5000 \text { Ger- } \\
\text { man Marks'. Hence we assign to households in the } \\
1985 \text { top income bracket (' } 5000 \text { German Marks or } \\
\text { more') a monthly income of } 5250 \text { German Marks. }\end{array}$ & $\begin{array}{l}\text { German Mikrozensus } \\
(1985, \quad 1987, \quad 1989, \\
1991,1993,1995)\end{array}$ \\
\hline $\begin{array}{l}\text { Income Entrepreneurs } t \text { (p.c., } \\
\log )\end{array}$ & $\begin{array}{l}\text { Log average income in Deutsche Mark for the } \\
\text { subgroup of individuals who indicated to be 'en- } \\
\text { trepreneur' (with or without employees). }\end{array}$ & $\begin{array}{l}\text { German Mikrozensus } \\
(1989,1995)\end{array}$ \\
\hline $\begin{array}{l}\text { Income Non-Entrepreneurs } t \\
\text { (p.c., log) }\end{array}$ & $\begin{array}{l}\text { Log average income in Deutsche Mark for the sub- } \\
\text { group of individuals who indicated to have an oc- } \\
\text { cupation other than 'entrepreneur' (with or without } \\
\text { employees). }\end{array}$ & $\begin{array}{l}\text { German Mikrozensus } \\
(1989,1995)\end{array}$ \\
\hline
\end{tabular}


Appendix TABle 1 - CONTINUed from previous Page

\begin{tabular}{|c|c|c|}
\hline Variable & Description & Source \\
\hline Share Entrepreneur $t$ & $\begin{array}{l}\text { Regional share of individuals who indicate that they } \\
\text { are an entrepreneur (with or without employees). }\end{array}$ & $\begin{array}{l}\text { German Mikrozensus } \\
(1989)\end{array}$ \\
\hline Share Employed in $x$ ' 89 & $\begin{array}{l}\text { Regional share of individuals who indicate to be } \\
\text { working in sector } x \text {. }\end{array}$ & $\begin{array}{l}\text { German Mikrozensus } \\
(1989)\end{array}$ \\
\hline Distance to East $(100 \mathrm{~km})$ & $\begin{array}{l}\text { Closest distance from a region's center to the former } \\
\text { GDR border in } 100 \mathrm{~km} \text {. }\end{array}$ & - own calculations - \\
\hline Migration from East '91-'95 & $\begin{array}{l}\text { Sum of the share of surveyed individuals who mi- } \\
\text { grated to the region in the years 1991, } 1993 \text { and } \\
1995 \text { from East Germany. }\end{array}$ & $\begin{array}{l}\text { German Mikrozensus } \\
(1991,1993,1995)\end{array}$ \\
\hline Ties to Relatives '91 (Dummy) & $\begin{array}{l}\text { Dummy indicating whether household head or an- } \\
\text { other person in the same household had relatives in } \\
\text { the other part of Germany in } 1991 \text {. }\end{array}$ & German SOEP (1991) \\
\hline Income $t(\log , \mathrm{SOEP})$ & $\begin{array}{l}\text { Log of income in German Mark (plus 1) of household } \\
\text { head in year } t \text {. }\end{array}$ & German SOEP \\
\hline Gender & Gender of the household head (0: male, 1: female). & German SOEP (1989) \\
\hline Age '90 & Age of household head in 1990. & German SOEP (1989) \\
\hline Years of Education '89 & $\begin{array}{l}\text { Years of education (including professional educa- } \\
\text { tion) of highest ranked individual in the household } \\
\text { for whom income data exists. Usually this will be } \\
\text { the household head. }\end{array}$ & German SOEP (1989) \\
\hline Capital Income '89 & Log of household capital income (plus 1) in 1989. & German SOEP (1989) \\
\hline Occupation '89 & $\begin{array}{l}\text { We aggregated the occupations given in the German } \\
\text { SOEP to the } 8 \text { categories 'Not Employed', 'Pen- } \\
\text { sioner', 'In Education/Military Service', 'Worker', } \\
\text { 'Farmer', 'White Collar', 'Entrepreneur' and 'Civil } \\
\text { Servant'. }\end{array}$ & German SOEP (1989) \\
\hline Industry Sector '89 & $\begin{array}{l}\text { This uses information on the industrial sector in } \\
\text { which the household head works, given in the Ger- } \\
\text { man SOEP. We aggregated the sectors into the } 4 \\
\text { categories 'Agriculture', 'Manufacturing', 'Services', } \\
\text { and 'Government'. }\end{array}$ & German SOEP (1989) \\
\hline Ownership of Assets $t$ (D) & $\begin{array}{l}\text { Two dummy variables indicating whether the house- } \\
\text { hold owns 'Financial Securities' and 'Operating As- } \\
\text { sets' in year } t \text {. }\end{array}$ & German SOEP \\
\hline Sources of Income '89 & $\begin{array}{l}\text { Four variables indicating the natural logarithm of } \\
\text { the household income in German Mark from four } \\
\text { sources (plus 1): 'Entrepreneurial Activity', 'Em- } \\
\text { ployment', 'Profit Share', and 'Financial Securities'. }\end{array}$ & German SOEP (1989) \\
\hline Affiliations '89 & $\begin{array}{l}\text { Two dummy variables which indicate 'Union Mem- } \\
\text { bership' and 'Membership in a Professional Associ- } \\
\text { ation' of the household head. }\end{array}$ & German SOEP (1989) \\
\hline Transfers from Relatives $t(\log )$ & $\begin{array}{l}\text { The natural logarithm of the amount (plus 1) of } \\
\text { transfers in German Marks the household received } \\
\text { from relatives in year } t \text {. }\end{array}$ & German SOEP \\
\hline Transfers to Relatives $t(\log )$ & $\begin{array}{l}\text { The natural logarithm of the amount (plus } 1 \text { ) of } \\
\text { transfers in German Marks paid to relatives (other } \\
\text { than parents and children) in year } t \text {. }\end{array}$ & German SOEP \\
\hline
\end{tabular}


Appendix TABle 1 - CONTINUED From PREVious PAGE

\begin{tabular}{l|l|l}
\hline Variable & Description & Source \\
\hline Concern about $s$ '90 & The level of concern the household head has about & German SOEP (1990) \\
& topic $s$, where $s$ is 'Aggregate Economic Develop- & \\
& ment', 'Preservation of Peace', and 'Individual Job & \\
& Security'. All three variables take values 1,2, or 3, & \\
& with 1 being the most concerned and 3 being the & \\
\hline & least concerned. & \\
\hline
\end{tabular}

PANEL B: Generated variables

\begin{tabular}{|c|c|c|}
\hline Income $t_{1} / t_{0}$ (p.c., log) & Income $t_{1}$ (p.c., log) - Income $t_{0}$ (p.c., $\log$ ). & \\
\hline $\begin{array}{l}\text { Share of Total Subsidiaries and } \\
\text { Branches in } l o c^{a}\end{array}$ & $\begin{array}{l}\text { Number of subsidiaries and branches in loc over } \\
\text { the sum of this and the number of subsidiaries and } \\
\text { branches in West Germany. }\end{array}$ & \\
\hline $\begin{array}{l}\text { Subsidiaries and Branches in } l o c^{a} \\
\text { (Dummy) }\end{array}$ & $\begin{array}{l}\text { Dummy variable that indicates whether the firm op- } \\
\text { erates at least one subsidiary or branch in loc. }\end{array}$ & \\
\hline $\begin{array}{l}\text { Subsidiaries and Branches in } l o c^{a} \\
(\log )\end{array}$ & $\begin{array}{l}\text { Logarithm of the number of subsidiaries and } \\
\text { branches in loc. }\end{array}$ & \\
\hline Income $t$ (p.c., log, SOEP) & $\begin{array}{l}\text { Log of average income in the region, using the SOEP } \\
\text { data. }\end{array}$ & \\
\hline Income $t_{1} / t_{0}(\log , \mathrm{SOEP})$ & $\begin{array}{l}\text { Income } t_{1} \text { (p.c., log, SOEP) - Income } t_{0} \text { (p.c., log, } \\
\text { SOEP) }\end{array}$ & \\
\hline $\begin{array}{l}\text { Transfers from Relatives '90-'95 } \\
(\log )\end{array}$ & $\begin{array}{l}\text { The natural logarithm of the nominal sum (plus 1) } \\
\text { in German Marks of Transfers from Relatives over } \\
\text { the years } 1990,1991,1993 \text { and } 1995 \text {. }\end{array}$ & \\
\hline $\begin{array}{l}\text { Transfers to Relatives '90-'95 } \\
(\log )\end{array}$ & $\begin{array}{l}\text { The natural logarithm of the nominal sum (plus 1) } \\
\text { in German Marks of Transfers to Relatives over the } \\
\text { years 1990, 1991, } 1993 \text { and } 1995 \text {. }\end{array}$ & \\
\hline
\end{tabular}

${ }^{a}$ Where loc stands for East Germany, West Germany, 'New' EU Countries, 'Old' EU Countries, and Non-EU Countries. 
Appendix Table 2: GMM Using Panel Structure

\begin{tabular}{|c|c|c|c|}
\hline & $(1)$ & $(2)$ & $(3)$ \\
\hline & \multicolumn{3}{|c|}{ Income (p.c., log) } \\
\hline Share Expellees × 1995 & $\begin{array}{c}2.800^{* * *} \\
(0.984)\end{array}$ & $\begin{array}{c}2.839^{* * *} \\
(0.907)\end{array}$ & $\begin{array}{c}2.528^{* * *} \\
(0.854)\end{array}$ \\
\hline Share Expellees $\times 1993$ & $\begin{array}{r}2.046^{* *} \\
(0.984)\end{array}$ & $\begin{array}{l}2.085^{* *} \\
(0.907)\end{array}$ & $\begin{array}{l}1.774^{* *} \\
(0.854)\end{array}$ \\
\hline Share Expellees $\times 1991$ & $\begin{array}{l}1.519 \\
(0.984)\end{array}$ & $\begin{array}{l}1.558^{*} \\
(0.907)\end{array}$ & $\begin{array}{c}1.247 \\
(0.854)\end{array}$ \\
\hline Share Expellees $\times 1989$ & $\begin{array}{c}0.493 \\
(0.984)\end{array}$ & $\begin{array}{c}0.532 \\
(0.907)\end{array}$ & \\
\hline Share Expellees $\times 1987$ & $\begin{array}{l}-0.342 \\
(0.984)\end{array}$ & & \\
\hline Income 1985 (p.c., log) & $\begin{array}{c}0.853^{* * *} \\
(0.032)\end{array}$ & & \\
\hline Income 1987 (p.c., log) & & $\begin{array}{c}0.834^{* * *} \\
(0.033)\end{array}$ & \\
\hline Income '87/'85 (p.c., log) & & $\begin{array}{c}-0.473^{* * *} \\
(0.061)\end{array}$ & \\
\hline Income 1989 (p.c., log) & & & $\begin{array}{c}0.829^{* * *} \\
(0.037)\end{array}$ \\
\hline Income '89/'85 (p.c., log) & & & $\begin{array}{c}-0.466^{* * *} \\
(0.060)\end{array}$ \\
\hline Distance East $(100 \mathrm{~km})$ & $\begin{array}{c}0.003 \\
(0.003)\end{array}$ & $\begin{array}{c}0.006^{* *} \\
(0.003)\end{array}$ & $\begin{array}{c}0.005 \\
(0.003)\end{array}$ \\
\hline $\mathrm{N}$ & 350 & 280 & 210 \\
\hline
\end{tabular}

Notes: The table reports coefficient estimates from an asymptotically efficient two-step GMM estimation. In the first step we applied the Bartlett kernel to estimate the covariances of the errors up to one lag. The dependent variable is the log of mean per capita income in year $t$, where $t$ is 1991,1993 and 1995. In column 2 we additionally use data from 1989 , and in column 1 data from 1987 as outcome variable. The main variable of interest in all columns is Share Expellees (Soviet Sector) '61. We interacted this with a full set of possible year dummies (different across columns) and hence the main effect is not included. We instrument for these interactions with the interaction of the same year dummies with Share Housing Destroyed '46. All regressions control for a region's distance to the inner-German border and include state-year fixed effects. Column 1 controls for the log of the mean per capita income in 1985, column 2 controls for the log of the mean per capita income in 1987 and column 3 controls for the log of the mean per capita income in 1989. Column 2 also controls for log of the ratio of mean per capita income in 1987 and 1985. Column 3 also controls for log of the ratio of mean per capita income in 1989 and 1985. 
Appendix Table 3: Summary Statistics (Expellees, Census '71)

\begin{tabular}{|c|c|c|c|}
\hline & $\begin{array}{c}(1) \\
\text { Ex. (Soviet Sector) }\end{array}$ & $\begin{array}{ll} & (2) \\
E x . & (\text { Direct })\end{array}$ & $\begin{array}{c}(3) \\
\text { West Germans } \\
\end{array}$ \\
\hline Years of Schooling '71 & $\begin{array}{c}9.69 \\
(1.19)\end{array}$ & $\begin{array}{c}9.63 \\
(1.11)\end{array}$ & $\begin{array}{c}9.81 \\
(1.50)\end{array}$ \\
\hline Share Entrepreneur ' 71 & 0.03 & 0.03 & 0.06 \\
\hline Labor Force Participation '71 & 0.52 & 0.54 & 0.55 \\
\hline Agriculture '71 & 0.04 & 0.05 & 0.12 \\
\hline Manufacturing '71 & 0.51 & 0.53 & 0.44 \\
\hline Services '71 & 0.33 & 0.30 & 0.32 \\
\hline Government '71 & 0.12 & 0.13 & 0.11 \\
\hline $\mathrm{N}$ & 10120 & 49638 & 322240 \\
\hline \multicolumn{4}{|c|}{$\begin{array}{l}\text { Notes: Appendix Table } 3 \text { shows means, standard deviations in parentheses. Data is from the } 1971 \\
\text { edition of the German Census. Column } 1 \text { shows summary statistics for expellees via the Soviet } \\
\text { sector. Column } 2 \text { shows summary statistics for direct expellees. Column } 3 \text { shows data for all } \\
\text { remaining individuals excluding refugees. Income in } 1971 \text { is given in nominal Deutsche Mark. Labor } \\
\text { force participation and share entrepreneur are given relative to the entire population. The sectoral } \\
\text { distribution is given relative to all working individuals. }\end{array}$} \\
\hline
\end{tabular}


Appendix Table 4: Direct Expellees and Expellees via Soviet Sector (a) War Destruction and Regional Characteristics '89

\begin{tabular}{|c|c|c|}
\hline & (1) & $(2)$ \\
\hline Outcome Variable & $\begin{array}{c}\text { Coefficient } \\
\text { Share Housing Destr. ' } 46\end{array}$ & $\begin{array}{c}p \text {-value } \\
\left(H_{0}: \text { No Conditional Corr. }\right)\end{array}$ \\
\hline Years of Schooling '89 & $\begin{array}{c}0.053 \\
(0.089)\end{array}$ & 0.553 \\
\hline Share Entrepreneur '89 & $\begin{array}{l}-0.006 \\
(0.006)\end{array}$ & 0.304 \\
\hline Share Unemployed '89 & $\begin{array}{c}0.004 \\
(0.005)\end{array}$ & 0.397 \\
\hline Sh. Employed in Agriculture '89 & $\begin{array}{l}-0.012 \\
(0.008)\end{array}$ & 0.122 \\
\hline Sh. Employed in Manufacturing '89 & $\begin{array}{c}0.000 \\
(0.026)\end{array}$ & 0.989 \\
\hline Sh. Employed in Services '89 & $\begin{array}{c}0.013 \\
(0.014)\end{array}$ & 0.362 \\
\hline Sh. Employed in Government ' 89 & $\begin{array}{l}-0.006 \\
(0.013)\end{array}$ & 0.616 \\
\hline
\end{tabular}

(B) Expellee Settlement and Regional Characteristics '89

\begin{tabular}{|c|c|c|c|}
\hline \multirow[b]{3}{*}{ Outcome Variable } & $(1)$ & \multirow[t]{2}{*}{$(2)$} & \multirow{3}{*}{$\begin{array}{c}(3) \\
p \text {-value } \\
\left(H_{0}: \text { Equality of Coeff. }\right)\end{array}$} \\
\hline & Coeffici & & \\
\hline & Ex. (Soviet Sector) & Ex. (Direct) & \\
\hline Years of Schooling '89 & $\begin{array}{l}-0.398 \\
(2.093)\end{array}$ & $\begin{array}{l}-0.538 \\
(0.673)\end{array}$ & 0.956 \\
\hline Share Entrepreneur ' 89 & $\begin{array}{c}0.017 \\
(0.160)\end{array}$ & $\begin{array}{c}0.033 \\
(0.046)\end{array}$ & 0.937 \\
\hline Share Unemployed '89 & $\begin{array}{l}-0.130 \\
(0.121)\end{array}$ & $\begin{array}{l}-0.036 \\
(0.031)\end{array}$ & 0.506 \\
\hline Sh. Employed in Agriculture '89 & $\begin{array}{r}-0.406^{*} \\
(0.238)\end{array}$ & $\begin{array}{l}0.151^{*} \\
(0.080)\end{array}$ & 0.059 \\
\hline Sh. Employed in Manufacturing '89 & $\begin{array}{c}0.877 \\
(0.800)\end{array}$ & $\begin{array}{l}-0.022 \\
(0.221)\end{array}$ & 0.347 \\
\hline Sh. Employed in Services ' 89 & $\begin{array}{c}0.447 \\
(0.554)\end{array}$ & $\begin{array}{l}-0.195 \\
(0.161)\end{array}$ & 0.334 \\
\hline Sh. Employed in Government '89 & $\begin{array}{l}-0.323 \\
(0.352)\end{array}$ & $\begin{array}{c}0.005 \\
(0.065)\end{array}$ & 0.392 \\
\hline
\end{tabular}

Notes: Part A of Appendix Table 4 presents results from ordinary least squares regressions of the outcome variable shown in the leftmost column on Share Housing Destroyed and the same controls as column 3 of Table 3. Each row represents an independent regression and we only report the coefficient estimates on the share of housing destruction in column 1. Column 2 gives the $p$-value of a $t$-test of the equality of the coefficient in column 1 to 0 . Part B presents results from ordinary least squares regressions of the outcome variable shown in the leftmost column on Share Expellees (Soviet Sector), the Share Expellees (Direct) and the same controls as column 3 of Table 3. Each row represents an independent regression and we only report the coefficient estimates on the shares of the two types of expellees in column 1 and column 2. Column 3 gives the $p$-value of a $t$-test of the equality of the coefficients in column 1 and 2 . In both Part A and B standard errors are given in parentheses and calculated using the Huber-White correction to correct for potential heteroscedasticity. 
Appendix Table 5: Placebo

\begin{tabular}{|c|c|c|c|c|c|c|}
\hline & $(1)$ & $(2)$ & $(3)$ & $(4)$ & $(5)$ & $(6)$ \\
\hline PANEL A: & \multicolumn{6}{|c|}{ Income '95/'89 (p.c., log) } \\
\hline & \multicolumn{3}{|c|}{$(\mathrm{OLS})$} & \multicolumn{3}{|c|}{$(\mathrm{IV})$} \\
\hline Share Expellees (Sov. S.) '61 & $\begin{array}{c}2.131^{* * *} \\
(0.701)\end{array}$ & $\begin{array}{c}2.150^{* * *} \\
(0.722)\end{array}$ & $\begin{array}{c}2.039 * * * \\
(0.557)\end{array}$ & $\begin{array}{l}3.422^{*} \\
(1.796)\end{array}$ & $\begin{array}{c}3.396^{*} \\
(1.774)\end{array}$ & $\begin{array}{l}2.943^{*} \\
(1.726)\end{array}$ \\
\hline Share Expellees (Direct) ' 61 & $\begin{array}{l}-0.092 \\
(0.149)\end{array}$ & $\begin{array}{l}-0.099 \\
(0.160)\end{array}$ & $\begin{array}{l}-0.043 \\
(0.154)\end{array}$ & $\begin{array}{l}-0.350 \\
(0.620)\end{array}$ & $\begin{array}{c}-0.371 \\
(0.656)\end{array}$ & $\begin{array}{l}-0.065 \\
(0.693)\end{array}$ \\
\hline Sh. Employed in Agricult. '89 & & $\begin{array}{c}0.047 \\
(0.192)\end{array}$ & $\begin{array}{l}-0.028 \\
(0.302)\end{array}$ & & $\begin{array}{c}0.139 \\
(0.270)\end{array}$ & $\begin{array}{l}-0.114 \\
(0.295)\end{array}$ \\
\hline Sh. Employed in Manufact. '89 & & & $\begin{array}{l}-0.197 \\
(0.250)\end{array}$ & & & $\begin{array}{l}-0.316 \\
(0.306)\end{array}$ \\
\hline Sh. Employed in Services '89 & & & $\begin{array}{c}0.240 \\
(0.251)\end{array}$ & & & $\begin{array}{c}0.121 \\
(0.331)\end{array}$ \\
\hline Sh. Employed in Governm.'89 & & & $\begin{array}{l}-0.452 \\
(0.426)\end{array}$ & & & $\begin{array}{l}-0.535 \\
(0.410)\end{array}$ \\
\hline $\mathrm{R}^{2}$ & 0.600 & 0.600 & 0.663 & 0.557 & 0.560 & 0.639 \\
\hline Instruments & - & - & - & $\begin{array}{l}\text { Housing } \\
\text { \& Rubble }\end{array}$ & $\begin{array}{l}\text { Housing } \\
\& \text { Rubble }\end{array}$ & $\begin{array}{l}\text { Housing } \\
\& \text { Rubble }\end{array}$ \\
\hline PANEL B: First Stage & & & & \multicolumn{3}{|c|}{ Share Expellees (Sov. Sector) '61 } \\
\hline Share Housing Destroyed ' 46 & & & & $\begin{array}{c}-0.020^{* * *} \\
(0.006)\end{array}$ & $\begin{array}{c}-0.021^{* * *} \\
(0.006)\end{array}$ & $\begin{array}{c}-0.020^{* * *} \\
(0.006)\end{array}$ \\
\hline Rubble '46 ( $\mathrm{m}^{3}$ p.c. $)$ & & & & $\begin{array}{c}0.002 \\
(0.015)\end{array}$ & $\begin{array}{c}0.001 \\
(0.015)\end{array}$ & $\begin{array}{c}-0.002 \\
(0.016)\end{array}$ \\
\hline $\mathrm{R}^{2}$ & & & & 0.920 & 0.922 & 0.931 \\
\hline PANEL C: First Stage & & & & \multicolumn{3}{|c|}{ Share Expellees (Direct) '61 } \\
\hline Share Housing Destroyed ' 46 & & & & $\begin{array}{c}-0.026 \\
(0.017)\end{array}$ & $\begin{array}{c}-0.026 \\
(0.017)\end{array}$ & $\begin{array}{c}-0.027 \\
(0.019)\end{array}$ \\
\hline Rubble '46 ( $\mathrm{m}^{3}$ p.c.) & & & & $\begin{array}{c}-0.107^{* *} \\
(0.046)\end{array}$ & $\begin{array}{c}-0.106^{* *} \\
(0.045)\end{array}$ & $\begin{array}{c}-0.104^{* *} \\
(0.051)\end{array}$ \\
\hline $\mathrm{R}^{2}$ & & & & 0.817 & 0.818 & 0.822 \\
\hline $\mathrm{N}$ & 70 & 70 & 70 & 70 & 70 & 70 \\
\hline Standard Region Level Controls & yes & yes & yes & yes & yes & yes \\
\hline
\end{tabular}

Notes: Panel A reports coefficient estimates from ordinary least squares regressions at the regional level in columns 1 through 3. Columns 4 through 6 report results from instrumental variable regressions. Standard errors are given in parentheses. Standard errors are calculated using the Huber-White correction to account for potential heteroscedasticity. In Panel A the dependent variable is the log of the ratio of mean per capita income in 1995 and 1989 . The main variables of interest are Share Expellees (Soviet Sector) '61 and Share Expellees (Direct) '61. In the specifications in columns 4 through 6 of Panel A we instrument for these variables with Share Housing Destroyed 46 and Rubble 46 ( $m^{3}$ p.c.). The corresponding first stage regressions are given in columns 4-6 of Panel B and C. All regressions control for a region's distance to the inner-German border, the log of mean per capita income in 1989 and the log of the ratio of mean per capita income in 1989 and 1985. All regressions include 10 state fixed effects. Coefficient estimates for these controls are not shown to save space. 
Appendix Table 6: Co-Movement with the Cycle

\begin{tabular}{lccc}
\hline \hline & $(1)$ & $(2)$ & $(3)$ \\
\hline & \multicolumn{1}{c}{ Income } & '89/'85 $(p . c ., \log )$ \\
\hline Share Expellees (Sov. S.) '61 & $1.892^{* * *}$ & $2.482^{* * *}$ & $2.637^{* * *}$ \\
& $(0.527)$ & $(0.845)$ & $(0.640)$ \\
Growth Beta & -0.007 & -0.006 & $-0.016^{* * *}$ \\
& $(0.008)$ & $(0.008)$ & $(0.005)$ \\
Income 1989 (p.c., log) & $-0.184^{* * *}$ & $-0.210^{* * *}$ & $-0.209^{* * *}$ \\
& $(0.060)$ & $(0.059)$ & $(0.036)$ \\
Distance East (100km) & $0.009^{* *}$ & $0.011^{* * *}$ & $0.012^{* * *}$ \\
& $(0.004)$ & $(0.004)$ & $(0.004)$ \\
Income '89/'85 (p.c., log) & $-0.392^{* * *}$ & $-0.380^{* * *}$ & $-0.551^{* * *}$ \\
& $(0.075)$ & $(0.081)$ & $(0.088)$ \\
$\mathrm{R}^{2}$ & 0.607 & 0.595 & 0.771 \\
$\mathrm{~N}$ & 70 & 70 & 70 \\
\hline
\end{tabular}

Notes: The table reports coefficient estimates from regressions at the regional level. Column 1 shows results from an ordinary least squares regression (corresponding to Column 2 of Panel A of Table 3). Columns 2 and 3 show results from instrumental variable regressions (corresponding to Column 3 of Panel A of Table 3). The control variables correspond to the respective regressions in Panel A of Table 3. Additionally to the corresponding regressions in Panel A of Table 3 we include the region level 'Beta'. This is the coefficient of region-specific regressions of regional growth (measured as difference in log income) between the years 1982, 1985, 1986, 1987 and 1989, on Germany-wide growth (measured as difference in log income) during this periods. Robust standard errors are given in parentheses. Column 3 weights the observations with the inverse of the standard error of the estimate of 'Beta'. 
Appendix Table 7: Social Ties and Firm Investment (Share)

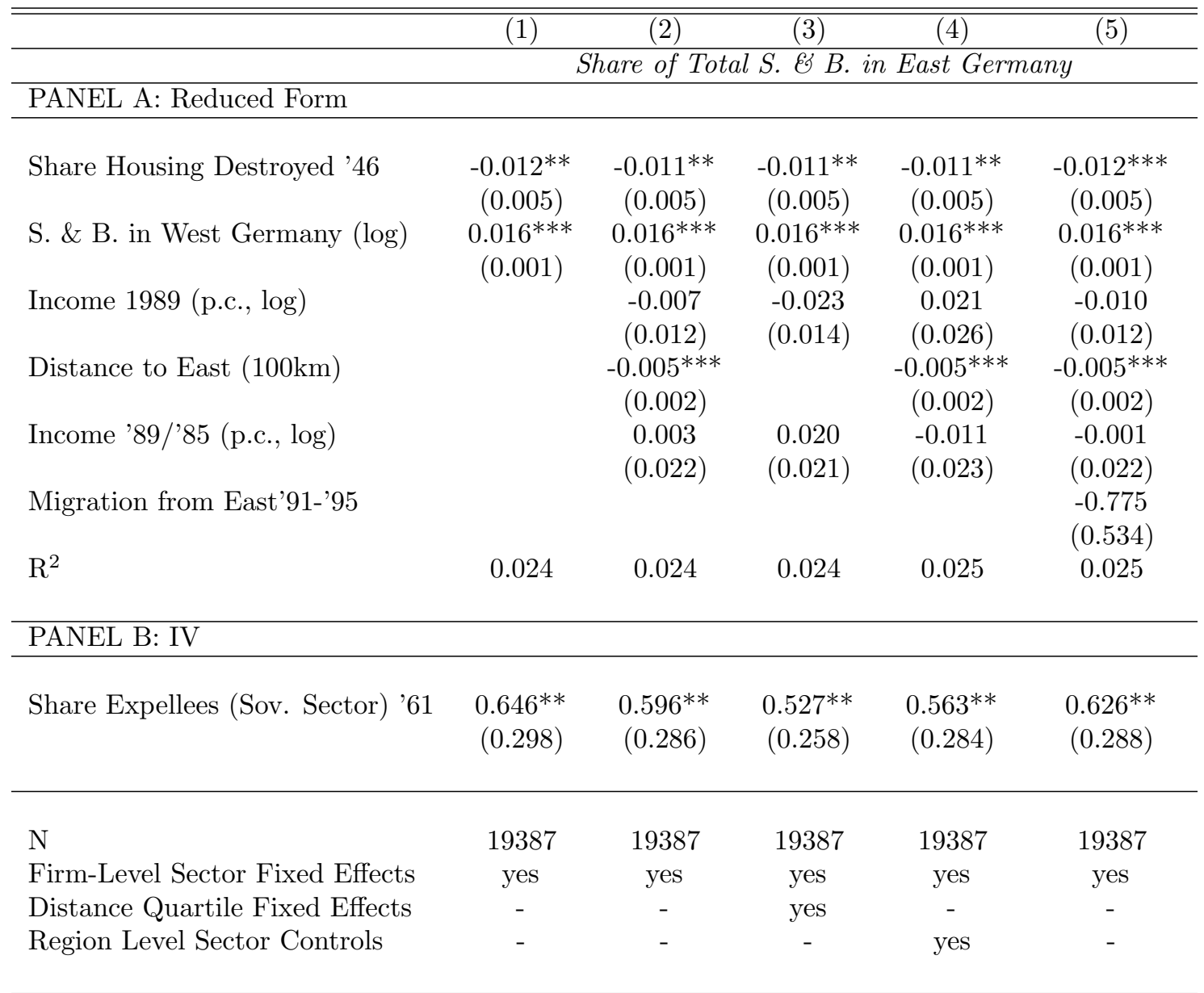

Notes: All Panels report firm-level regression results using our sample of firms which are headquartered in West Germany. Standard errors are clustered at the district level to account for likely spatial correlation. Panel A reports results from firm-level ordinary least squares regressions. Panel B reports results of firm-level instrumental variables regressions. The main variable of interest in these specifications is Share Expellees (Soviet Sector) '61. We instrument for this variable with Share Housing Destroyed '46. Corresponding first stage results at the regional level are shown in Table 2. The dependent variable in both panels is the number of a firm's subsidiaries and branches located in East Germany relative to the number of its subsidiaries and branches in all of Germany. All regressions include 10 state fixed effects and 4 firm-level sector fixed effects (agriculture, manufacturing, services, government). We control for distance to the inner-German border at the district level. Log of per capita income in 1989 and $\log$ of the ratio of per capita income in 1989 and 1985 are regional level controls. Column 3 controls for 4 distance dummies, corresponding to quartiles of the distance measure. Column 4 controls for the share of a region's 1989 population working in agriculture, manufacturing, services and government, respectively. The specification in column 5 controls for the share of the region's population who are migrants arriving from East Germany between 1991 and 1995. All specifications in Panels B-E include the same controls as the specification in Panel A, which we do not report to save space. 
Appendix Table 8: Sector Specific Effects

\begin{tabular}{lcc}
\hline \hline & $\begin{array}{c}\text { S. } \text { G B. in East } \\
\text { Germany (Dummy) }\end{array}$ & $\mathrm{N}$ \\
\hline Expellees '61 × Agriculture & 3.302 & \\
& $(4.308)$ & 307 \\
Expellees '61 × Services & $2.121^{* *}$ & \\
& $(1.012)$ & 15500 \\
Expellees '61 × Manufacturing & 0.024 & 3219 \\
& $(1.749)$ & \\
Expellees '61 × Government & -2.579 & \\
& $(2.432)$ & \\
$\mathrm{N}$ & 19387 & \\
Instrument & Housing $\times$ Sector & \\
\end{tabular}

Notes: The table reports coefficient estimates from a firm-level instrumental variables regression using our sample of firms which are headquartered in West Germany. Standard errors are given in parentheses. Standard errors are clustered at the district level to account for likely spatial correlation. The main variable of interest is the interaction of 4 exhaustive sectoral fixed effects (agriculture, manufacturing, services and government) with Share Expellees (Soviet Sector) '61. (The main effect of Share Expellees (Soviet Sector) '61 is hence not included.) We instrument with the interaction of the sectoral fixed effects and Share Housing Destroyed 46. The dependent variable is a dummy indicating whether a firm has a subsidiary or branch in East Germany. The regression includes 10 state fixed effects and the 4 firm-level sector fixed effects (agriculture, manufacturing, services, government). It also includes the same controls as the specifications in column 2 of Table 5 . We do not report these coefficients on these controls to save space. The second column shows the number of firms in each sector. 
Appendix Table 9: Robustness

\begin{tabular}{|c|c|c|c|c|c|c|c|}
\hline & $\overline{(1)}$ & $\overline{(\overline{(2)}}$ & 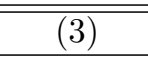 & $\overline{(4)}$ & $\overline{\overline{(5)}}$ & 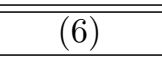 & 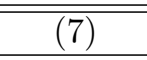 \\
\hline PANEL A: Full Sample & & & Income's & /'89(log) & & & \\
\hline Ties to Relatives '91 & $\begin{array}{c}0.058^{* * *} \\
(0.021)\end{array}$ & $\begin{array}{c}0.061^{* * *} \\
(0.021)\end{array}$ & $\begin{array}{c}0.053^{* * *} \\
(0.019)\end{array}$ & $\begin{array}{c}0.058^{* * *} \\
(0.021)\end{array}$ & $\begin{array}{c}0.058^{* * *} \\
(0.021)\end{array}$ & $\begin{array}{c}0.068^{* * *} \\
(0.021)\end{array}$ & $\begin{array}{c}0.064^{* * *} \\
(0.019)\end{array}$ \\
\hline Sector: Government '89 & & $\begin{array}{c}0.075^{* *} \\
(0.029)\end{array}$ & & & & & $\begin{array}{c}0.026 \\
(0.033)\end{array}$ \\
\hline Years of Education '89 & & & $\begin{array}{c}-0.044 \\
(0.071)\end{array}$ & & & & $\begin{array}{l}-0.044 \\
(0.071)\end{array}$ \\
\hline$\left(\right.$ Years of Education '89) ${ }^{2}$ & & & $\begin{array}{c}0.003 \\
(0.003)\end{array}$ & & & & $\begin{array}{c}0.003 \\
(0.003)\end{array}$ \\
\hline Occupation: Entrepreneur '89 & & & & $\begin{array}{c}0.043 \\
(0.067)\end{array}$ & & & $\begin{array}{c}0.029 \\
(0.061)\end{array}$ \\
\hline Transfers to Relatives '90-'95 (log) & & & & & $\begin{array}{c}0.006 \\
(0.008)\end{array}$ & & $\begin{array}{c}0.002 \\
(0.008)\end{array}$ \\
\hline Lived in East Germany & & & & & & $\begin{array}{l}-0.057 \\
(0.045)\end{array}$ & $\begin{array}{l}-0.062 \\
(0.043)\end{array}$ \\
\hline $\mathrm{R}^{2}$ & 0.274 & 0.277 & 0.305 & 0.274 & 0.274 & 0.275 & 0.307 \\
\hline $\mathrm{N}$ & 1857 & 1857 & 1857 & 1857 & 1857 & 1857 & 1857 \\
\hline PANEL B: Restricted Sample & & & Income'? & /'89(log) & & & \\
\hline Ties to Relatives '91 & $\begin{array}{c}0.069^{* * *} \\
(0.023)\end{array}$ & $\begin{array}{c}0.071^{* * *} \\
(0.023)\end{array}$ & $\begin{array}{c}0.061^{* * *} \\
(0.021)\end{array}$ & $\begin{array}{c}0.069^{* * *} \\
(0.023)\end{array}$ & $\begin{array}{c}0.067^{* * *} \\
(0.023)\end{array}$ & $\begin{array}{c}0.077^{* * *} \\
(0.024)\end{array}$ & $\begin{array}{c}0.071^{* * *} \\
(0.021)\end{array}$ \\
\hline $\mathrm{R}^{2}$ & 0.281 & 0.284 & 0.318 & 0.281 & 0.283 & 0.282 & 0.321 \\
\hline $\mathrm{N}$ & 1533 & 1533 & 1533 & 1533 & 1533 & 1533 & 1533 \\
\hline Household Level Controls & yes & yes & yes & yes & yes & yes & yes \\
\hline
\end{tabular}

Notes: The table reports coefficient estimates from weighted least squares regressions at the household level. The inverse of the sampling probability provided by SOEP is used as weights. Standard errors, clustered at the region level to account for spatial correlation, are given in parentheses. The dependent variable in all regressions is the log of the ratio of household income in 1995 and 1989 . Column 1 replicates the results from the household level regression in column 5 in Table 6. All specifications include, additional to the shown covariates, the same controls as the specification in column 5 in Table 6. Panel A reports results using the full sample. In Panel B we replicate the regressions from Panel A using a restricted sample. In this sample we exclude households who did not have operational assets in 1989, but report to have such assets in 1995 as well as all households which report to have income from renting out property in 1995. For expositional clarity we only report results for the coefficient of interest. See data appendix for details on the construction of our variables. 
Appendix Table 10: Conditional Differences between Households with and without Ties

\begin{tabular}{lcl}
\hline \hline & Coefficient (St. Err) on & \\
Outcome Variable & Ties to Relatives '91 & $N$ \\
\hline
\end{tabular}

PANEL A: Socio-Economic Characteristics

Education

Years of Education '89

$0.145(0.100) \quad 1857$

Occupational Status

Not Employed '89

In Education/Military Service '89

$0.002(0.013) \quad 1857$

Pensioner '89

Worker '89

Entrepreneur '89

White Collar ' 89

$-0.002(0.005) \quad 1857$

$0.009(0.016) \quad 1857$

$0.005(0.023) \quad 1857$

Civil Servant '89

$-0.005(0.005) \quad 1857$

$0.012(0.022) \quad 1857$

$-0.021(0.013) \quad 1857$

Industry Sector

Agriculture '89

Manufacturing '89

$-0.007(0.005) \quad 1857$

Services '89

Government '89

$0.016(0.021) \quad 1857$

$0.020(0.017) \quad 1857$

$-0.030 *(0.018) \quad 1857$

Sources of Income

Entrepreneurial Activity '89 (log) $\quad 0.056(0.118) \quad 1857$

Employment '89 (log) $\quad 0.134(0.169) \quad 1857$

Profit Share '89 (log) $\quad 0.053(0.095) \quad 1857$

Capital (Financial Securities) '89 (log) $\quad 0.024(0.063) \quad 1857$

$\begin{array}{lll}\text { Operating Assets '89 (D) } & 0.004(0.011) & 1857\end{array}$

Affiliations

Union Membership '89

Membership in a Professional Association '89

$-0.035(0.026) \quad 2008$

$-0.010(0.017) \quad 1857$

\section{PANEL B: Transfers}

Transfers from Relatives '89 (log)

Transfers to Relatives '89 (log)

Transfers from Relatives '90-'95 (log)

Transfers to Relatives '90-'95 (log)

$\begin{array}{cc}0.001(0.065) & 1857 \\ 0.238^{* * *}(0.063) & 1857 \\ 0.117(0.084) & 1857 \\ 0.329^{* * *}(0.121) & 1857\end{array}$

PANEL C: Expectations

Concern about Aggregate Economic Development '90

$\begin{array}{ll}0.032(0.036) & 1847 \\ 0.033(0.037) & 1846 \\ 0.016(0.041) & 1188\end{array}$

Concern about Individual Job Security '90

Notes: The table shows results from ordinary least squares regressions of the outcome variable shown in the leftmost column on Ties to Relatives ' 91 and the same controls as column 4 of Table 6. Each row represents an independent regression and we only report the coefficient estimate and standard error on Ties to Relatives '91. Standard errors are given in parentheses and calculated using the Huber-White correction to correct for potential heteroscedasticity. The last column shows the sample size. In Panel B the dependent variable Transfers to Relatives ' 89 is the yearly amount of "payments of financial support to relatives" (excluding parents, parents-in-law, children, children-in-law, separated/divorced partner). Transfers to Relatives '90' 95 is the sum of this variable for the years 1990, 1991, 1993, and 1995 (the question was not asked in the years 1992 and 1994). Transfers from Relatives '89 is the average monthly household income of support payments from persons who do not live in the same household. Transfers from Relatives '90-'95 is the sum of monthly support payments for the years 1990, 1991, 1993, and 1995. The dependent variables in Panel $\mathrm{C}$ are responses to the question "What about the folbpwing areas: Do they worry you?". The responses are coded on a scale from 1 to 3 in which 1 represents "a major" concern and 3 represents "no concern". 
Appendix Table 11: East Germany

\begin{tabular}{|c|c|c|c|c|c|c|}
\hline & $(1)$ & $(2)$ & $(3)$ & $(4)$ & $(5)$ & $(6)$ \\
\hline & \multicolumn{6}{|c|}{ Income $(\log , S O E P)$} \\
\hline & 1990 & 1991 & 1992 & 1993 & 1994 & 1995 \\
\hline \multirow[t]{2}{*}{ Ties to Relatives '91 } & 0.039 & 0.041 & $0.072^{*}$ & 0.040 & 0.063 & 0.046 \\
\hline & $(0.029)$ & $(0.041)$ & $(0.039)$ & $(0.037)$ & $(0.040)$ & $(0.045)$ \\
\hline \multirow{2}{*}{ Income '89 (p.c., log, SOEP) } & $0.282^{* * *}$ & $0.164^{* * *}$ & $0.187^{* * *}$ & $0.150^{* * *}$ & $0.191^{* * *}$ & $0.164^{* * *}$ \\
\hline & $(0.051)$ & $(0.039)$ & $(0.036)$ & $(0.034)$ & $(0.032)$ & $(0.029)$ \\
\hline \multirow[t]{2}{*}{ Gender } & -0.020 & -0.051 & -0.041 & $-0.065^{* *}$ & $-0.053^{*}$ & $-0.070^{* *}$ \\
\hline & $(0.036)$ & $(0.037)$ & $(0.030)$ & $(0.028)$ & $(0.027)$ & $(0.031)$ \\
\hline \multirow[t]{2}{*}{ Age '90 } & $0.049 * * *$ & $0.038^{* * *}$ & $0.024^{* * *}$ & $0.024^{* * *}$ & $0.014^{* * *}$ & $0.012^{* * *}$ \\
\hline & $(0.005)$ & $(0.005)$ & $(0.004)$ & $(0.006)$ & $(0.005)$ & $(0.004)$ \\
\hline \multirow[t]{2}{*}{$(\text { Age ' } 90)^{2}$} & $-0.001^{* * *}$ & $-0.000^{* * *}$ & $-0.000^{* * *}$ & $-0.000^{* * *}$ & $-0.000^{* * *}$ & $-0.000^{* * *}$ \\
\hline & $(0.000)$ & $(0.000)$ & $(0.000)$ & $(0.000)$ & $(0.000)$ & $(0.000)$ \\
\hline $\mathrm{R}^{2}$ & 0.463 & 0.308 & 0.274 & 0.282 & 0.252 & 0.247 \\
\hline $\mathrm{N}$ & 1359 & 1359 & 1359 & 1359 & 1359 & 1359 \\
\hline
\end{tabular}

Notes: The table reports coefficient estimates from weighted least squares regressions at the household level. It uses the sample of households located in East Germany in both 1990 and 1995. The inverse of the sampling probability provided by SOEP is used as weights. Standard errors, clustered at the regional level to correct for spatial correlation, are given in parentheses. The dependent variable is the log of household income in the specified year. The explanatory variable of interest is a dummy indicating ties to relatives in West Germany. All specifications include a full set of region fixed effects. See data appendix for details. 


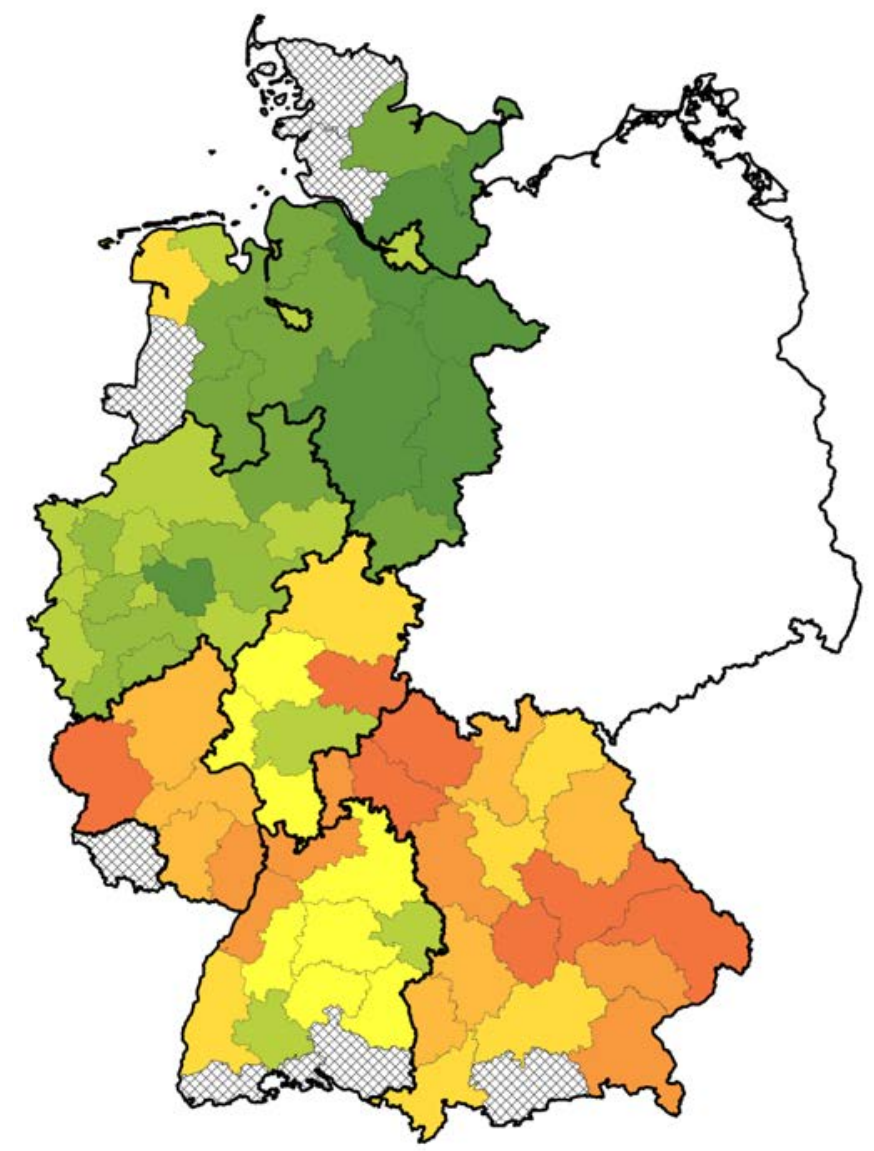

Notes:The figure presents the level of Share Expellees (Soviet Sector) '61 in West German regions. The 10 colors refer to 10 centiles (10th, 20th, 30th and so on) of expellee settlement, with red indicating those regions with least settlement and green indicating regions with most settlement. The the cut-off values for those centiles of Share Expellees (Soviet Sector) '61 are 0.029, 0.032, 0.034, $0.036,0.043,0.053,0.058,0.067,0.077$, respectively. Grey areas indicate regions for which we do not have full data (typically missing war destruction data).

\section{Appendix Figure 2: Share Ties to Relatives and Share Expellees}

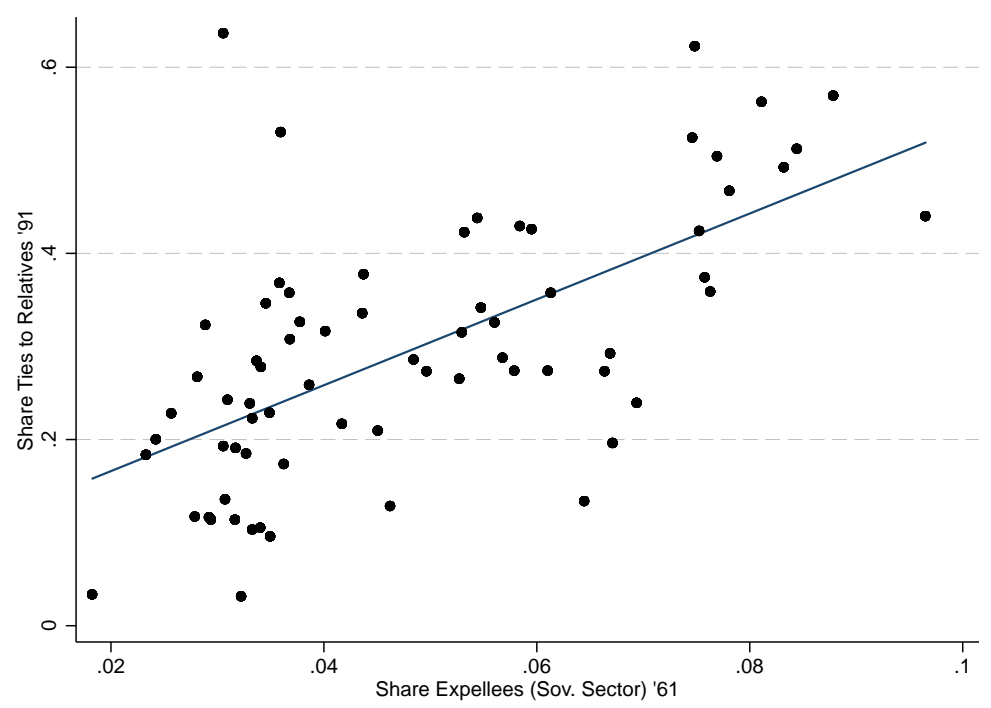

Notes: The figure is a scatterplot of our two measures of social ties, Share Expellees (Soviet Sector) '61 and Share Ties to Relatives '91. The solid line depicts the fitted regression line from an ordinary least squares regression of Share Ties to Relatives '91 on Share Expellees (Soviet Sector) '61 and a constant. The coefficient estimate on Share Expellees (Soviet Sector) '61 is 3.41 (s.e.=0.54) and significant at the $1 \%$ level. (Standard errors calculated using the Huber-White correction to account for potential heteroscedasticity.) 


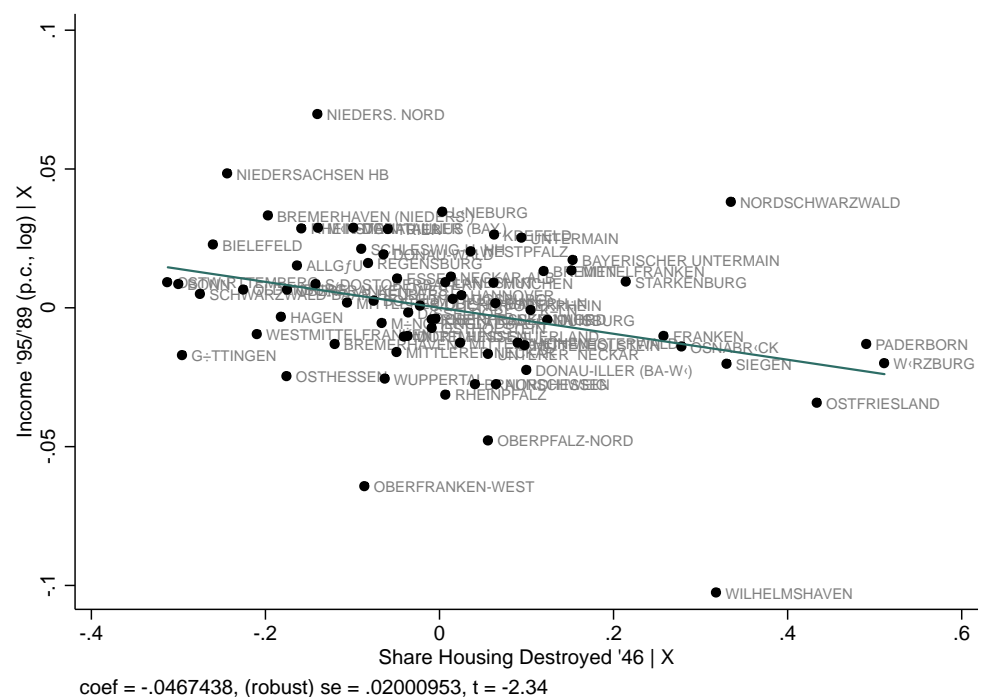

Notes: The figure is a conditional scatterplot of the log of the ratio of per capita income in 1995 and 1989 and Share Housing Destroyed '46. The reduced form regression corresponding to this plot, presented in column 2 of Panel C of Table 2, controls for distance to the inner-German border, the log of per capita income in 1989, the log of the ratio of per capita income in 1989 and 1985 and a full set of state fixed effects. The solid line depicts the estimated linear relation between the log of the ratio of per capita income in 1995 and 1989 and share housing destroyed. The coefficient estimate is -0.048 (s.e.=0.020) and significant at the $5 \%$ level. (Standard errors calculated using the Huber-White correction to account for potential heteroscedasticity.)

Appendix Figure 4: Estimated Relationship between Social and Economic Spill-Over

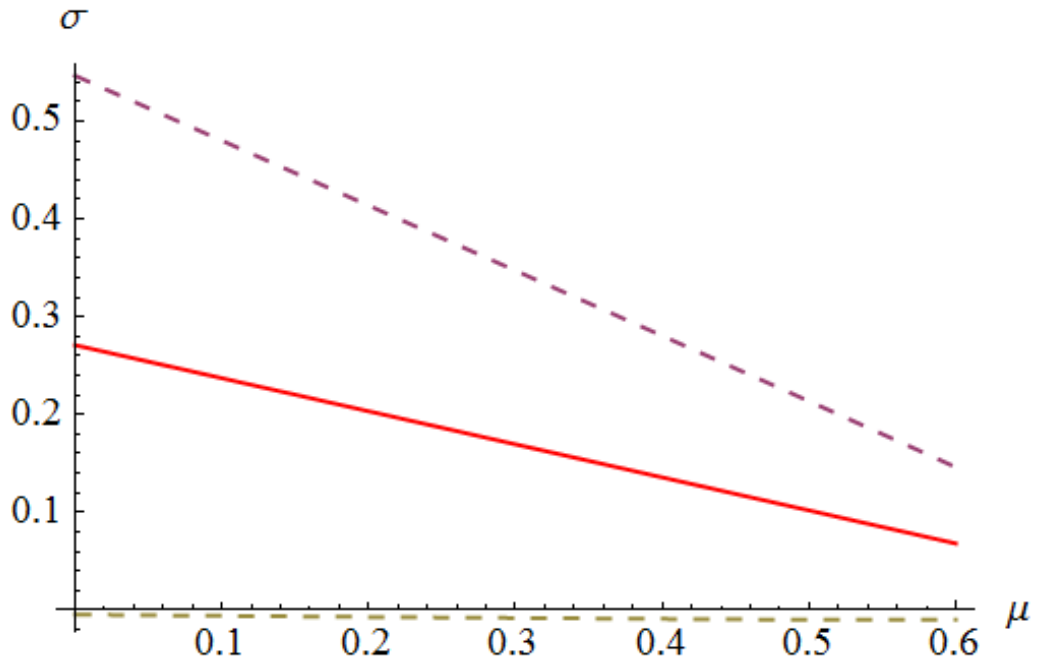

Notes: This figure depicts the estimates for $\sigma$ (the effect of the share of the region population who have ties to the East on the income of an individual household who itself may or may not have such ties) and $\mu$ (the effect of average income growth a given region on the income of an individual household) implied by equation (5), the estimate of $\alpha$ from column 5 and the estimate of $\beta$ from column 3 of Table 6 . The dashed lines trace out the $90 \%$ confidence interval which is calculated by bootstrapping standard errors across the two regressions. The bootstrapped standard errors were calculated by performing 500 iterations of the following procedure: we sampled 70 regions (with replacement) in the region level dataset and ran the specification of column 5 of Table 6 ; we sampled the household data from the same regions (with replacement) and ran the specification of column 3 of Table 6 . From the two $1 \times 500$ vectors of coefficient estimates we calculated the bootstrapped variance-covariance matrix. 